\title{
A279.9
}

USDA UI Ag8

of Agrículture

Agricultural

Research

Service

Conservation

Research

Report No. 45

December 2001

\section{Eighty Years of}

Vegetation and Landscape

Changes in the Northern

Great Plains

\section{A Photographic Record}

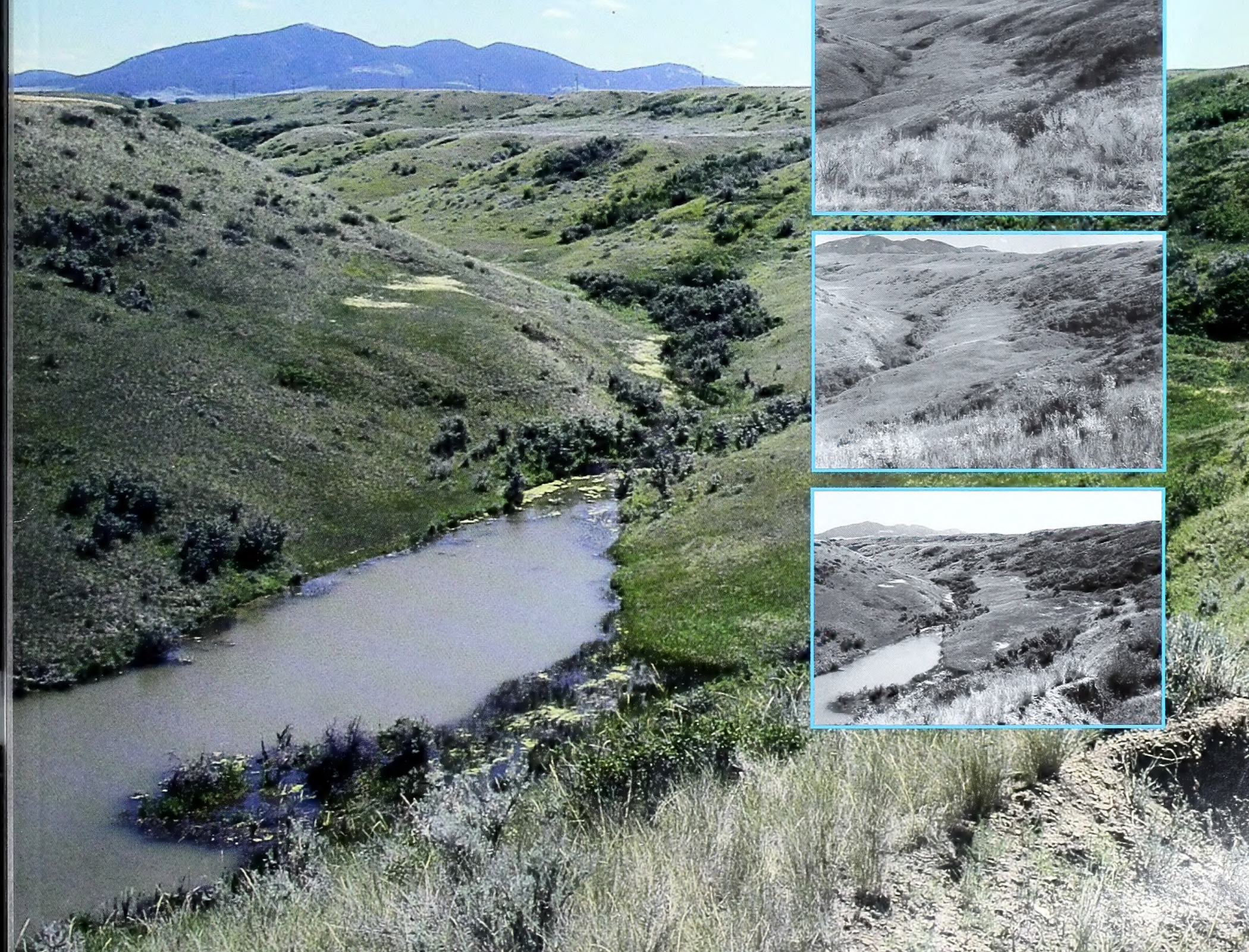





\section{Historic, archived document}

Do not assume content reflects current scientific knowledge, policies, or practices. 

United States

Department

of Agriculture

Agricultural

Research

Service

Conservation

Research

Report No. 45

December 2001

\section{Eighty Years of Vegetation and Landscape Changes in the Northern Great Plains} A Photographic Record

K.D. Klement, R.K. Heitschmidt, and C. E. Kay

Klement is a rangeland scientist and Heitschmidt is a supervisory rangeland scientist, USDA Agricultural Research Service, Fort Keogh Livestock and Range Research Laboratory, Miles City, Montana. Kay is an adjunct assistant professor, Department of Political Science, Utah State University, Logan. 
Klement, K.D., R.K. Heitschmidt, and C.E. Kay. 2001. Eighty Years of Vegetation and Landscape Changes in the Northern Great Plains: A Photographic Record. U.S. Department of Agriculture, Agricultural Research Service, Conservation Research Report No. 45.

This publication is a photographic record of vegetation and landscape changes that have occurred at selected sites in the Northern Great Plains over the past 80 to 90 years. Based on photographic and written records, the authors found few changes had taken place other than (1) a general increase in the density and cover of woody plant species, particularly Ponderosa pine; (2) those resulting from direct human intervention, such as tillage, haying, and road construction; and (3) a general increase in nonindigenous species, particularly yellow sweet clover and created wheatgrass, as they escape from roadside restoration projects and agronomic plantings. Otherwise, the changes are subtle. Audiences for the publication include researchers, naturalists, land managers, policy makers, and the general public.

Keywords:

forbs, grasses, landscape, Northern Great Plains, plant species composition, shrubs, trees.

While supplies last, single copies of this publication may be obtained at no cost from USDA, Agricultural Research Service, Fort Keogh Livestock \& Range Research Laboratory, RR 1, Box 2021, Miles City, MT 59301.

Copies of this publication may be purchased from the $\mathrm{Na}$ tional Technical Information Service, 5285 Port Royal Road, Springfield, VA 22161; telephone (703) 605-6000.

The U.S. Department of Agriculture (USDA) prohibits discrimination in all its programs and activities on the basis of race, color, national origin, sex, religion, age, disability, political beliefs, sexual orientation, or marital or family status. (Not all prohibited bases apply to all programs.) Persons with disabilities who require alternative means for communication of program information (Braille, large print, audiotape, etc.) should contact USDA's TARGET Center at (202) 720-2600 (voice and TDD).

To file a complaint of discrimination, write USDA, Office of Civil Rights, Room 326-W, Whitten Building, 1400 Independence Avenue, SW, Washington, D.C. 20250-9410 or call (202) 720-5964 (voice and TDD). USDA is an equal opportunity provider and employer. 
Photographs and Descriptions

Montana

Danvers

Grassrange

Lewistown

Roundup

Valentine

Nebraska

Crawford

Long Pine

North Dakota

Fryburg

South Dakota

Belle Fourche

Belvidere

Custer State Park

Kadoka

Newell

Rumford 59

Spearfish 61

White River 67

Wyoming

Buffalo 69

Casper 71

Cody

Crazy Woman Creek

Story

Thermopolis

\section{Appendix 1.}

Plant Species, by Genus and Species and 



\section{Introduction}

Shifts in the composition of plant species are often linked to changes in the structure and function of ecological systems. But detecting such shifts in relatively undisturbed natural systems, such as rangelands and forests, is often difficult because changes occur very slowly and therefore are quite subtle. Often, changes aren't recognized because substantial change seldom occurs within a single human generation; rather, readily detectable change usually requires the span of several generations.

This publication is an attempt to provide researchers, naturalists, land managers, policy makers, and the general public with a new awareness of and appreciation for the subtle, yet real changes that have occurred over the past 80 to 90 years in the Northern Great Plains. We recorded the changes by repeating landscape photographs, which we augment with descriptions derived from on-site visits. The challenge to us authors, as well as our readers, revolves around how we might use the information presented here as a means for improving land stewardship.

The earliest photographs were taken by Dr. Homer Shantz, University of Arizona, from July 14, 1908 to September 1, 1937.

The second set of photos was taken of the original sites from June 13, 1958 to August 18, 1960. Shantz took a portion of these before he died in 1958 while on the road rephotographing the sites. He was accompanied on that trip by Dr. Walter S. Phillips, University of Arizona, who completed the repeat photography task in 1959, with the assistance of University of Arizona student Freeman Smith (now Dr. Freeman Smith, Colorado State University), and in 1960 in the company of his wife, Thelma K. Phillips.

The 1998 photographs were taken from July 21 to August 5, 1998, by Dr. Charles Kay, Utah State University.

Sites were again visited during the summer of 1999 by Keith Klement, U.S. Department of Agriculture, Agricultural Research Service, Fort Keogh Livestock and Range Research Laboratory, Miles City, Montana.

The original photographs, first retakes, and associated site descriptions were published by Phillips in 1963 in Photographic Documentation: Vegetational Changes in Northern Great Plains. A history of the two earlier photographic expeditions is contained in that publication.

The current publication includes repeat photographs from 42 of Shantz's 81 original sites. We limited our sites to rangelands. For most sites, four photographs are reproduced: (1) Shantz's black and white original, (2) the 1958-1960 black and white retake, (3) a 1998 black and white retake, and (4) a 1998 color retake. 
Under Location, we include county, state, section (Sec.), range (R.), township (T.), and GPS-UTM coordinates $( \pm 250 \mathrm{~m})$. The combination of letters and numbers following the date of each photograph refers to filing systems for the negatives of Shantz (original photograph), Phillips (first retake), or Kay (second retake). Shantz's and Phillips' original negatives are stored at the University of Arizona herbarium, in Tucson. Kay currently maintains his negatives, which he intends to leave to the Utah State University library, in Logan, upon his retirement.

The description provided in First Retake and Description is quoted from Phillips' publication, except we removed taxonomic authorities from scientific names and deleted references to other photographs. Each taxonomic Description following the head Second Retake is based on site visits by Klement, a highly experienced taxonomist. Dominant plant genera and species under Description are listed in order of their estimated relative abundance.

It is refreshing to review the photographs and conclude that the general ecological condition of the lands appears to have changed little over the past 75-plus years, with three exceptions. The first exception is that the density and cover of woody plants appear to have increased, particularly with respect to the Ponderosa pine. The second exception concerns changes in plant community structure and species composition due to human intervention (tillage, haying, and road construction, for example). And the third exception is those instances where nonindigenous species, particularly yellow sweet clover and crested wheatgrass, have invaded sites by escaping from nearby roadside restoration projects and agronomic plantings. Otherwise, the changes seem subtle. 



\section{Original Photograph}

September 18, 1917.

Shantz P-1-1917.

Facing west-northwest.

\section{First Retake and Description}

June 30, 1959.

W.S.P., H-2-1959.

Looking WNW the original vegetation is

Bouteloua spp. and Koeleria cristata. Carex filifolia is abundant in flat areas. Shrub in grass is Artemisia frigida. Shepherdia canadensis is a common shrub on the hillsides and bottomlands. Erosion not evident. Trees in creek bottom are better developed in later picture (from Phillips 1963, p. 23).
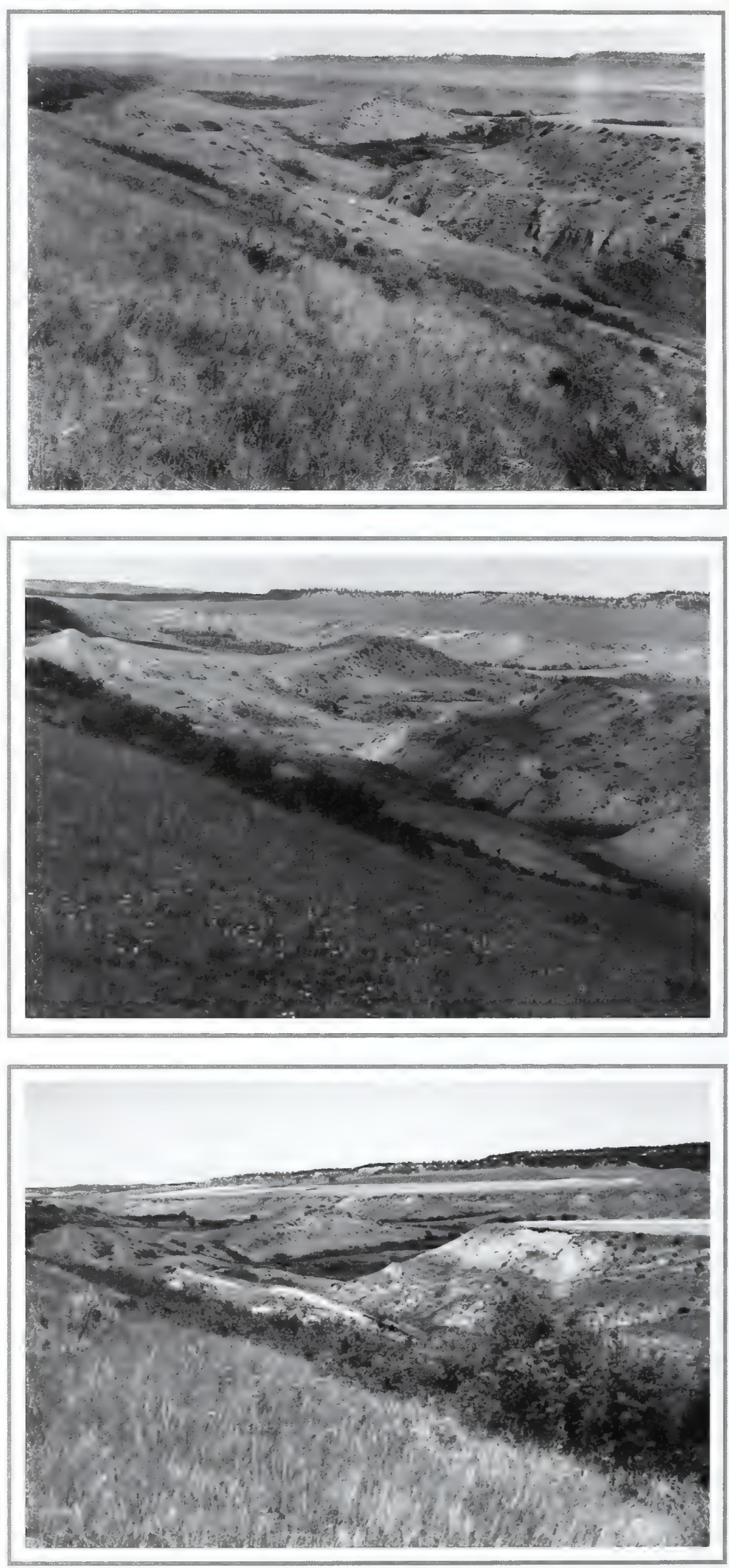


\section{Danvers, Montana}

\section{Location}

Fergus Co., MT; Sec. 2, R. 16 E., T. 17 N.; GPS-UTM 5234960 N, 602195 E.

About 20 miles northwest of Lewistown.

From Lewistown, Montana, travel north on U.S. Highway 191 about 9 miles to Montana Highway 81. Turn left (west) onto Highway 81 and continue about 12 miles. Near this point is a left turnoff leading south to Danvers and a right turnoff leading north onto a private two-track road. Turn right and travel about 1 mile. The photopoint is about 75 yards north-northeast of cornerpost overlooking Warm Spring Creek and its drainages.

\section{Description}

August 11, 1999

\section{Upland}

Grasses. Bouteloua gracilis, Koeleria pyramidata, Agropyron smithii, Stipa comata, Bouteloua cutipendula, Agropyron spicatum

Forbs. Liatris punctata, Achillea millefolium, Psoralea tenuiflora, Solidago spp.

\section{Ridgetops}

Shrubs and Trees. Artemisia frigida, Gutierrezia sarothrae

\section{Side Slopes}

Shrubs and Trees. Rhus trilobata, Prunus virginiana, Shepherdia argentea, Juniperus scopulorum, Amelanchier alnifolia, Artemisia cana

\section{Lowland}

Grasses. Agropyron smithii, Koeleria pyramidata, Stipa viridula, Poa pratensis, Agropyron trachycaulum, Spartina pectinata

Forbs. Achillea millefolium, Artemisia ludoviciana, Solidago spp.

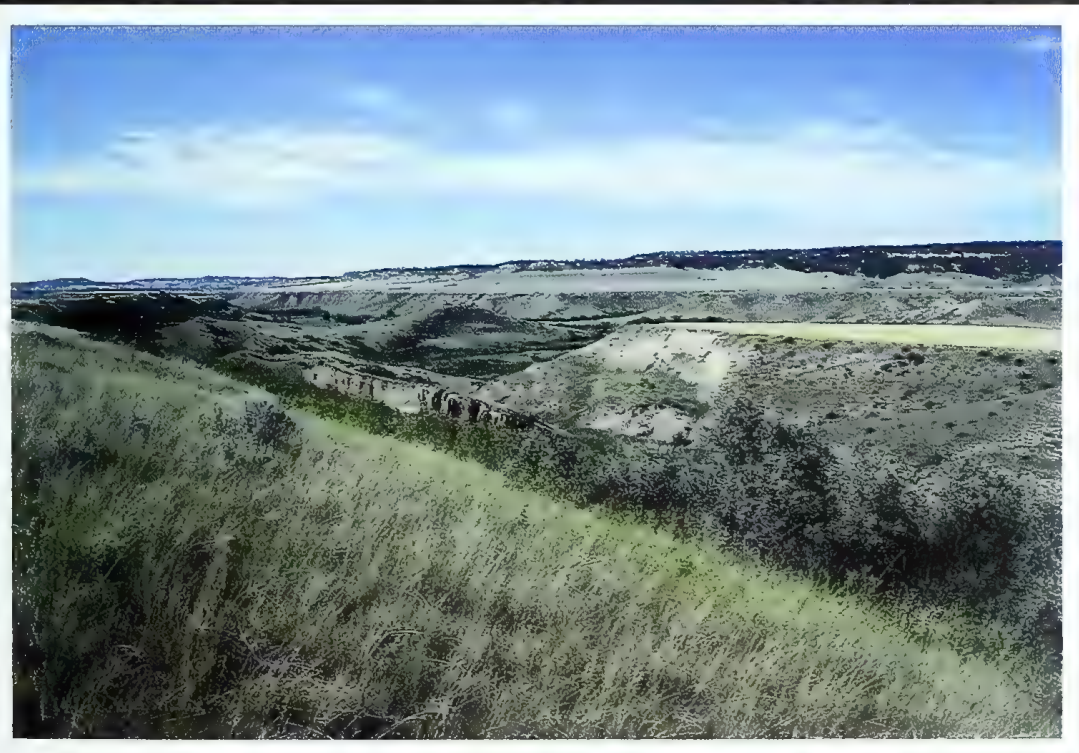

Shrubs and Trees. Salix exigua, Shepherdia argentea, Rosa woodsii, Symphoricarpos occidentalis, Populus deltoides, Populus trichocarpa, Populus angustifolia, Juniperus scopulorum

\section{Synopsis}

During the span of 82 years, shrubs have increased in density and grown in height and diameter along the ridges, ridgetops, and creek bottom. Pinus ponderosa has increased along the distant ridge since 1917. In the 1998 photo, Melilotus officinalis has invaded the uplands. The Shepherdia canadensis listed by Phillips as common on hillsides was identified as Shepherdia argentea in 1999. A wheat pasture occupies the plateau in the center right of the 1998 picture. A soil slump is present just below the ridge on the center plateau in 1959. This slump is even more apparent in 1998. Near the center of the 1998 photo, just below the shrub line, is a second soil slump. This slump has increased in size since first being photographed in 1959. Overall, this series of photographs shows a general increase in shrubs, trees, and vegetative cover, with the exception of the soil slumps. 


\section{Original Photograph}

September 18, 1917.

Shantz O-8-1917.

Facing east.

\section{First Retake and Description}

June 30, 1959.

W.S.P., H-9-1959.

Looking up a side creek bottom from Judith

River. Andropogon

scoparius was abundant in the original picture but very rare in the retake. Shepherdia canadensis along creek much increased (from Phillips 1963, p. 25).

\section{Second Retake}

July 21, 1998.

Kay-4326-35.
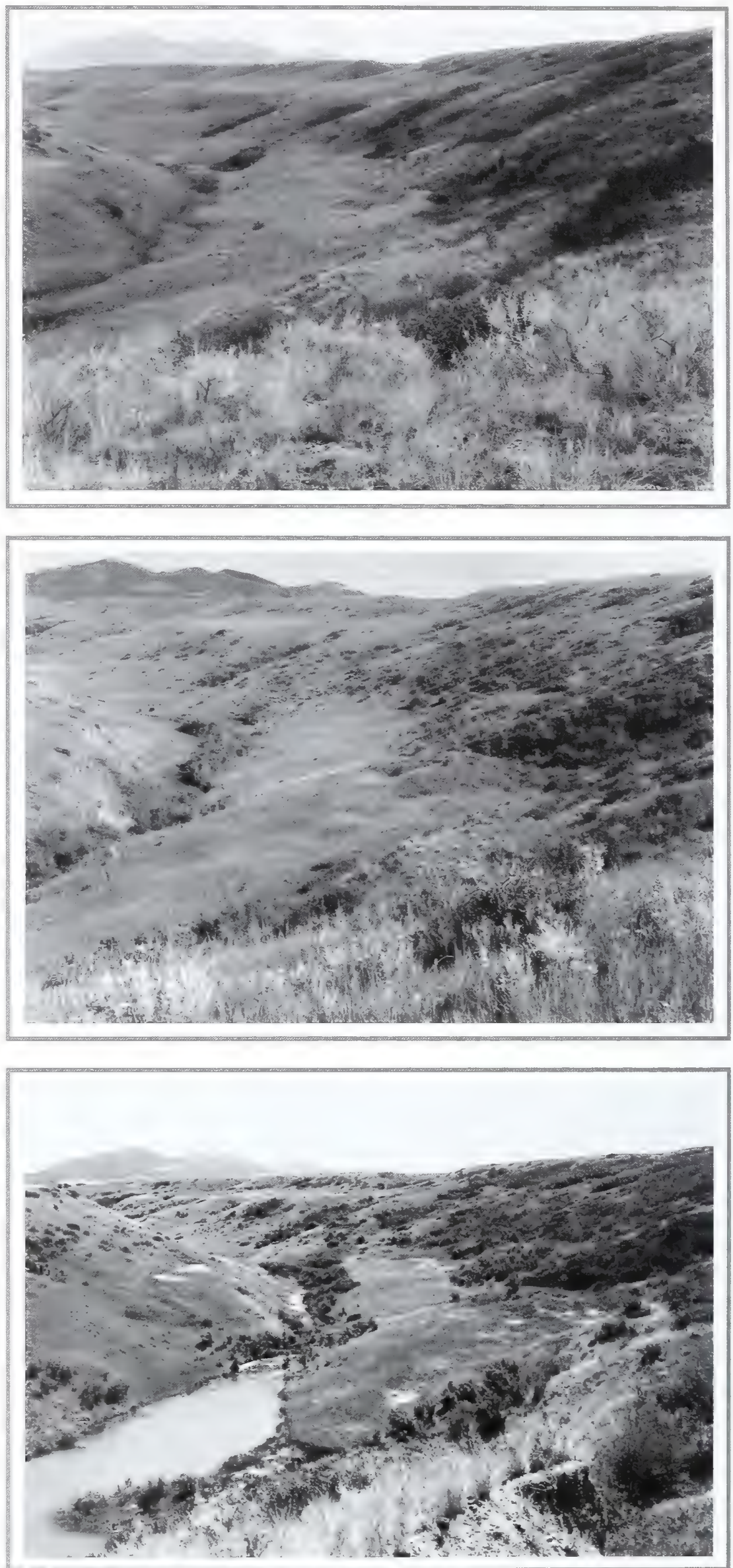


\section{Danvers, Montana}

\section{Location}

Fergus Co., MT; Sec. 2, R. 16 E., T. 17 N.; GPS-UTM 5234986 N, 602283 E.

About 20 miles northwest of Lewistown.

From Lewistown, Montana, travel north on U.S. Highway 191 about 9 miles, to Montana Highway 81. Turn left (west) onto Highway 81 and continue about 12 miles. Near this point is a left turnoff leading south to Danvers and a right turnoff leading north onto a private two-track road. Turn right and travel about 1 mile. The photopoint is about 75 yards north-northeast of cornerpost overlooking Warm spring Creek and its drainages.

\section{Description}

August 11, 1999

\section{Upland Near Photopoint}

Grasses. Agropyron spicatum

Forbs. Achillea millefolium, Artemisia ludoviciana

Shrubs and Trees. Artemisia frigida, Rhus trilobata, Artemisia cana

\section{Side Slopes}

Shrubs and Trees.

Shepherdia argentea, Prunus virginiana, Amelanchier alnifolia, Juniperus scopulorum

\section{Bottomland Along Drainage and Around Reservoir}

Grasses. Agropyron smithii, Koeleria pyramidata, Stipa viridula, Poa pratensis, Agropyron trachycaulum, Spartina pectinata

Forbs. Achillea millefolium, Artemisia ludoviciana

\section{Shrubs and Trees.}

Shepherdia argentea, Symphoricarpos albus, Prunus virginiana, Amelanchier alnifolia, Juniperus scopulorum

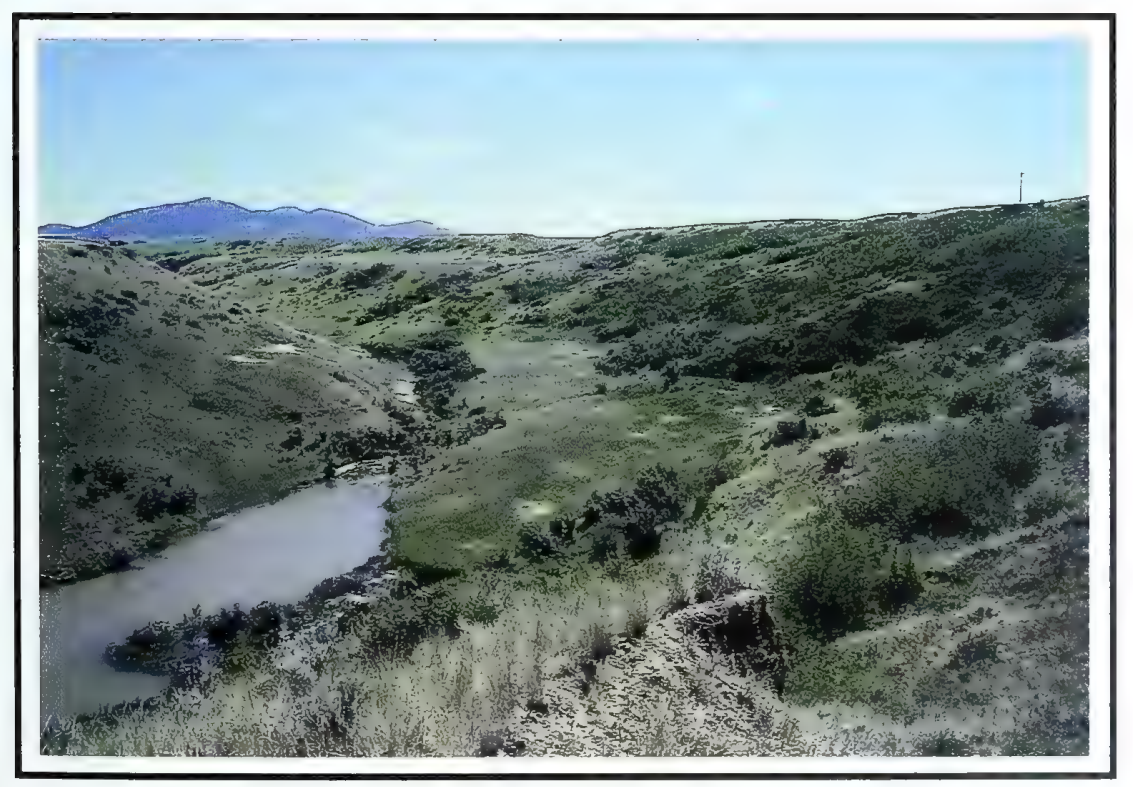

\section{Synopsis}

The 1998 photopoint is slightly below and south of the original photopoint. This change was necessary because the original point moved in conjunction with a large soil slump arising from the irrigation of cropland on the adjacent upland bench. The original "side creek bottom" is Warm Spring Creek, not the Judith River mentioned by Phillips in 1959. Shizachyrium scoparium has continued to decline along the upland, whereas a more mesic vegetation complex, dominated by Spartina pectinata, has developed in the bottomlands in conjunction with the construction of a small reservoir after 1959. Artemisia cana has also declined in abundance in foreground uplands, whereas Juniperus scopulorum, Amalanchier alnifolia, and Prunus virginiana has increased dramatically along the northfacing hillside (right side of photo). Pinus ponderosa has continued to increase in abundance on the distant mountain. 


\section{Original Photograph}

September 18, 1917.

Shantz O-12-1917.

Facing north.

\section{First Retake and Description}

June 30, 1959.

W.S.P., H-6-1959.

The original vegetation was Bouteloua spp. and Koeleria cristata. Carex filifolia is abundant in flat areas. Shrub in grass is Artemisia frigida. Shepherdia canadensis is a common shrub on the hillsides and bottomlands. The river has meandered and changed its course several times since the original picture. Pinus ponderosa on the mountains is much thicker (from Phillips 1963, p. 27).

\section{Second Retake}

July 21, 1998.

Kay-4329-1.
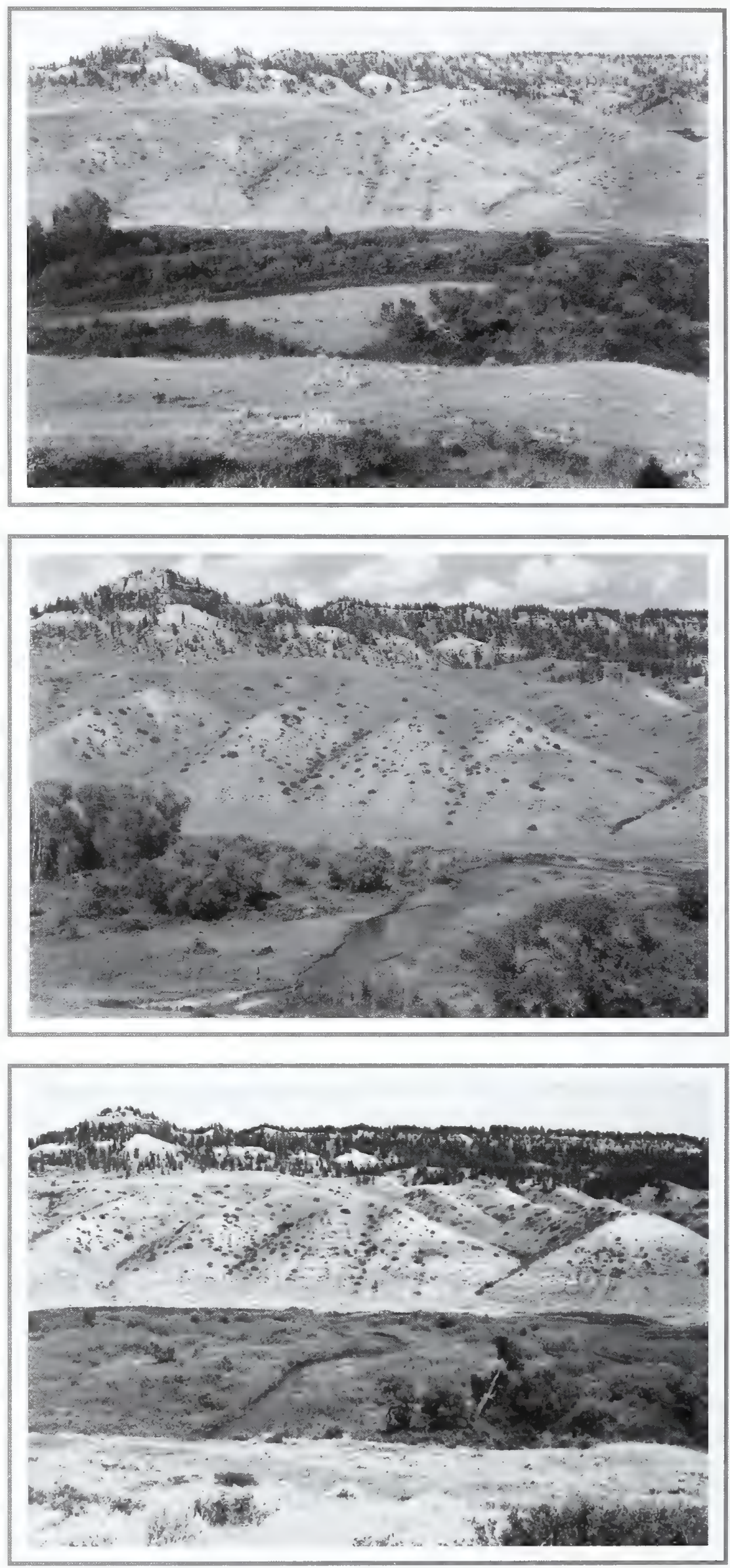


\section{Danvers, Montana}

\section{Location}

Fergus Co., MT; Sec. 2, R. 16 E., T. 17 N.; GPS-UTM 5235250 N, 602846 E.

About 20 miles northwest of Lewistown.

From Lewistown, Montana, travel north on U.S. Highway 191 about 9 miles, to Montana Highway 81. Turn left (west) onto Highway 81 and continue about 12 miles. Near this point is a left turnoff leading south to Danvers, Montana, and a right turnoff leading north onto a private two-track road. Turn right and travel about 1 mile. The photopoint is on the north aspect of the slope and north of the wheat pasture shown in the first set of photos (Danvers, Montana, page 4). Photopoint overlooks Warm Spring Creek.

\section{Description}

August 11, 1999

\section{Upland Including Ridgetops and Slopes}

Grasses. Bouteloua gracilis, Koeleria pyramidata, Agropyron smithii, Stipa comata

Forbs. Achillea millefolium, Artemisia ludoviciana

Shrubs. Rhus trilobata, Artemisia frigida, Artemisia cana

\section{Bottomland}

Grasses. Agropyron smithii, Koeleria pyramidata, Stipa viridula, Poa pratensis, Agropyron trachycaulum, Spartina pectinata

\section{Shrubs and Trees.}

Shepherdia argenteus, Symphoricarpos occidentalis, Prunus virginiana, Amelanchier alnifolia, Populus deltoides, Populus trichocarpa, Populus angustifolia, Salix exigua

\section{Synopsis}

Bottomland is Warm Spring Creek. Rather dramatic increase in abundance of Salix spp. has occurred since 1917, whereas abundance of Populus spp. has declined. Abundance of Pinus ponderosa on mountains and buttes has also increased tremendously since 1917, as that of Shepherdia argentea (originally reported as $S$. canadensis) on hillsides and bottomland. Creek has changed courses several times; note its direction is different in each photo. The 1959 photo shows a wide and somewhat less meandering stream compared with the earlier and later photos.

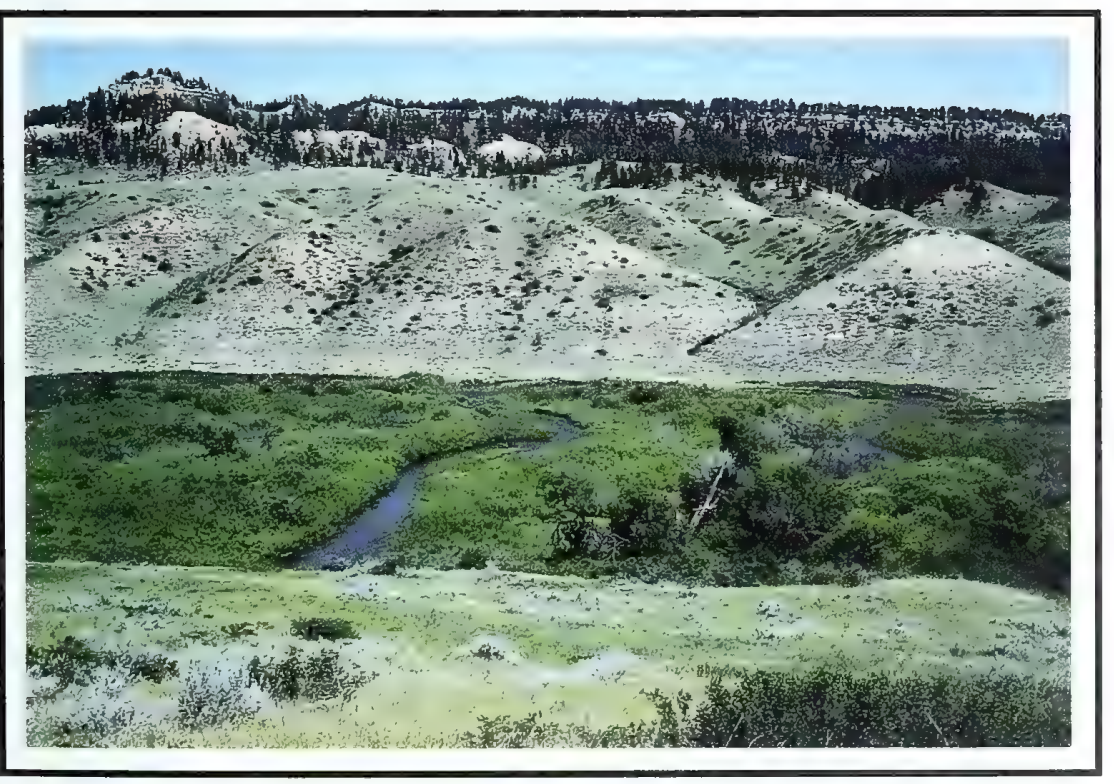




\section{Original Photograph}

September 23, 1917.

Shantz R-8-1917.

Facing northwest.

\section{First Retake and Description}

June 29, 1959. W.S.P., G-5-1959.

This picture illustrates a remarkable regrowth of the Pinus ponderosa. The vegetation in the foreground has little changed (from Phillips 1963, p. 35).

Second Retake

July 23, 1998.

Kay-4331-12A.
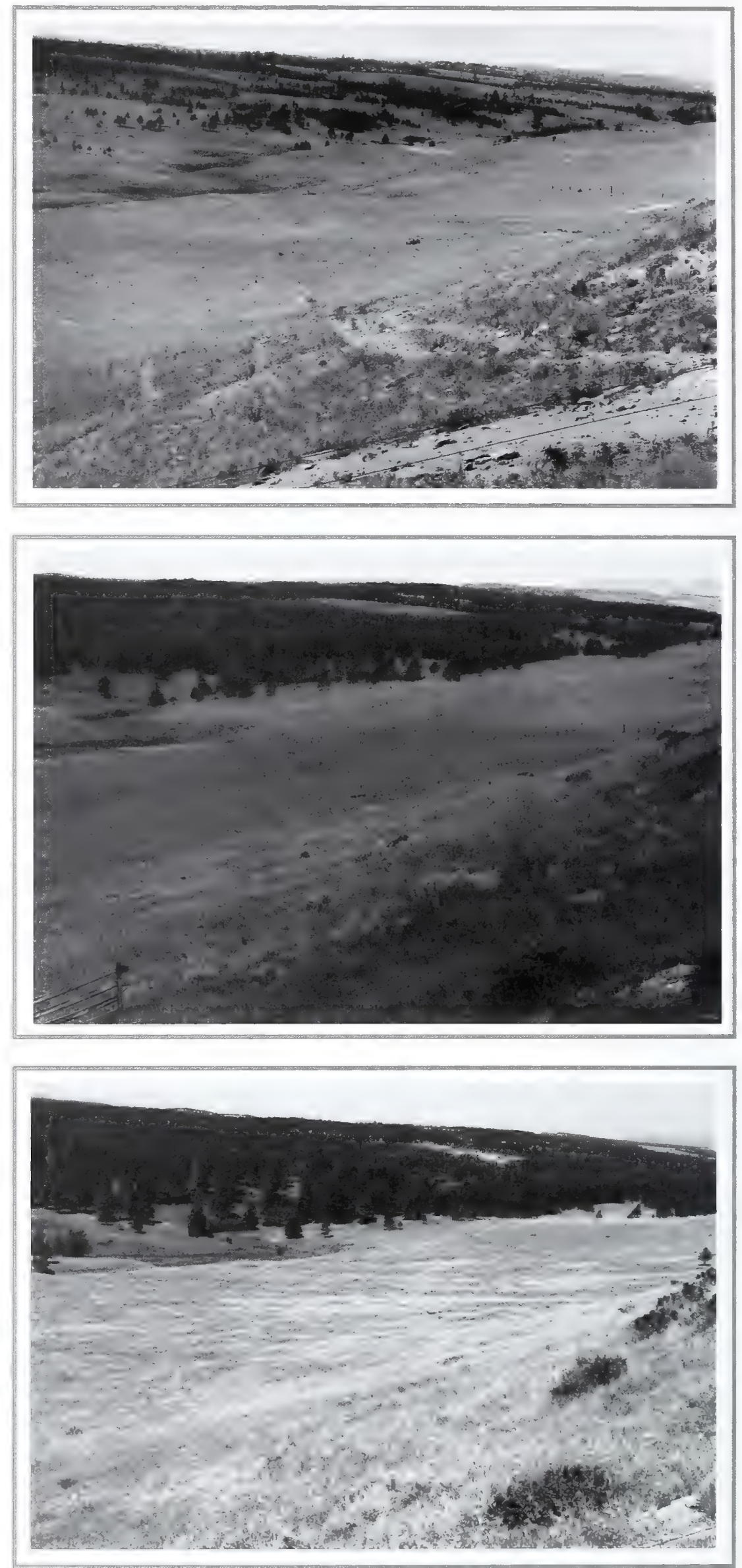


\section{Grassrange, Montana}

\section{Location}

Fergus Co., MT; Sec. 20, R. 23 E., T. 14 N.; GPS-UTM 5203446 N, 665626 E.

About 4 miles south of Grassrange.

From Grassrange, travel to the southwest corner of town. Take the left fork onto Tyler Cutoff Road, which crosses the south fork of McDonald Creek. Continue south after crossing the creek, about 4 miles. Photopoint is located west of the road before the road descends a steep grade.

\section{Description}

August 11, 1999

\section{Side Slope Along Fence}

Grasses. Agropyron

spicatum, Agropyron

cristatum, Poa pratensis

Forbs. Achillea millefolium, Melilotus officinalis

Shrubs. Rosa woodsii

\section{Upland Behind Fence}

Grasses. Agropyron smithii, Stipa comata, Koeleria pyramidata, Bouteloua gracilis, Agropyron cristatum

Forbs. Psoralea tenuiflora, Melilotus officinalis, Solidago spp.

Shrubs. Artemisia cana, Artemisia frigida, Rhus trilobata

\section{Synopsis}

Original photo served as the cover shot for Phillips" (1963) publication. In contrast to 1917 , barren areas are completely vegetated in 1998, with Melilotus officinale invading open areas, particularly near the road and along the fence line. The most apparent change is the dramatic increase of Pinus ponderosa on the hillside in the background. Originally considered a moderate cover of Pinus ponderosa, this site now supports a closed canopy. The central drainage area is the south fork of McDonald Creek. No notable change in drainage vegetation has occurred since 1917.

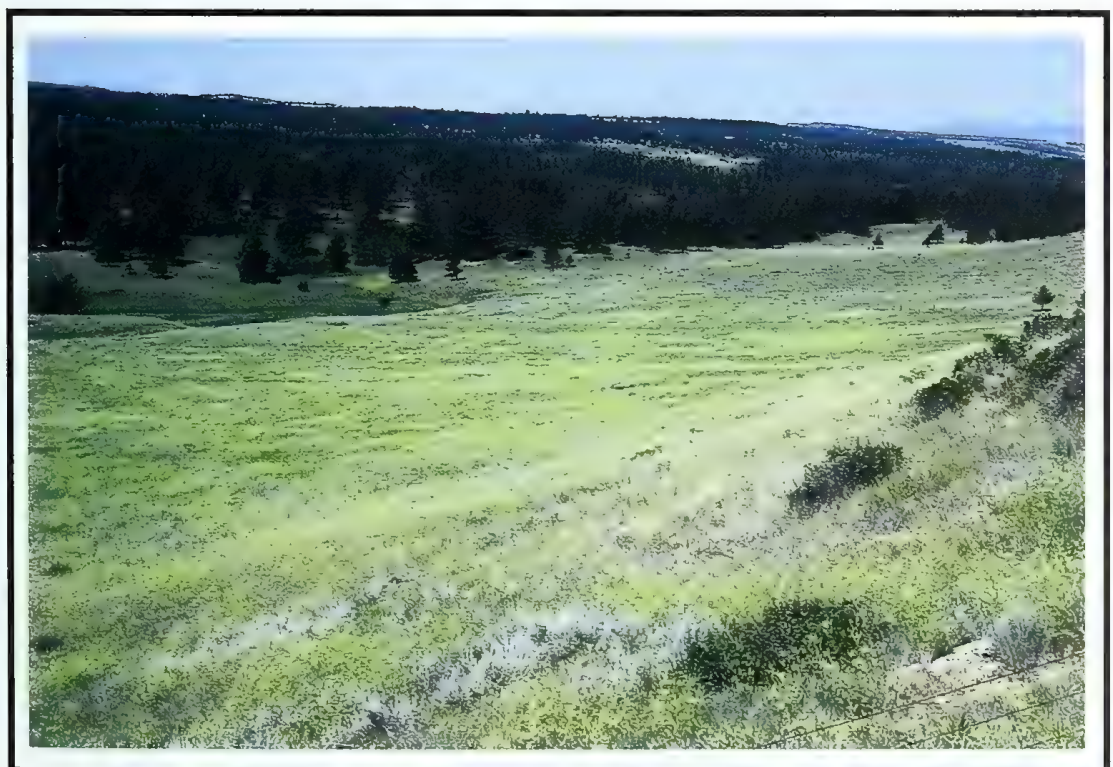




\section{Original Photograph}

September 23, 1917.

Shantz R-9-1917.

Facing north.

\section{First Retake and Description}

June 29, 1959. W.S.P., G-6-1959.

Clumps of Juniperus growing on the side of a wash cut in the original picture. Dr. Shantz mentions both Juniperus horizontalis and Juniperus communis. In the retake there was only one plant of Juniperus communis left. The shrub in the foreground is mainly Shepherdia canadensis (from Phillips 1963, p. 37).
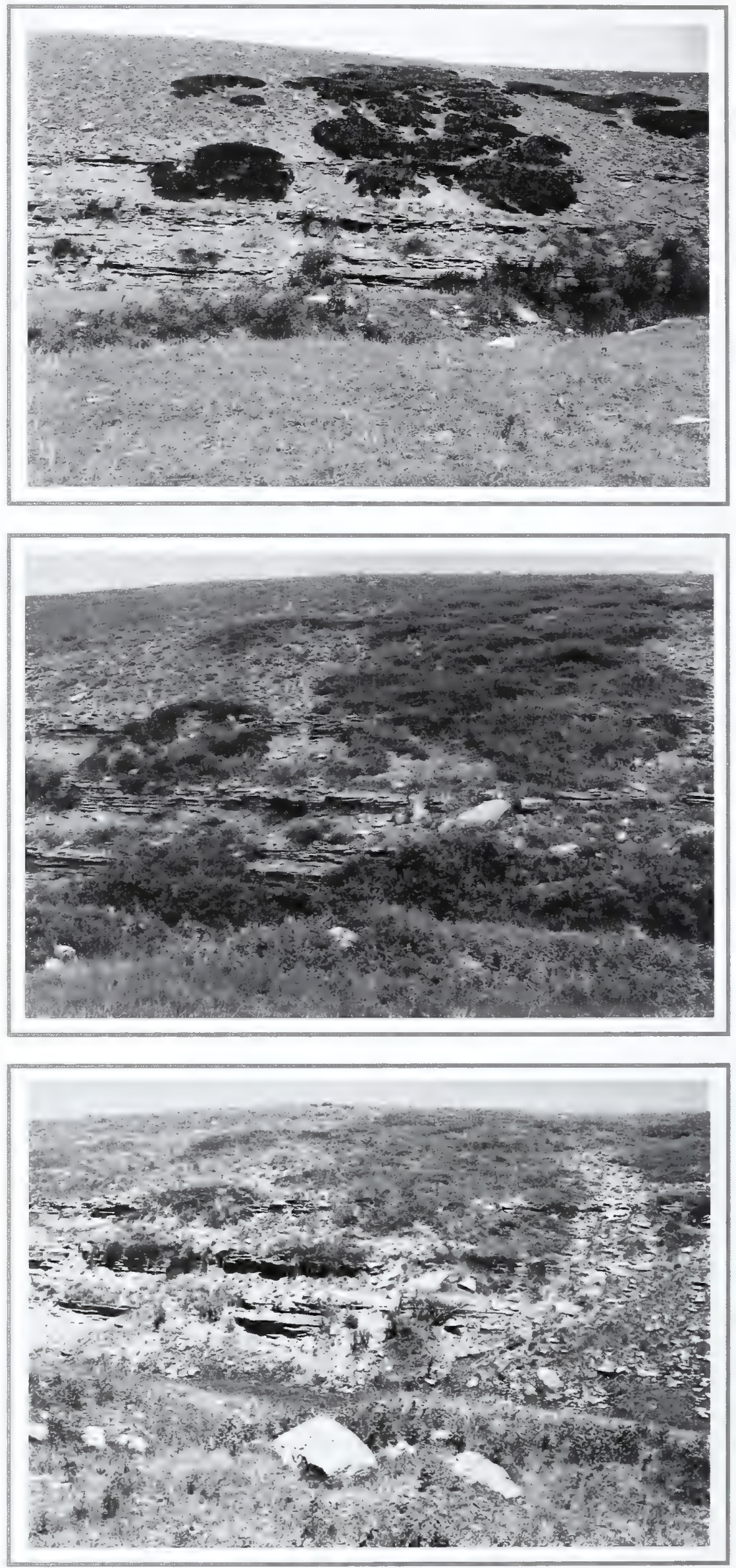


\section{Grassrange, Montana}

\section{Location}

Fergus Co., MT; Sec. 7, R. 22 E., T. 13 N.; GPS-UTM 5196943 N, 662854 E.

About 9 miles southwest of Grassrange.

From Grassrange, travel to the southwest corner of town. Take the left fork onto Tyler Cutoff Road, which crosses the south fork of McDonald Creek. Continue south and west after crossing the creek, about 9 miles. Photopoint is about 75 yards west of road near a livestock watering tank.

\section{Description}

August 11, 1999

\section{Upland Near Photopoint}

Grasses. Agropyron smithii, Agropyron cristatum, Poa pratensis

\section{Hillside}

Grasses. Agropyron smithii, Koeleria pyramidata, Stipa comata, Bouteloua gracilis

Shrubs. Juniperus horizontalis, Rhus trilobata, Shepherdia canadensis, Symphoricarpos occidentalis

\section{Synopsis}

This site is of a hillside with very thin soil and a rock outcrop, which is in center of the photo. The diversity and density of shrub species had increased on this site by the time the 1959 photo was taken. The 1998 photo shows an increased use similar to that in 1917. A livestock watering tank, located about 50 yards behind the photopoint, may be affecting this area.

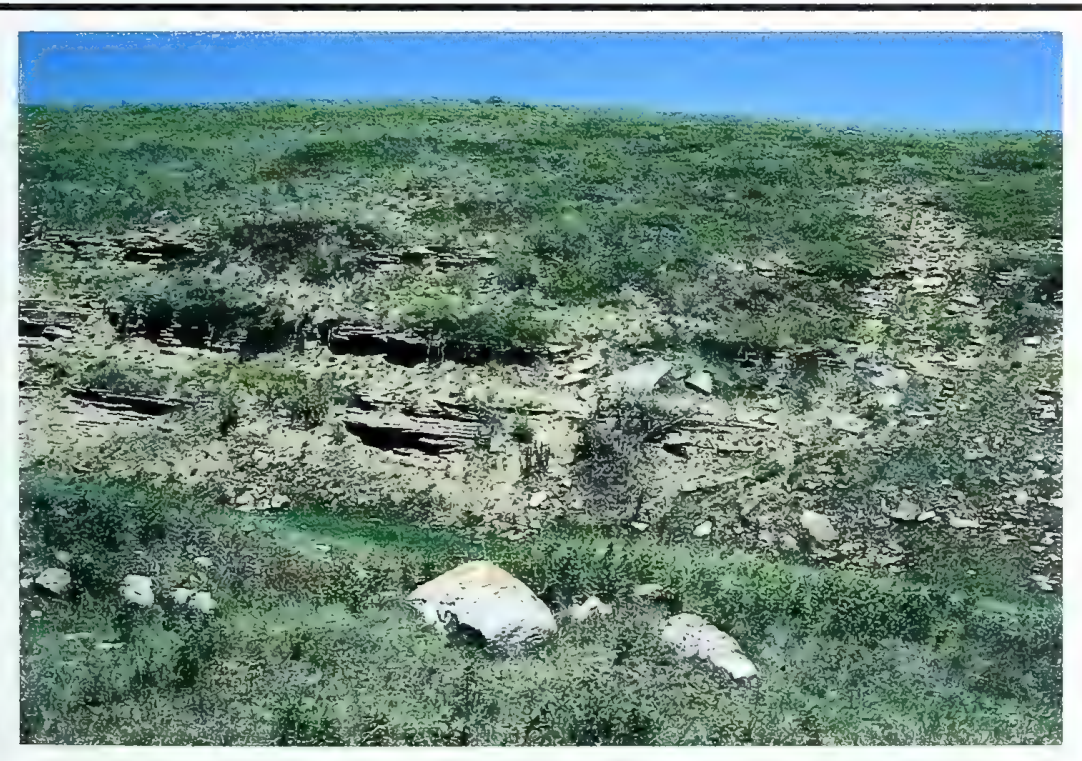




\section{Original Photograph}

September 16, 1917.

Shantz N-10-1917.

Facing northwest.

\section{First Retake and Description}

August 6, 1960. W.S.P., B-5-1960.

The original grass cover consisted of Bouteloua gracilis, Koeleria cristata, and Agropyron smithii, with pines on the hills. In the retake, the same plants are still present, but $K$. cristata seems to be dominant (from Phillips 1963, p. 43).
Second Retake

July 23, 1998. Kay-4326-8.
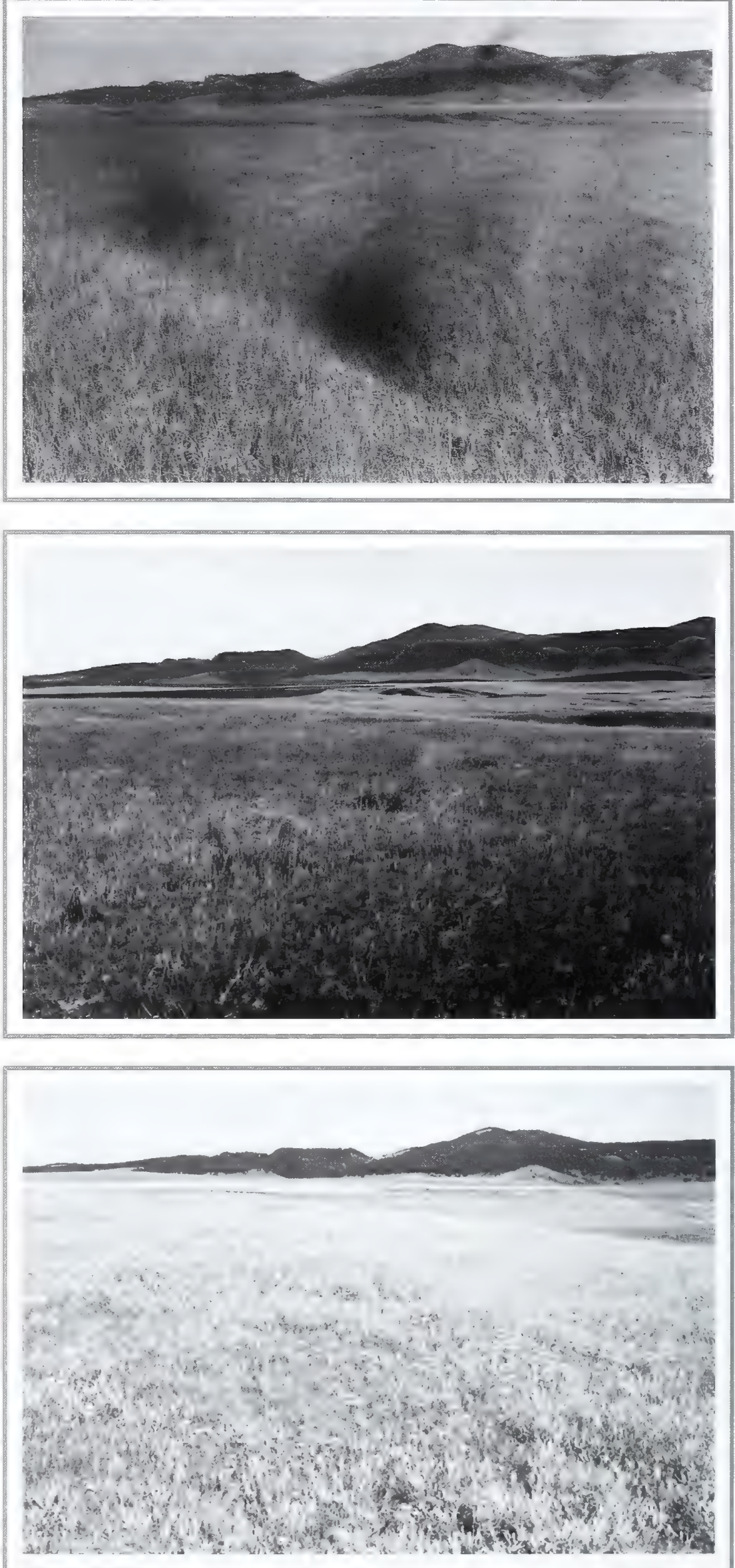


\section{Lewistown, Montana}

\section{Location}

Fergus Co., MT; Sec. 21, R. 18 E., T. 16 N.; GPS-UTM 5221028 N, 617215 E.

About 5 miles north-northwest of Lewistown.

From Lewistown, travel north on U.S. Highway 191 about 4.5 miles. Turn left (west) onto graveled road (Danvers / Denton Cutoff Road). Continue west, then north, for about 0.7 mile. Photopoint is west of road before crossing a drainage.

\section{Description}

August 10, 1999

\section{Upland Near Photopoint}

Grasses. Agropyron smithii, Koeleria pyramidata, Bouteloua gracilis, Poa pratensis, Stipa comata, Stipa columbiana

Forbs. Achillea millefolium, Liatris punctata, Psoralea tenuiflora, Phlox hoodii, Melilotus officinalis
Shrubs. Artemisia frigida, Gutierrezia sarothrae

\section{Bottomland Near Right Center of Photo}

Grasses. Phleum pratense, Poa pratensis

Forbs. Rumex spp., Melilotus officinalis

\section{Synopsis}

Left center of photo shows a gradual increase in the cultivated area since 1917. Upland vegetation to cultivated area was invaded by Melilotus officinalis sometime after 1960. A small reservoir located in the depression between the uplands in the foreground and background is altering area drainage patterns while supporting large amounts of Rumex spp. Cover and density of Pinus ponderosa have continued to increase on South Mocassin Mountains.

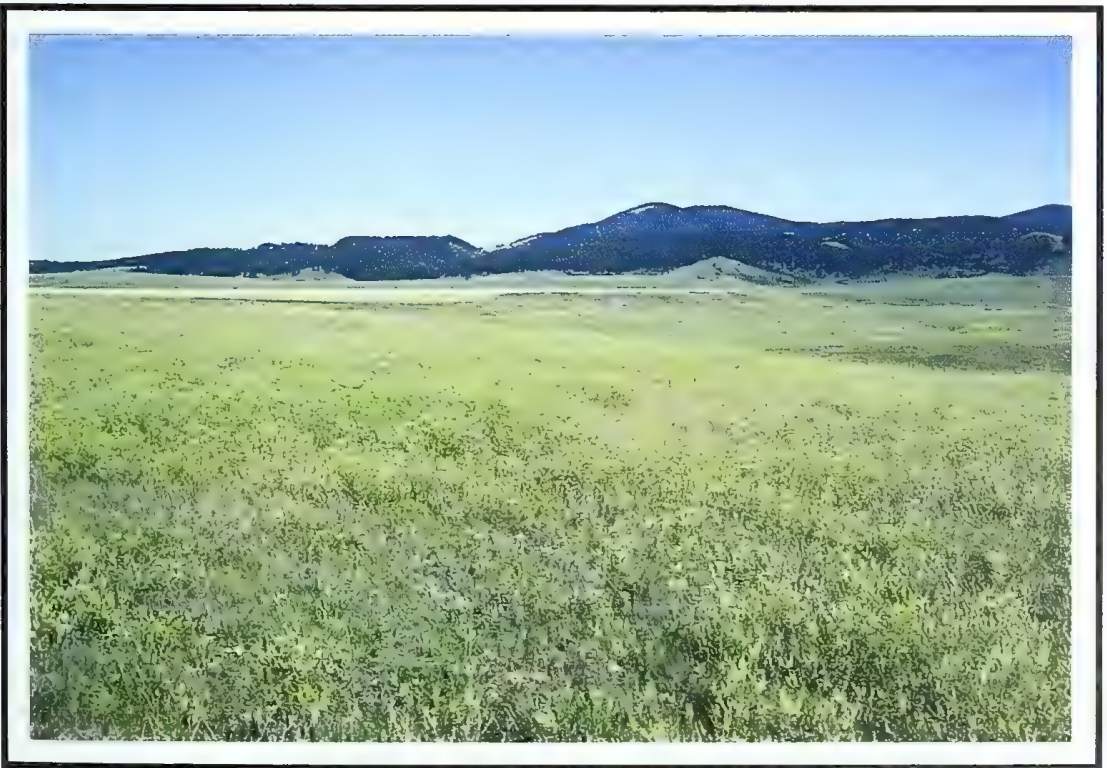




\section{Original Photograph}

September 23, 1917. Reproduced black and white slide; Shantz R-31917 missing.

Facing west.

\section{First Retake and Description}

June 30, 1959. W.S.P., No. 2119.

Stipa and Bouteloua spp. are the main grasses in both pictures. Pinus ponderosa on the Judith Mountains has increased noticeably. Note the same fence post by the hood of the cars, although the new road has been moved back 100 yards (from Phillips 1963, p. 45).

\section{Second Retake}

July 22, 1998.

Kay-4329-24.
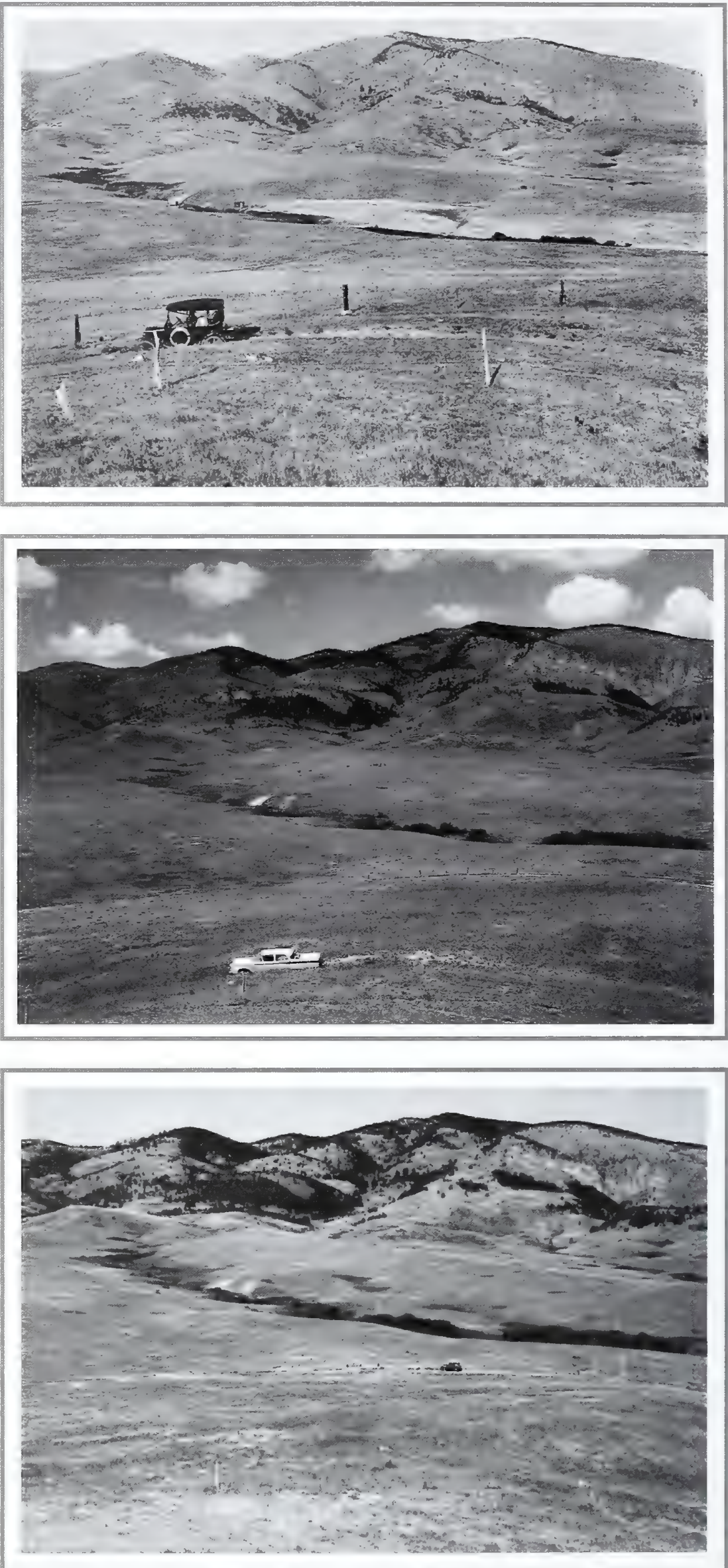


\section{Lewistown, Montana}

\section{Location}

Fergus Co., MT; Sec. 13, R. 21 E., T. 17 N.; GPS-UTM 5233646 N, 651673 E.

About 10 miles south-southwest of Roy.

From Roy, Montana, travel south through town on Black Butte Road, which runs between Roy and Giltedge. Travel south about 10 miles. Photopoint is to the east, about 100 yards above present road and near abandoned road.

\section{Description}

August 10, 1999

\section{Upland to Road}

Grasses. Agropyron smithii, Stipa comata, Bromus japonicus, Bromus inermis, Poa pratensis, Stipa viridula

Forbs. Artemisia ludoviciana, Chrysopsis villosa, Achillea millefolium, Melilotus officinale

Shrubs. Artemisia cana, Chrysothamnus viscidiflorus, Gutierrezia sarothrae, Artemisia frigida

\section{Upland Between Road and Drainage}

Grasses. Agropyron smithii, Poa pratensis

Forbs. Artemisia ludoviciana, Melilotus officinalis

\section{Drainage}

Shrubs and Trees.

Symphoricarpos occidentalis, Prunus virginiana, Crataegus succulenta

\section{Synopsis}

Density and cover of Pinus ponderosa growing on Judith Mountains in background have increased dramatically over time. So have the density and cover of riparian shrubs, particularly Symphoricarpos occidentalis, Prunus virginiana, and Crataegus succulenta. Although the upland herbaceous vegetation in the foreground is species rich, upland vegetation in the background is largely dominated by Agropyron smithii and Poa pratensis.

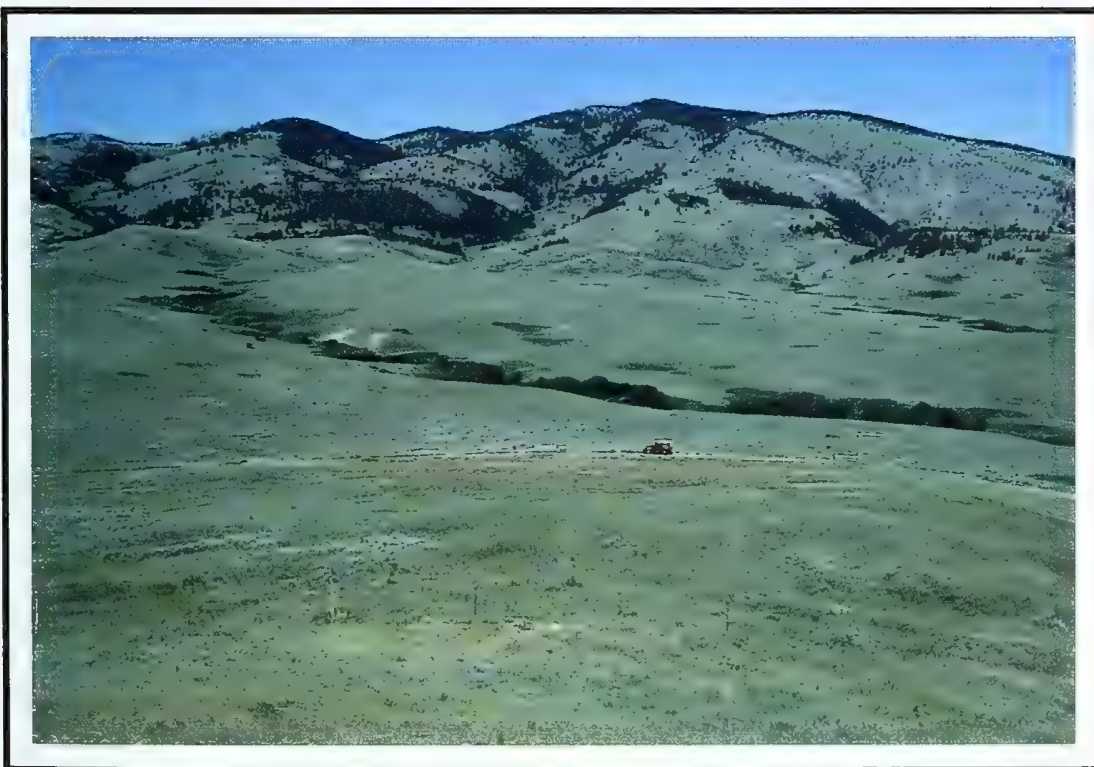




\section{Original Photograph}

September 23, 1917.

Shantz R-5-1917.

Facing northeast.

\section{First Retake and Description}

June 29, 1959. W.S.P., G-10-1959.

The grass in this area has shown remarkable recovery, although there is a lot of Selaginella densa in it. Opuntia spp. is very common in this grassland, although Shantz does not mention it in the original publication (from Phillips 1963, p. 47).
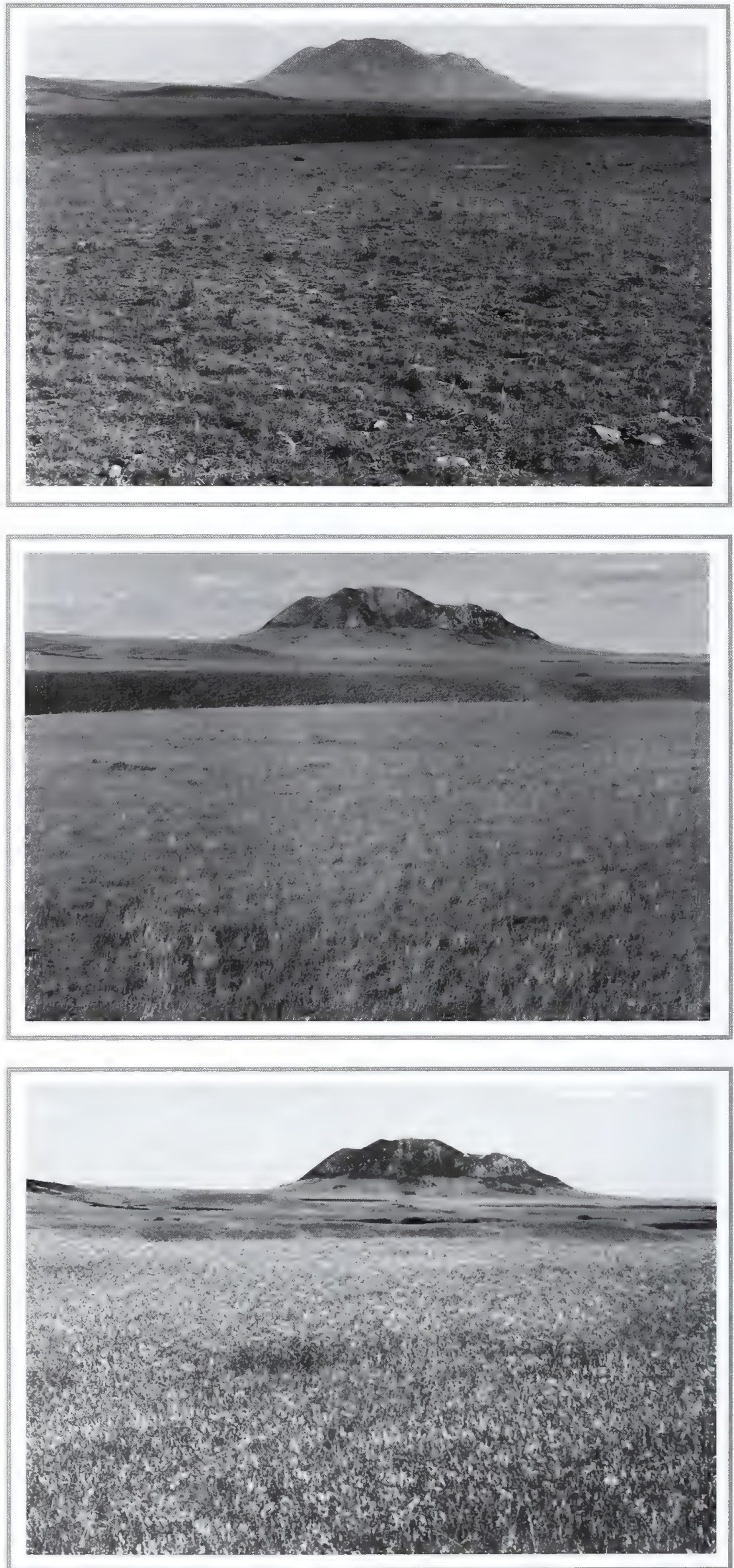


\section{Lewistown, Montana}

\section{Location}

Fergus Co., MT; Sec. 4, R. 21 E., T. 16 N.; GPS-UTM 5226185 N, 646907 E.

About 16 miles southwest of Roy.

From Roy, Montana, travel south through town on Black Butte Road, which runs between Roy and Giltedge. Continue about 16 miles south and west. Photopoint is located north of the road, about 50 yards.

\section{Description}

August 10, 1999

\section{Upland}

Grasses. Agropyron smithii, Koeleria pyramidata, Stipa comata, Poa pratensis

Forbs. Liatris punctata, Achillea millefolium, Chrysopsis villosa
Shrubs. Rosa woodsii, Artemisia frigida

\section{Drainage}

Trees. Populus spp.

\section{Synopsis}

An abundance of Melilotus officinalis is evident in the 1998 photo but not in earlier photos. However, only very small seedlings were present during the 1999 site visit. This reduction was attributed to mechanical or herbicide treatment or both. The amount of Pinus ponderosa on Black Butte has increased considerably over time. Although the presence of Opuntia spp. is noted in 1959, it was not present in 1998 or 1999.

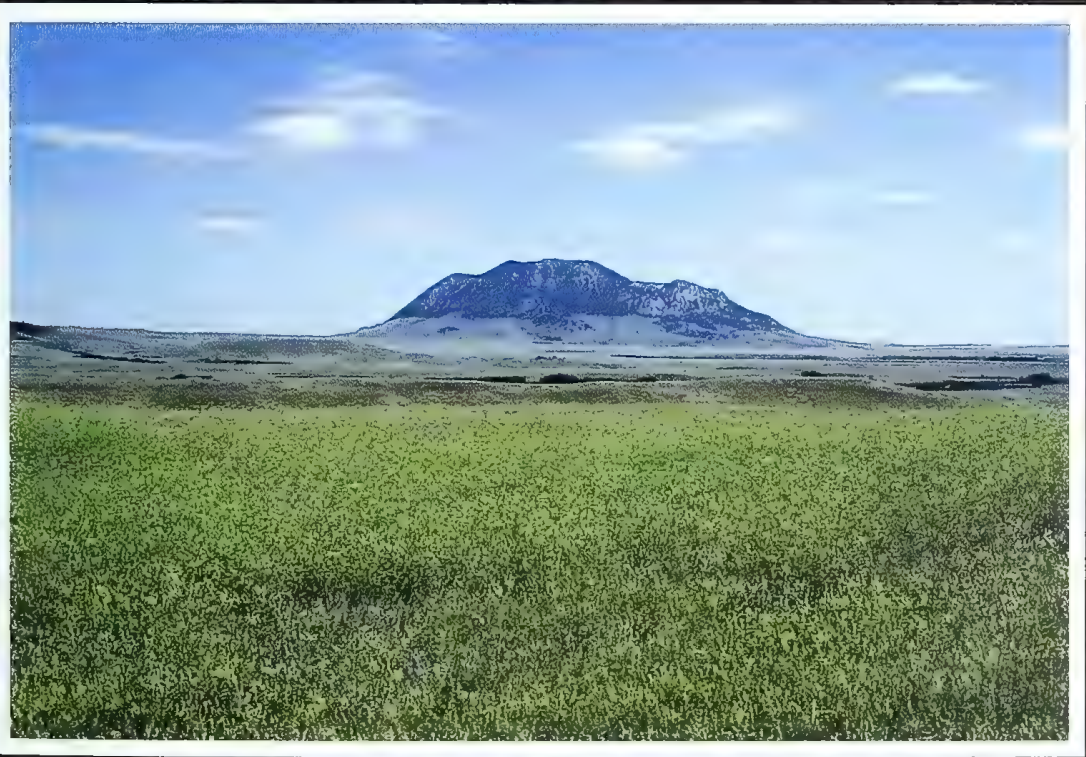




\section{Original Photograph}

September 23, 1917.

Shantz R-4-1917.

Facing north.

\section{First Retake and Description}

June 29, 1959. W.S.P., G-11-1959.

No description available.

Second Retake

July 22, 1998.

Kay-4329-18.
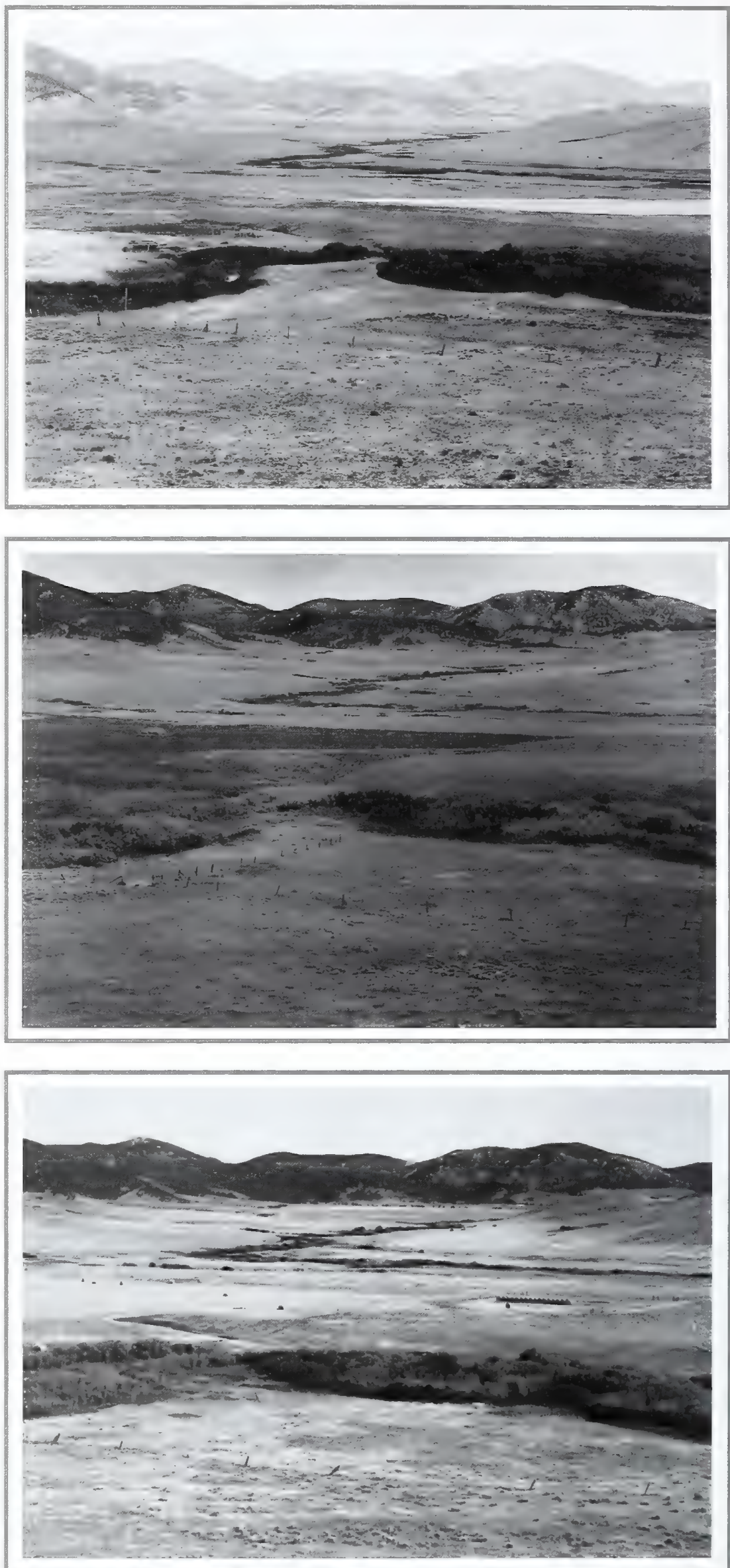


\section{Lewistown, Montana}

\section{Location}

Fergus Co., MT; Sec. 13, R. 20 E., T. 16 N.; GPS-UTM 5223136 N, 641749 E.

About 21.5 miles southwest of Roy.

From Roy, Montana, travel south through town on Black Butte Road, which runs between Roy and Giltedge. Continue about 21.5 miles south and west. Photopoint is located directly north of road and on hill parallel to road.

\section{Description}

August 10, 1999

\section{Upland}

Grasses. Agropyron smithii, Bouteloua gracilis, Agropyron spicatum, Stipa comata, Agropyron cristatum

Forbs. Achillea millefolium, Liatris punctata, Artemisia ludoviciana, Solidago spp.

Shrubs. Artemisia tridentata, Artemisia frigida, Gutierrezia sarothrae

\section{Bottomland}

Grasses. Agropyron smithii, Bouteloua gracilis, Stipa comata

Forbs. Achillea millefolium, Liatris punctata, Artemisia ludoviciana, Solidago spp.

Shrubs. Artemisia cana, Artemisia frigida, Symphoricarpos albus

\section{Drainage}

Shrubs. Salix exigua, Crataegus succulenta, Prunus virginiana, Shepherdia argentea

\section{Synopsis}

Since the 1959 photo, the bottomland has been cultivated and planted to Medicago sativa (alfalfa) and Hordeum vulgare (barley). The density and cover of Pinus ponderosa on Judith Mountains in the background has continued to increase over time. Similarly, the density and size of streambank shrubs have continued to increase, although species diversity has remained relatively stable.

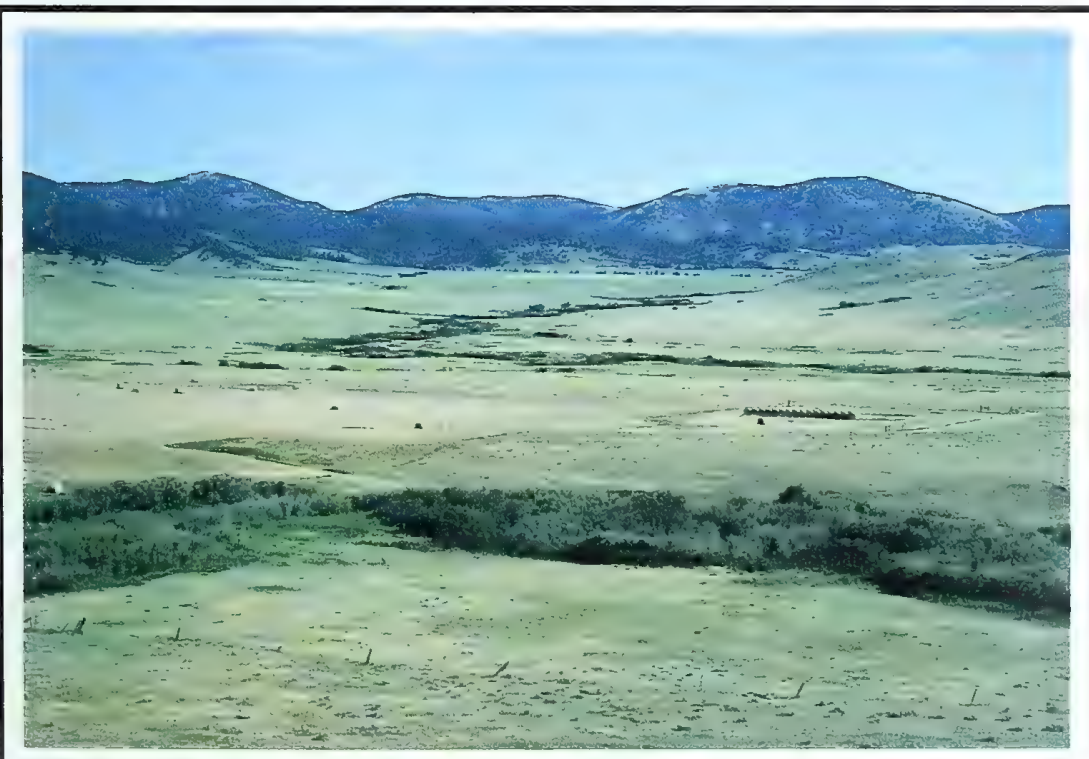




\section{Original Photograph}

August 10, 1918.

Shantz U-6-1918.

Facing west.

\section{First Retake and Description}

August 8, 1960. W.S.P., D-2-1960.

Yellow pines in the two pictures show little change, except the increase in size. Number of trees about the same. Dr. Shantz marked this picture "Type of Divide." The grass is mainly Grama grass with occasional Andropogon scoparius and Calamovilfa longifolia.

\section{Second Retake}

July 24, 1998.

Kay-4331-23A.
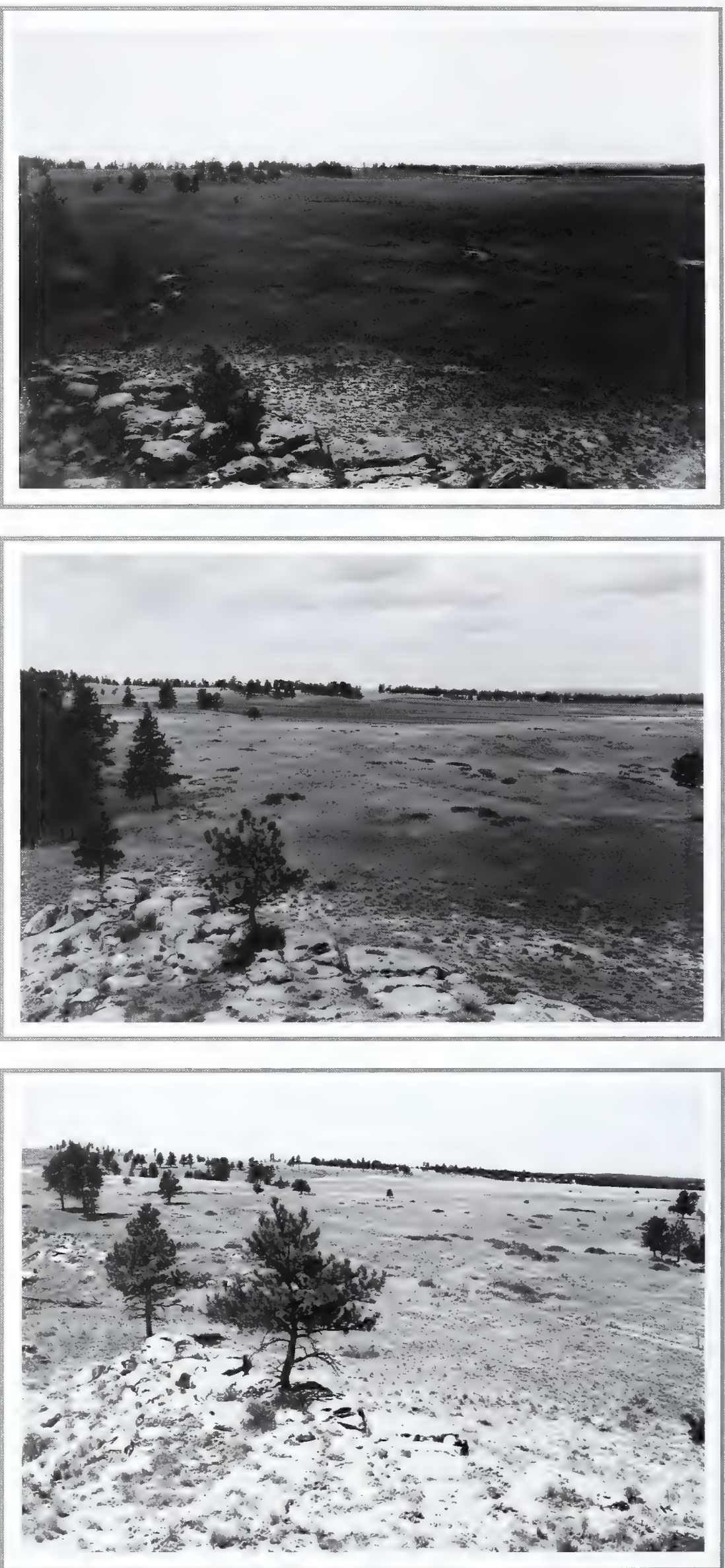


\section{Roundup, Montana}

\section{Location}

Musselshell Co., MT; Sec. 21, R. 26 E., T. 6 N.; GPS-UTM 5125394 N, 694957 E.

About 14 miles south of Roundup.

From Roundup, travel south about 14 miles on U.S. Highway 87. One-hundred yards south of mile marker 34, turn right (west) on Majerus Road (gravel road). Follow road 0.6 mile, then turn left (east) onto tertiary, unimproved trail. Continue about 0.2 mile. Photopoint is on top of high rock ledge located about 100 yards south of the tertiary road.

\section{Description}

August 12, 1999

\section{Rock Ledge}

Grasses. Agropyron spicatum

Forbs. Erigeron spp.

\section{Between Rock Ledge and Fence}

Grasses. Agropyron smithii, Agropyron spicatum, Bouteloua gracilis

Shrubs. Chrysothamnus nauseosus, Tetradymia canescens, Gutierrezia sarothrae

\section{Beyond Fence to Cropland}

Grasses. Agropyron smithii, Stipa comata, Bouteloua gracilis, Buchloe dactyloides, Koeleria pyramidata, Agropyron intermedium, Poa pratensis, Bromus japonicus

Shrubs and Trees. Rhus trilobata, Symphoricarpos occidentalis, Artemisia cana, Artemisia frigida, Pinus ponderosa

\section{Synopsis}

The major change is the increase in density and cover of Pinus ponderosa across the landscape. Growth of individual trees is apparent. Landscape on left side of picture shows remnants of a fire from 1984, which left some snags and removed several conifers. Cropland in center of photo has existed at least since 1918.

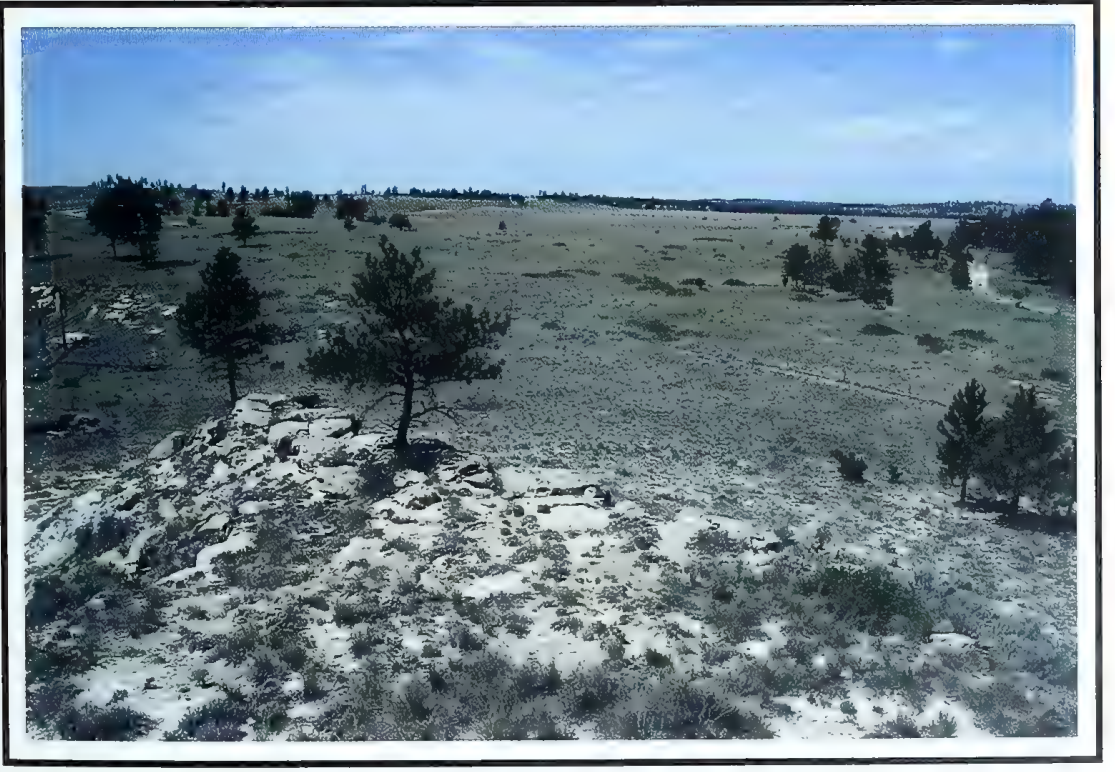




\section{Original Photograph}

August 10, 1918.

Shantz U-1 1-1918.

Facing east.

\section{First Retake and Description}

June 28, 1959. W.S.P.,

F-6-1959.

This is looking in the opposite direction from the other picture in this panorama (U6 , see page 22 ). It shows the development of the tree vegetation. A few more trees are evident. There were some cultivated areas in the middle background near the end of the road which have been abandoned and are now regrassed. The over-all picture shows the general development of the forest (from Phillips 1963, p. 55).

\section{Second Retake}

July 24, 1998.

Kay-4331-32A.
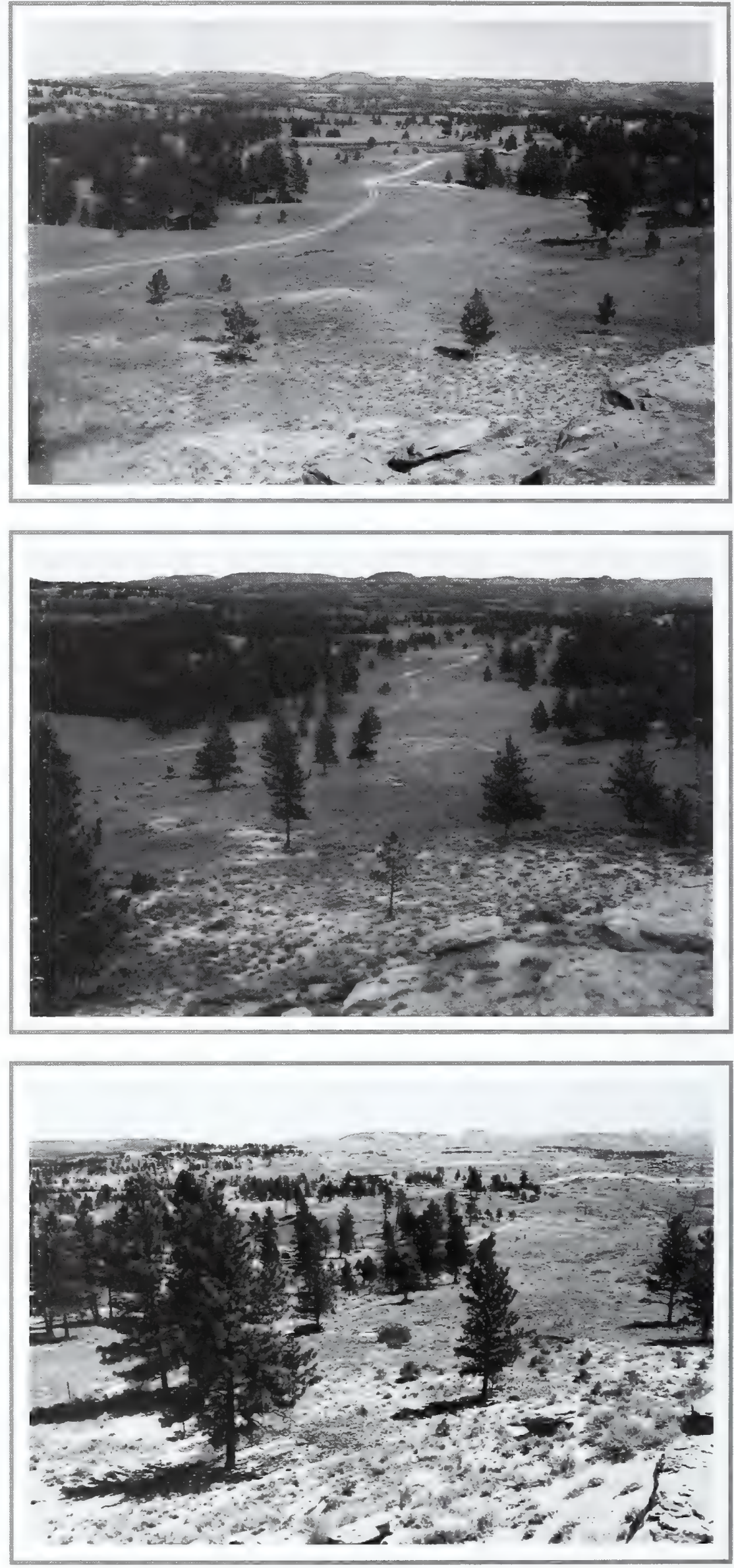


\section{Roundup, Montana}

\section{Location}

Musselshell Co., MT; Sec. 21, R. 26 E., T. 6 N.; GPS-UTM 5125394 N, 694957 E.

About 14 miles south of Roundup.

From Roundup, travel south about 14 miles on U.S. Highway 87. One hundred yards south of mile marker 34, turn right (west) on Majerus Road (gravel road). Follow road 0.6 mile, then turn left (east) onto tertiary, unimproved trail. Continue about 0.2 mile on tertiary road. Photopoint is on top of high rock ledge, located about 100 yards south of the tertiary road.

\section{Description}

August 12, 1999

\section{Rock Ledge}

Grasses. Agropyron spicatum

Forbs. Erigeron spp.

\section{Rock Ledge to Highway \\ (bottom right of photo)}

Grasses. Agropyron smithii, Stipa comata, Bouteloua gracilis, Bromus japonicus, Poa pratensis

\section{Shrubs and Trees.}

Chrysothamnus nauseosus, Artemisia cana, Gutierrezia sarothrae, Pinus ponderosa

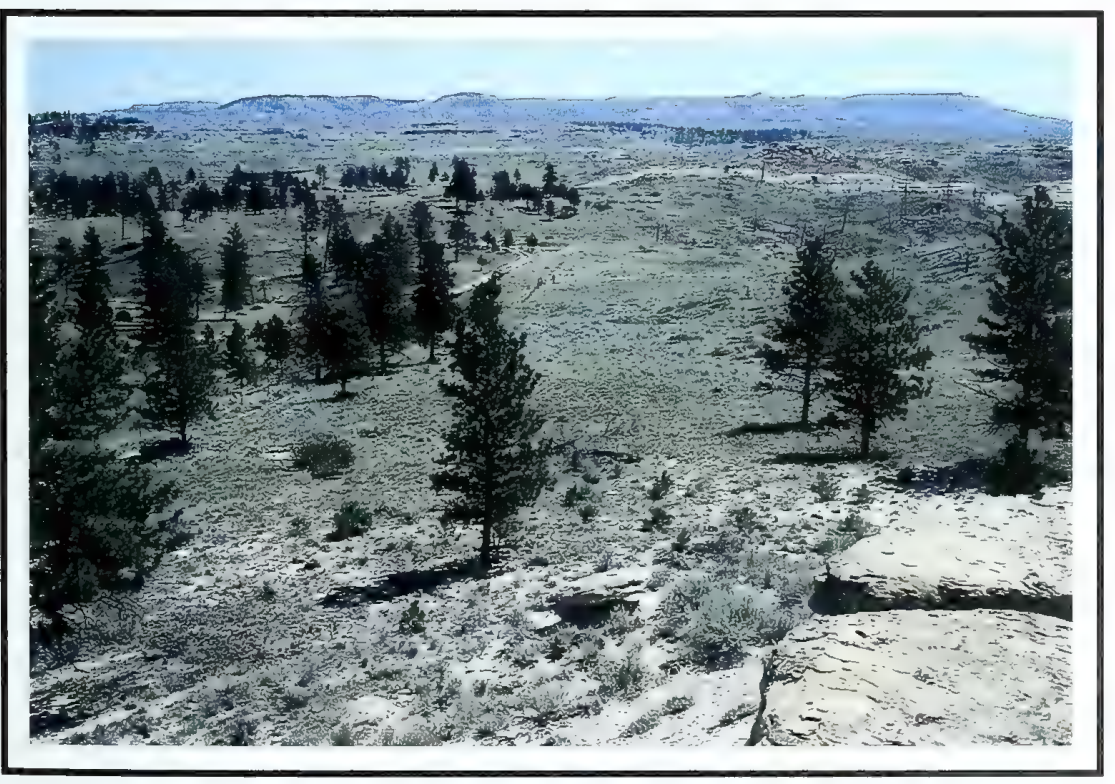

\section{Synopsis}

The greatest apparent vegetation change is in the size of the Pinus ponderosa trees throughout the area. Reduced $P$. ponderosa cover on the right-hand side of 1998 photo shows results of a 1984 fire. The apparent reduction in cover on the left-hand portion of the photo was not readily apparent during the 1998 and 1999 on-site visits; no explanation is offered other than the camera angle in 1998 was slightly different than those in 1918 and 1958 photos, or recent housing development projects are thinning out the trees (note houses in upper center portion of photo). Although descriptions of vegetation are missing from early in the century, current composition suggests gradual intrusion of Poa pratensis and Bromus japonicus, two invasive species. The road cut, near the center right of the 1998 photo, is parallel to U.S. Highway 87. 


\section{Original Photograph}

August 10, 1918. Shantz V-2-1918. Facing southwest.

\section{First Retake and Description}

June 28, 1959. W.S.P., No. 2365.

No description available.

\section{Second Retake}

July 24, 1998.

Kay-4333-7.
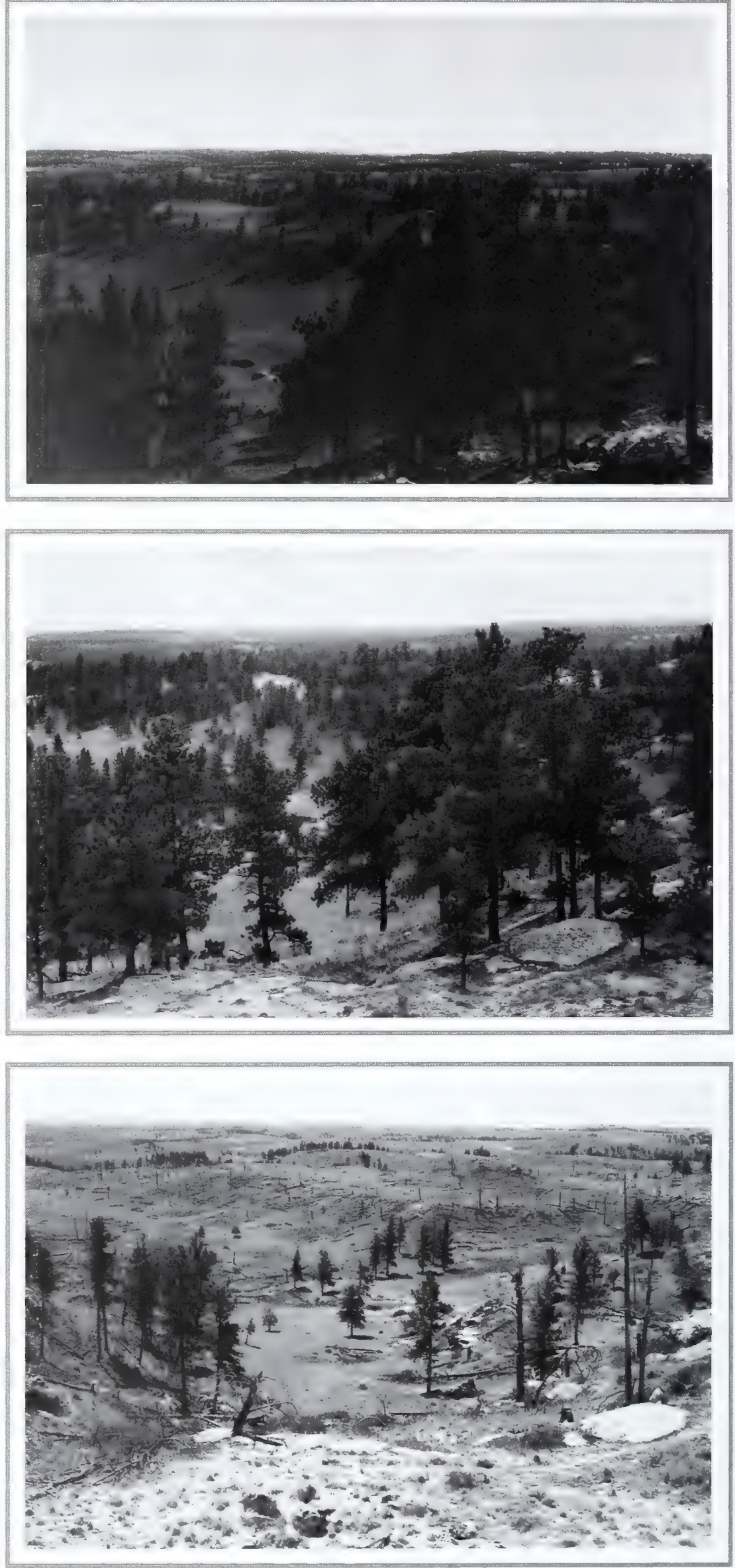


\section{Roundup, Montana}

\section{Location}

Musselshell Co., MT; Sec. 21, R. 26 E., T. 6 N.; GPS-UTM 5125394 N, 694957 E.

About 14 miles south of Roundup.

From Roundup, travel south about 14 miles on U.S. Highway 87. One hundred yards south of mile marker 34, turn right (west) on Majerus Road (gravel road). Follow road 0.6 mile, then turn left (east) onto tertiary, unimproved trail. Continue about 0.2 mile on tertiary road. Photopoint is on top of high rock ledge, located about 100 yards south of the tertiary road.

\section{Description}

August 12, 1999

\section{Rock Ledge}

Grasses. Agropyron spicatum

Forbs. Erigeron spp.

\section{Uplands and Ridges}

Grasses. Agropyron smithii, Stipa comata, Bouteloua gracilis, Bromus japonicus, Poa pratensis

\section{Shrubs and Trees.}

Chrysothamnus nauseosus, Rhus trilobata, Gutierrezia sarothrae, Pinus ponderosa

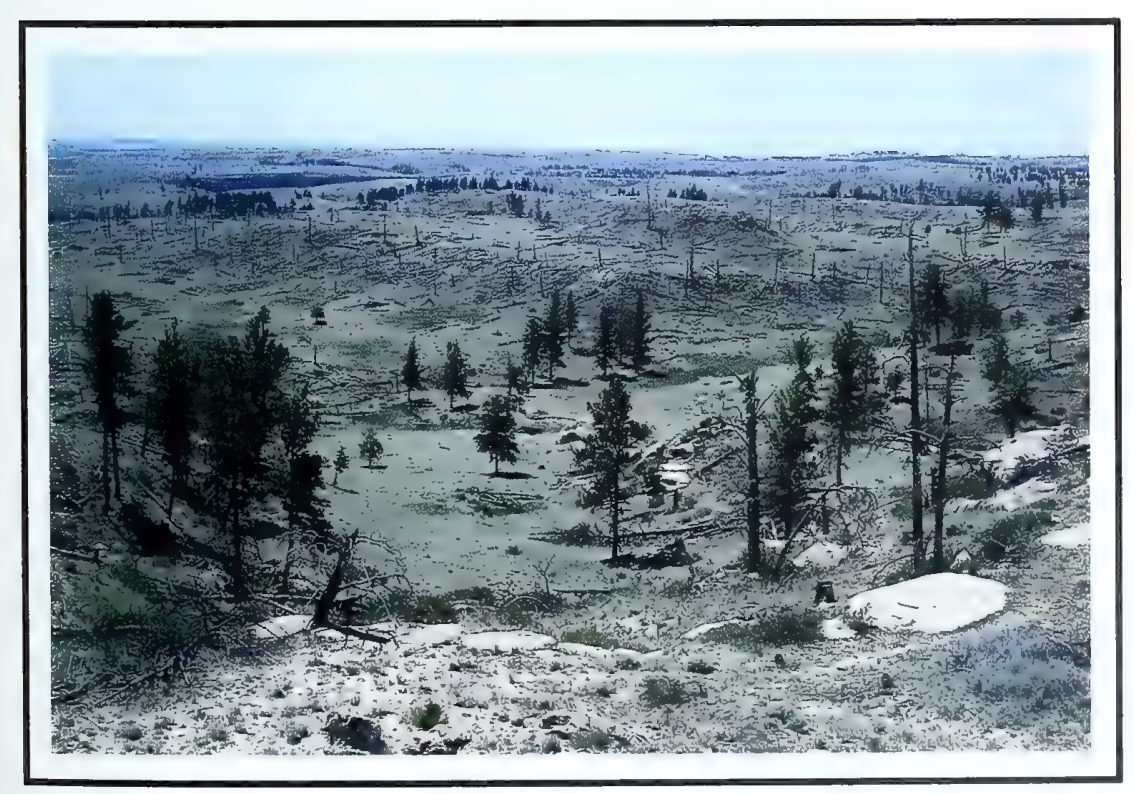

\section{Synopsis}

A fire went through this area in 1984, causing a major decrease of Pinus ponderosa. The ridges in this picture are dominated by shrub species, predominantly Rhus trilobata. Grass is sparse in the foreground but is much more apparent in the lowlands. Agropyron smithii dominates the lowland and upland vegetation. However, Bromus japonicus and Poa pratensis have invaded some localized areas. 


\section{Original Photograph}

August 9, 1918. Shantz T-3-1918. Facing southeast.

\section{First Retake and Description}

June 29, 1959. W.S.P., G-7-1959.

The original grass is Bouteloua gracilis and Agropyron smithii. Small amount of Artemisia spp. in low areas. In the retake the grasses seem about the same but Artemisia spp. has spread considerably and Opuntia spp. is common in the grass. Pinus ponderosa on the bluffs has about the same number of trees, but they are larger. The stump of the farthest tree to the left is still present, although the tree has been cut down (from Phillips 1963, p. 61).

\section{Second Retake}

July 22, 1998.

Kay-4329-33.
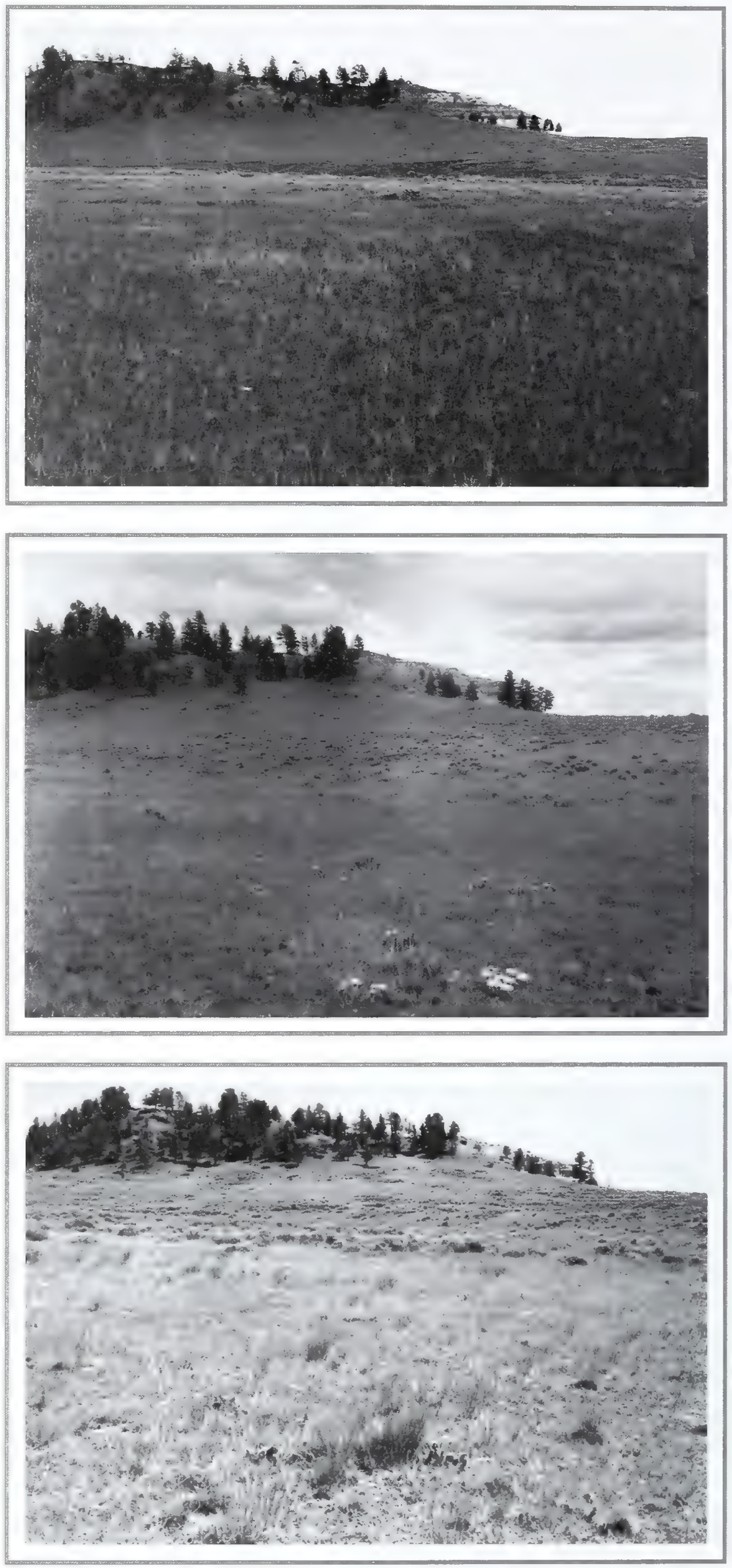


\section{Valentine, Montana}

\section{Location}

Fergus Co., MT; Sec. 16, R. 26 E., T. 18 N.; GPS-UTM 6244564 N, 695746 E.

About 30 miles east of Roy.

From Roy, travel east 7.5 miles on U.S. Highway 191, then south 0.5 mile on Montana Highway 19 to Valentine Road. Turn left (east) onto Valentine Road (gravel road) and continue about 19 miles to intersection of Dovetail Trail Road and Valentine Road. Continue straight (east) on Dovetail Road about 0.3 mile until road turns north. Photopoint is about 350 yards southeast of bend in the road.

\section{Description}

August 10, 1999

\section{Upland Near Photopoint}

Grasses. Agropyron smithii, Bouteloua gracilis, Stipa comata, Stipa viridula, Koeleria cristata, Poa secunda, Calamovilfa longifolia, Bromus japonicus, Agropyron cristatum

Forbs. Sphaeralcea coccinea, Psoralea tenuiflora, Liatris punctata

\section{Drainage to Ridge}

Grasses. Agropyron smithii, Bouteloua gracilis, Stipa comata, Koeleria pyramidata, Poa secunda

Forbs. Sphaeralcea coccinea, Psoralea tenuiflora

Shrubs. Artemisia cana, Artemisia tridentata, Ceratoides lanata, Tetradymia canescens

\section{Synopsis}

The upland in the foreground has been invaded by Agropyron cristatum. Opuntia spp. are still present. Both Artemisia tridentata and $A$. cana have significantly increased in density and size. Although Pinus ponderosa density seems to have increased only slightly, trees have grown in size.

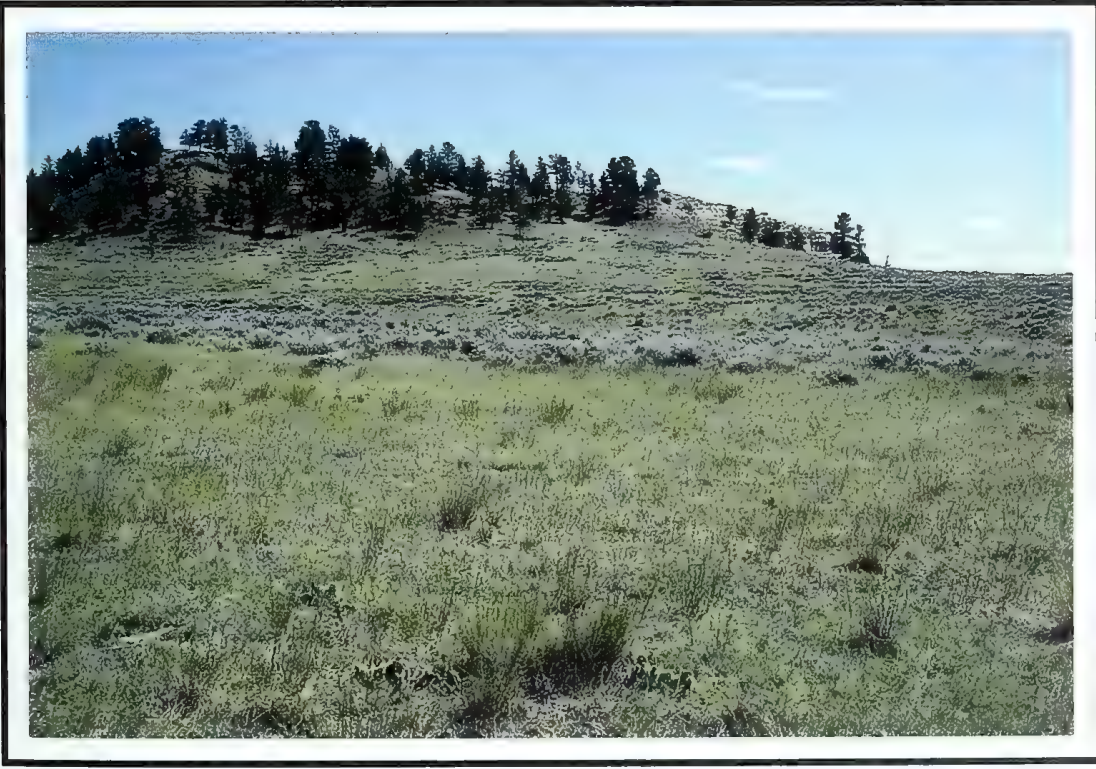




\section{Original Photograph}

August 9, 1918. Shantz

T-5-1918. Facing east.

\section{First Retake and Description}

June 29, 1959. W.S.P., G-9-1959.

Grasses of Agropyron smithii and some Stipa spp. still present. Pinus ponderosa shows some increase in size of individual trees and some reproduction. Original snag in middle foreground still present (from Phillips 1963, p. 63).
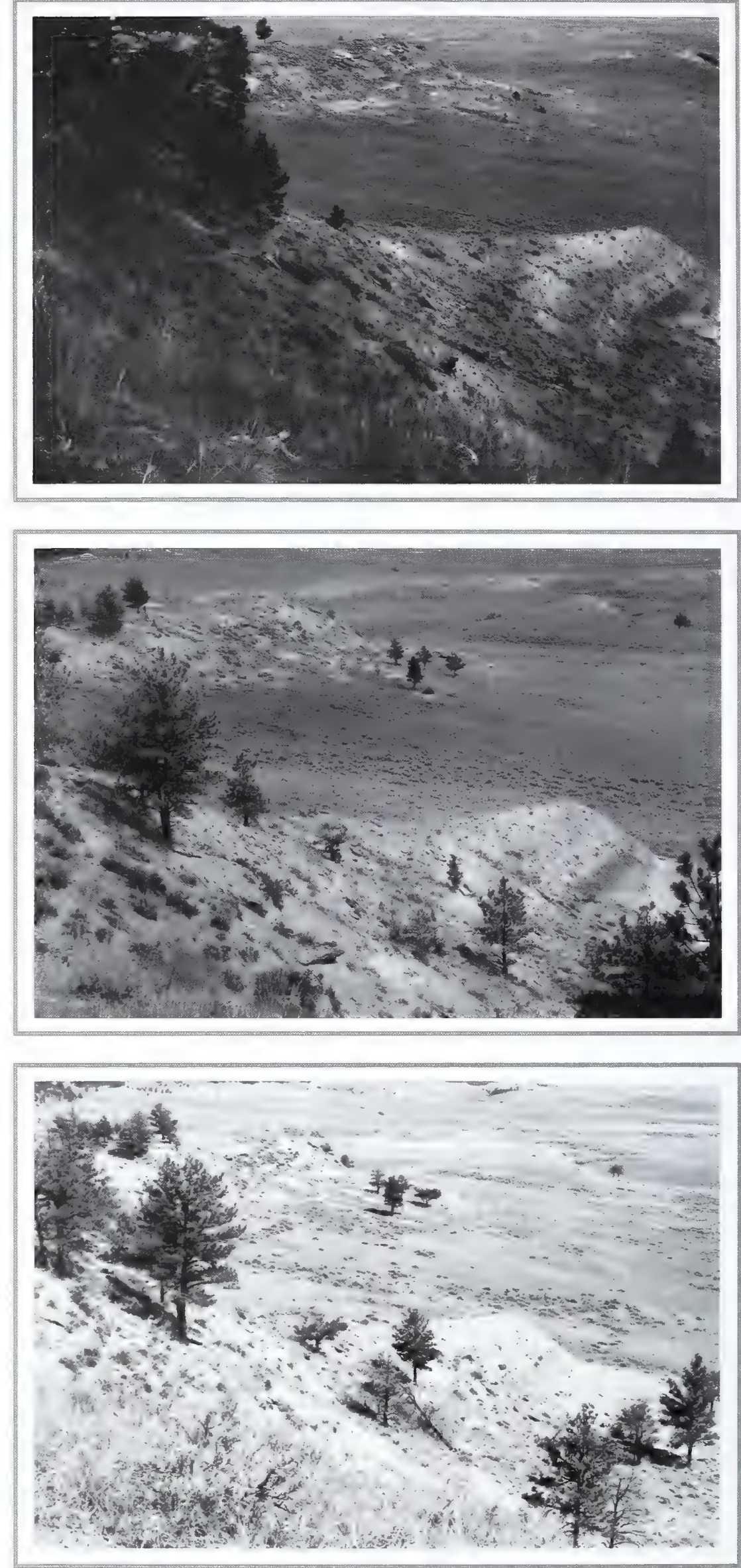


\section{Valentine, Montana}

\section{Location}

Fergus Co., MT; Sec. 16, R. 26 E., T. 18 N.; GPS-UTM 5244386 N, 696118 E.

About 30 miles east of Roy.

From Roy, travel east 7.5 miles on U.S. Highway 191, then south 0.5 mile on Montana Highway 19 to Valentine Road. Turn left (east) onto Valentine Road (gravel road) and continue about 19 miles to intersection of Dovetail Trail Road and Valentine Road. Continue east on Dovetail Road about 0.3 mile until road turns north. Photopoint is from southernmost ridge, located southeast of the intersection of Dovetail Road and Valentine Road, or northeast of Valentine, Montana. Ridge for this photopoint is shown in previous photo set (Valentine, Montana pages 29 and 30).

\section{Description}

August 10, 1999

\section{Near Photopoint and Along Ridge}

Grasses. Calamovilfa longifolia, Oryzopsis hymenoides, Agropyron spicatum, Muhlenbergia cuspidata, Schizachyrium scoparium
Forbs. Solidago spp.

Shrubs. Rhus trilobata, Atriplex confertifolia, Yucca glauca, Artemisia tridentata

\section{Upland Below Ridge}

Grasses. Agropyron smithii, Bouteloua gracilis, Stipa comata, Koeleria pyramidata, Poa secunda

Shrubs. Artemisia tridentata, Artemisia frigida

\section{Synopsis}

Most of the Pinus ponderosa have increased in size. In the bottom center of picture, along the lower end of the slope, two trees have increased in size while two others have died since 1959. Artemisia tridentata now covers a much larger area than before. Near the upper right corner of the 1998 photo, hayfields are apparent. 


\section{Original Photograph}

October 19, 1909. Reproduced black and white slide; Shantz W-61909 missing. Facing west.

\section{First Retake and Description}

August 12, 1960. W.S.P., No. 2390.

The vegetation is mainly Bouteloua gracilis and Bouteloua hirsuta. Carex filifolia amounts to almost one half of the ground cover in many places. Stipa comata and Artemisia filifolia account for most of the other growth. A few plants of Liatris punctata and Psoralea tenuiflora are present. In many places Calamovilfa longifolia is predominant. On the hills in the background are trees of Pinus ponderosa. No particular change in the ecotone between grasses and pines (from Phillips 1963, p. 65).
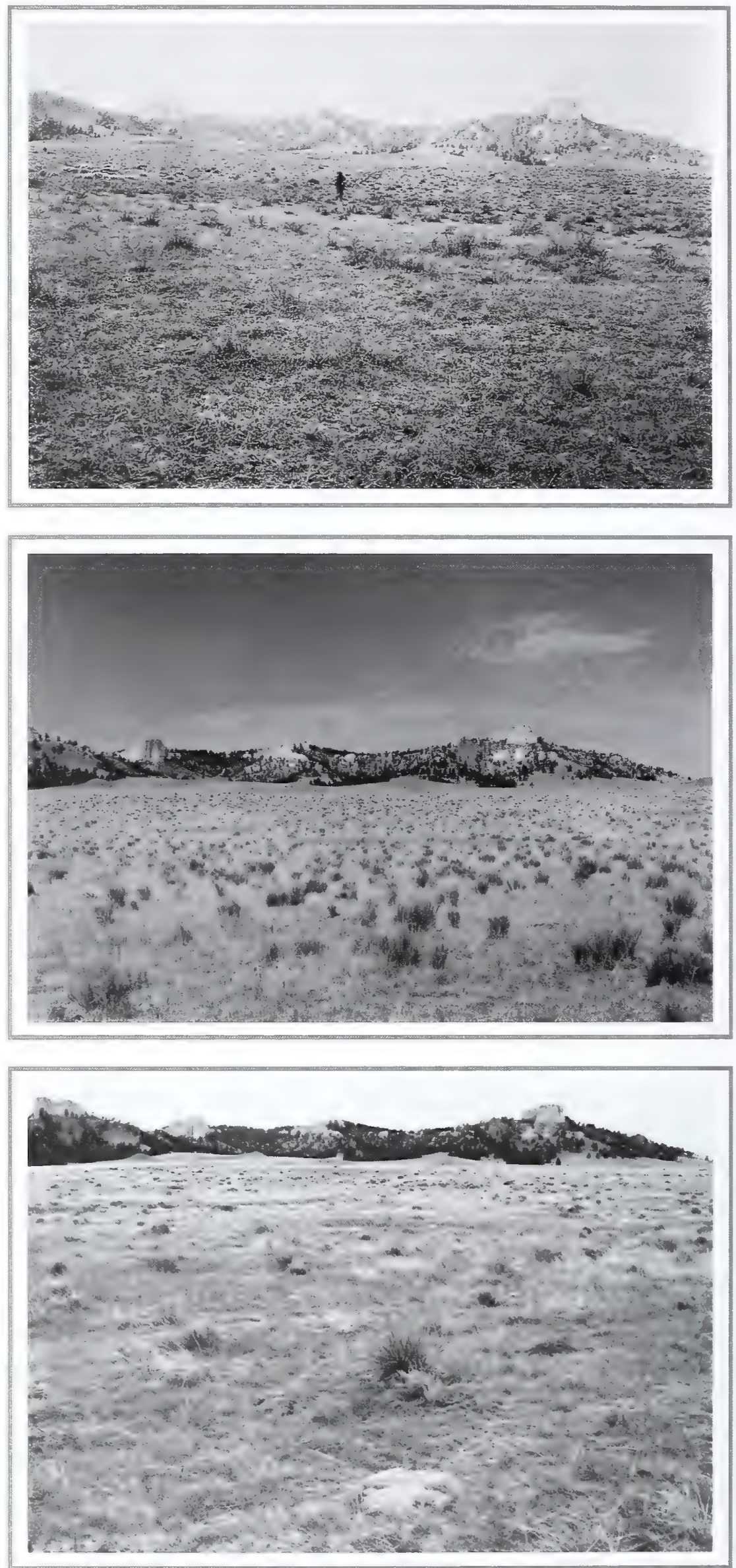


\section{Crawford, Nebraska}

\section{Location}

Dawes Co., NE; Sec. 4, R. 52 W., T. 31 N.; GPS-UTM 4727406 N, 629088 E.

West of Crawford City Park at Ft. Robinson State Park.

From Crawford, at intersection of U.S. Highway 20 and Nebraska Highways 2 and 71, continue west through town to Crawford City Park. Proceed west of city park stadium about 100 yards to Ft. Robinson State Park's fence line. Photopoint is located about 100 yards west of Ft. Robinson State Park's east fence line.

\section{Description}

September 21, 1999

\section{Upland}

Grasses. Carex filifolia, Stipa comata, Bouteloua gracilis, Koeleria pyramidata, Poa secunda, Poa pratensis, Aristida longiseta, Calamovilfa longifolia, Andropogon hallii
Forbs. Liatris punctata, Aster ericoides, Ambrosia psilostachya, Chrysopsis villosa, Erigonium spp., Psoralea tenuiflora

Shrubs. Artemisia filifolia, Yucca glauca

\section{Synopsis}

Composition of plant species is similar to that in 1960 description. Present grass and grasslike composition is estimated as 60 percent Carex, Stipa, and Bouteloua; 30 percent Koeleria, Poa, and Aristida; and 10 percent Calamovilfa and Andropogon. One distinct difference is the absence of the Bouteloua hirsuta recorded in 1960. Density and cover of Pinus ponderosa has continued to steadily increase since 1909. Pocket gopher activity is visible in the 1998 photo. Notes also indicate the presence of horses on this site in 1998. 


\section{Original Photograph}

October 21, 1909.

Shantz X-9-1909.

Facing south.

\section{First Retake and Description}

June 17, 1958. W.S.P., C-12-1958.

This is an excellent location for western extension of eastern trees. The trees here are various species of Guercus, Ulmus, Salix, Populus, and Acer negundo. The shrub in the foreground is Rhus glabra mixed in with this are Pinus ponderosa and Juniperus spp. The creek bed in this photograph has changed considerably. Some of the same trees in the old photograph can be picked out in the new photograph. The vegetation seems much denser in the new picture, but this may be due to the fact that the old picture was taken in October when the deciduous trees had shed some of their leaves (from Phillips 1963, p. 69).

\section{Second Retake}

August 2, 1998. Kay-4354-26.
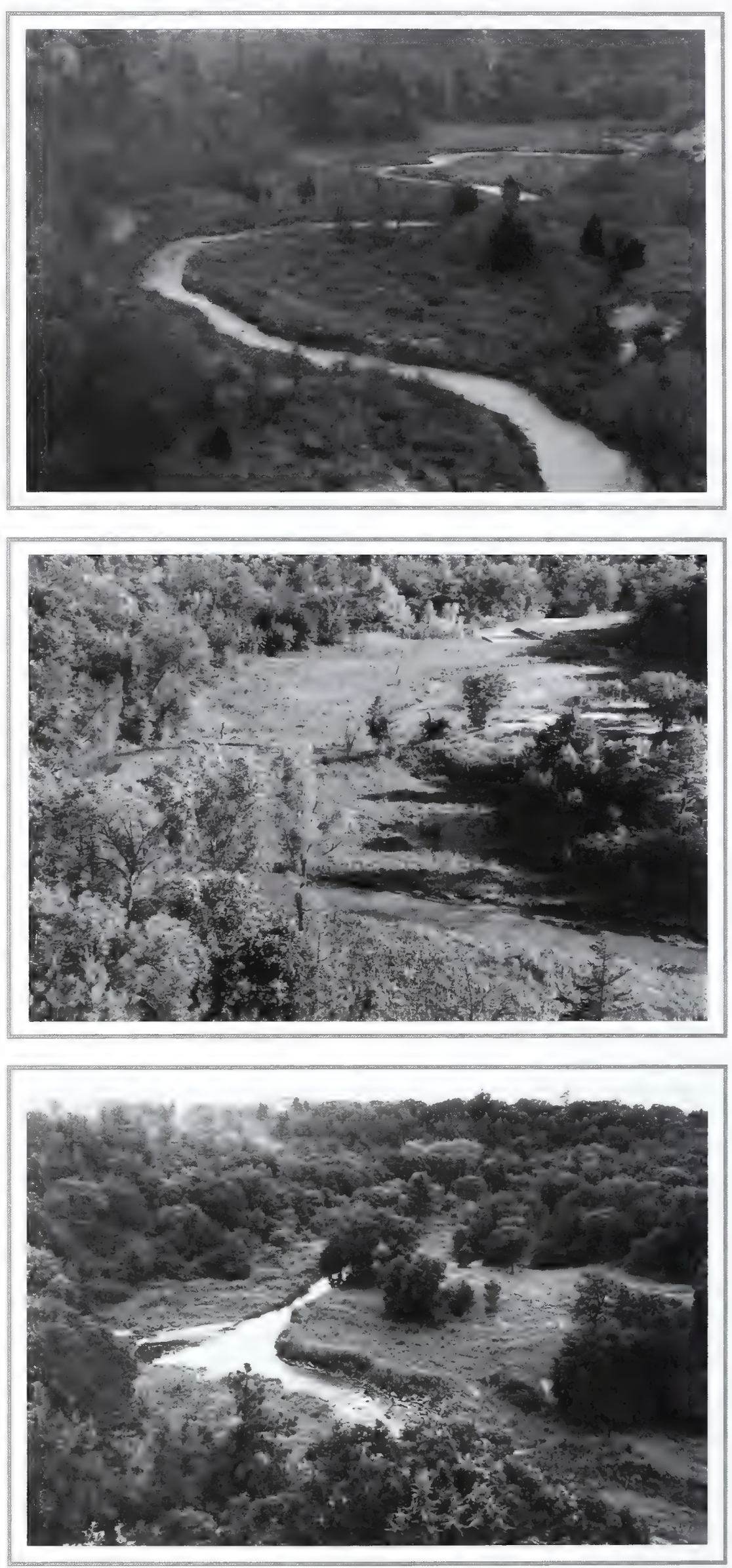


\section{Long Pine, Nebraska}

\section{Location}

Brown Co., NE; Sec. 31, R. 20 W., T. 30 N.; GPS-UTM 4708894 N, 441588 E.

About 1.5 miles south-southwest of Long Pine.

From Long Pine, off U.S. Highway 20, travel south on Main Street and cross a bike path (that is, abandoned railroad tracks) near the center of town. Turn right (west) immediately after crossing the bike path and travel about 0.2 mile to the bridge. Photopoint is from the east end of bridge.

\section{Description}

September 22, 1999

\section{Bottomland and Ridges}

Grasses. Muhlenbergia

racemosa, Panicum

virgatum, Calamovilfa

longifolia, Andropogon

gerardii, Andropogon hallii,

Schizachyrium scoparium,

Bouteloua gracilis,

Dicanthelium spp., Carex

spp.
Forbs. Ambrosia

psilostachya, Aster ericoides, Conyza canadensis, Asclepias spp., Helianthus annuus, Kochia scoparia, Medicago sativa

Trees. Acer negundo, Pinus ponderosa, Populus deltoides, Ulmus americana, Quercus stellata, Juniperus virginiana

\section{Synopsis}

The course of Long Pine Creek has become less meandering since 1908. The 1908 photo shows few shrubs and trees along the watercourse and a narrow meandering creek. Although the 1958 and 1998 retakes show an increase in deciduous and evergreen tree densities and cover, which hide a good portion of the creek, the visible areas reflect a wider and shallower creek. Many seral and invasive species, such as Conyza canadensis, Helianthus annuus, Kochia scoparia, and Ambrosia psilostachya, are currently present.

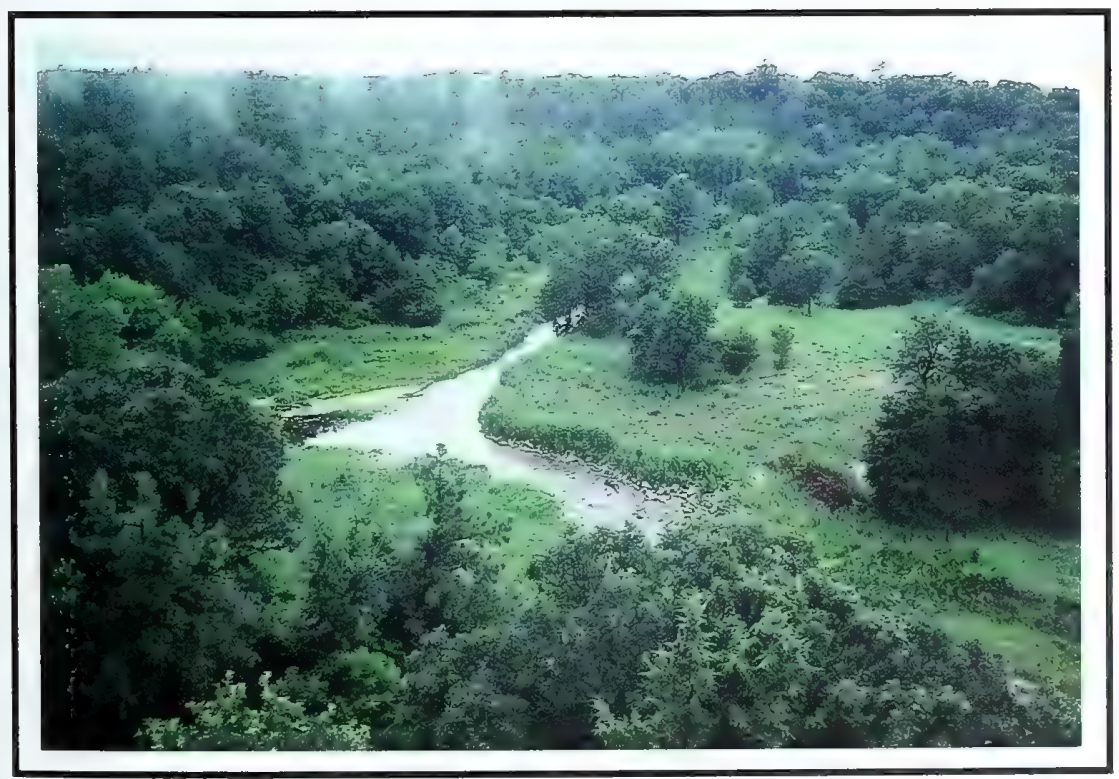




\section{Original Photograph}

September 22, 1924.

Shantz $\mathrm{H}^{2}-2-1924$.

Facing southeast.

First Retake and Description

June 26, 1959. W.S.P., E-10-1959.

This is the left hand end of the panorama and shows the erosion bank. The shrubs in the foreground mainly Symphoricarpos spp. and shruby Cinquefoil. The grasses are mainly Stipa comata, with some Bouteloua spp. The "peaks" on the horizon of the old picture are haystacks (from Phillips 1963, p. 75).

Second Retake

July 30, 1998.

Kay-4346-24A.
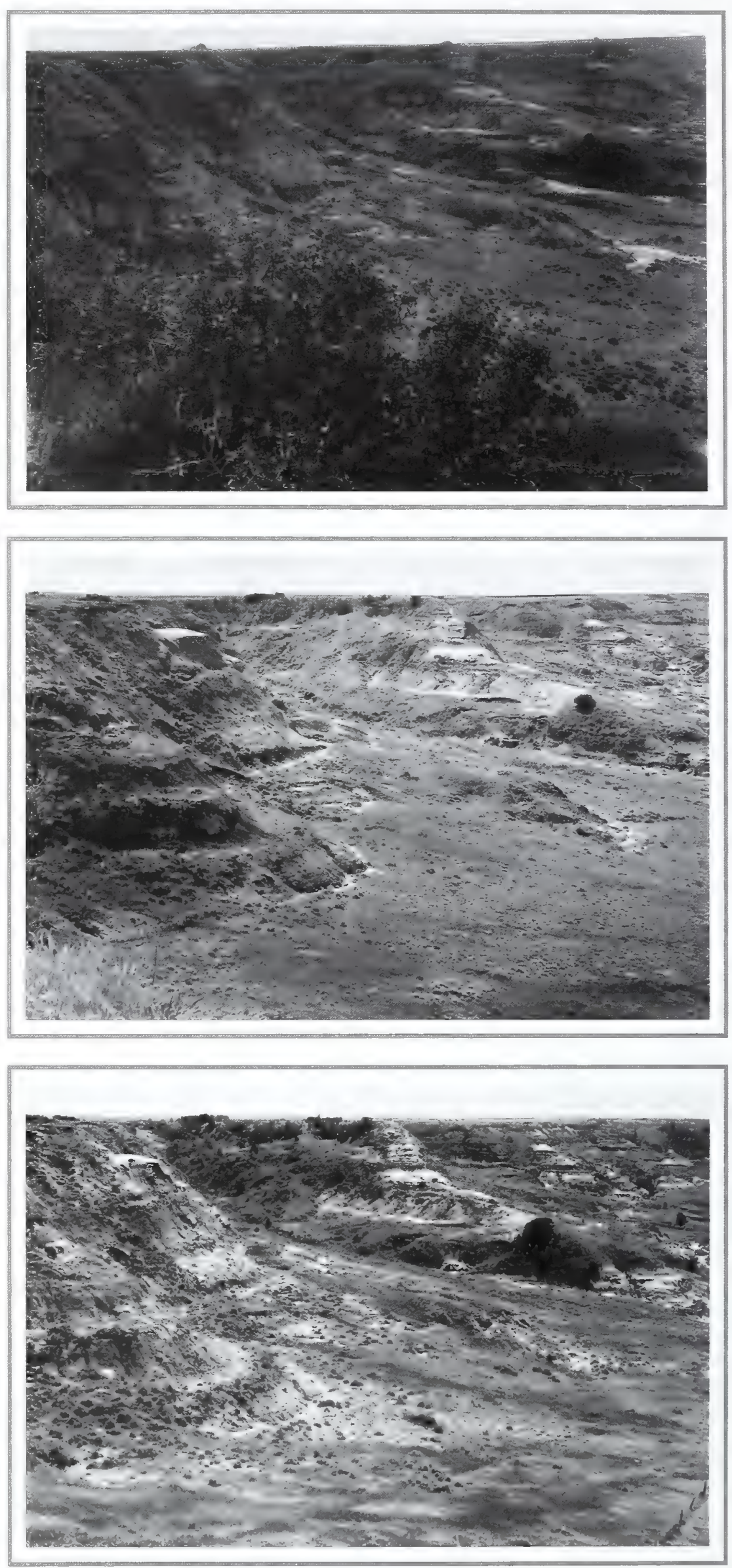


\section{Fryburg, North Dakota}

\section{Location}

Billings Co., ND; Sec. 18, R. 100 W., T. 139 N.; GPS-UTM 5191143 N, 625999 E.

About 2 miles west-southwest of Fryburg.

From Medora, South Dakota, travel 13 miles east on U.S. Interstate 94. Take Exit 36 and turn right (south). Continue through Fryburg to "T" in road, located about 0.4 mile south of town. Turn right (west) onto Sully Creek Road and travel 2 miles. Photopoint is about 30 yards south of the road.

\section{Description}

August 27, 1999

\section{Bottomland}

Grasses. Agropyron cristatum, Agropyron smithii

Forbs. Kochia scoparia, Sphaeralcea coccinea, Psoralea tenuiflora, Artemisia ludoviciana

\section{Hills, Ridgetops, Upper Plateaus}

Grasses. Agropyron smithii, Bouteloua gracilis, Stipa comata, Calamovilfa longifolia

Shrubs and Trees. Artemisia cana, Artemisia tridentata, Artemisia frigida, Rhus trilobata Juniperus communis, Juniperus scopulorum, Fraxinus pennsylvanica

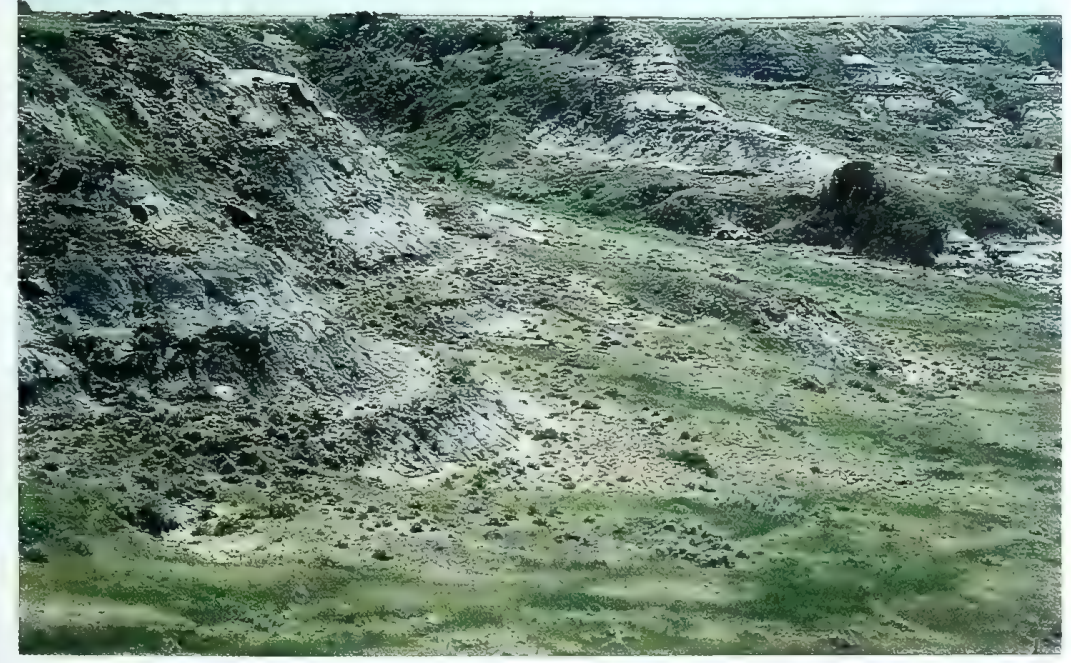

\section{Synopsis}

Much of the native range has been cultivated on the upper plateaus (note the round hay bales in upper center of 1998 photo). A haystack yard fence is visible in the bottom right corner of the 1998 photo. Kochia scoparia and Agropyron cristatum are abundant inside the stack yard. The shrubs (look to be Shepherdia argentea) in immediate foreground of 1924 photo had been removed by the 1959 retake. Size of Artemisia spp. and Juniperus spp. have increased since 1924 


\section{Original Photograph}

September 22, 1924.

Shantz H²-4-1924.

Facing south.

\section{First Retake and Description}

June 26, 1959. W.S.P., E-12-1959.

Very little change in this. The trees mainly pines on the hill in the center are about the same. Two dirt tanks have been built in the background to the right. Erosion has not changed much (from Phillips 1963, p. 77).
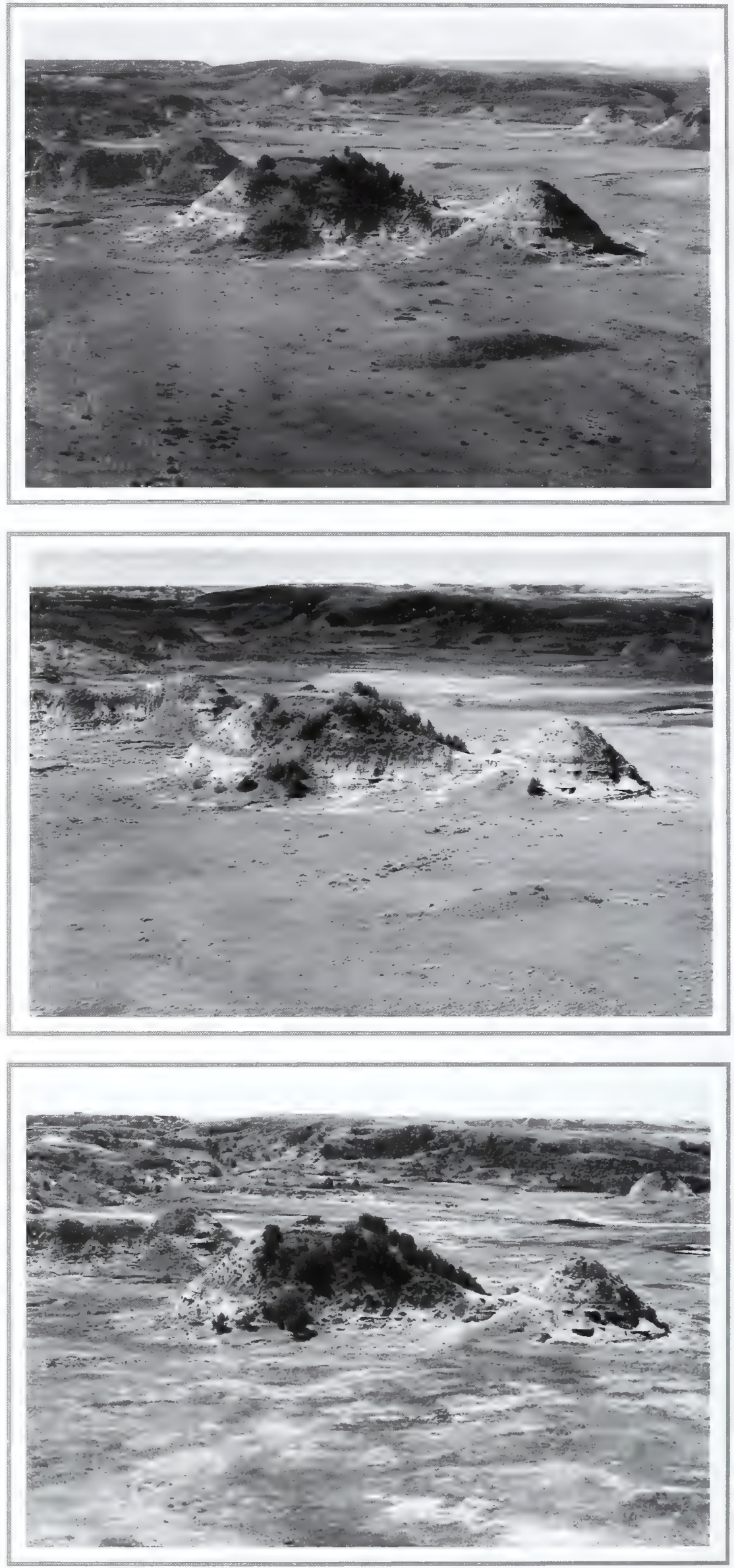


\section{Fryburg, North Dakota}

\section{Location}

Billings Co., ND; Sec. 18, R. 100 W., T. 139 N.; GPS-UTM 5191143 N, 625999 E.

About 2 miles west-southwest of Fryburg.

From Medora, South Dakota, travel 13 miles east on U.S. Interstate 94. Take Exit 36 and turn right (south). Continue through Fryburg to "T" in road, located about 0.4 mile south of town. Turn right (west) onto Sully Creek Road and travel 2 miles. Photopoint is about 30 yards south of the road.

\section{Description}

August 27, 1999

\section{Bottomland}

Grasses. Agropyron

cristatum, Agropyron smithii, Hordeum jubatum

Forbs. Kochia scoparia, Sphaeralcea coccinea, Psoralea tenuiflora, Artemisia ludoviciana

\section{Hills, Ridgetops, Upper Plateaus}

Grasses. Agropyron smithii, Bouteloua gracilis, Stipa comata, Calamovilfa longifolia

Shrubs and Trees. Artemisia cana, Artemisia tridentata, Artemisia frigida, Rhus trilobata, Juniperus communis, Juniperus scopulorum, Fraxinus pennsylvanica

\section{Synopsis}

Similar to "Fryburg, North Dakota (page 37)," as much of the upland native range has been converted to cropland on the upper plateaus. Bottomland vegetation previously dominated by Bouteloua gracilis and Agropyron smithii, is mostly Agropyron cristatum, Hordeum jubatum, and Kochia scoparia. The pine trees discussed in the 1959 description are actually junipers (Juniperus spp.).

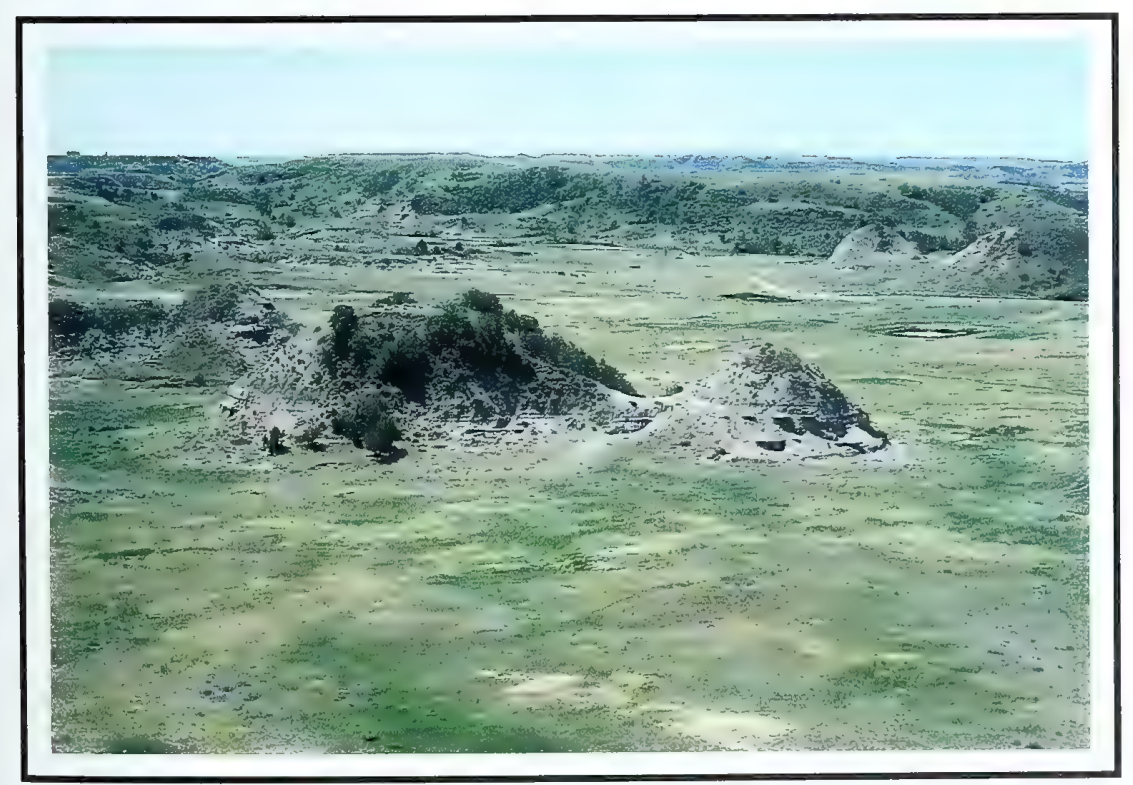




\section{Original Photograph}

September 22, 1924.

Shantz G ${ }^{2}-8-1924$.

Facing north.

\section{First Retake and Description}

June 25, 1959. W.S.P., E-4-1959.

Dr. Shantz had taken a series of about ten pictures in this area within a distance of about fifty feet. The area is a dry water course with some watering holes for cattle. The grasses here are Stipa comata and Bouteloua gracilis with some Andropogon scoparius. The shrubs are mainly Shepherdia canadensis and Symphoricarpos spp. In the new picture the tree growth has increased. The large tree in the center is Fraxinus spp., and the shrubs are the same as the original picture except for Prunus spp. which Dr. Shantz does not mention. The Microwave Station was in the middle distance (from Phillips 1963, p. 79).

\section{Second Retake}

July 30, 1998.

Kay-4346-9A.
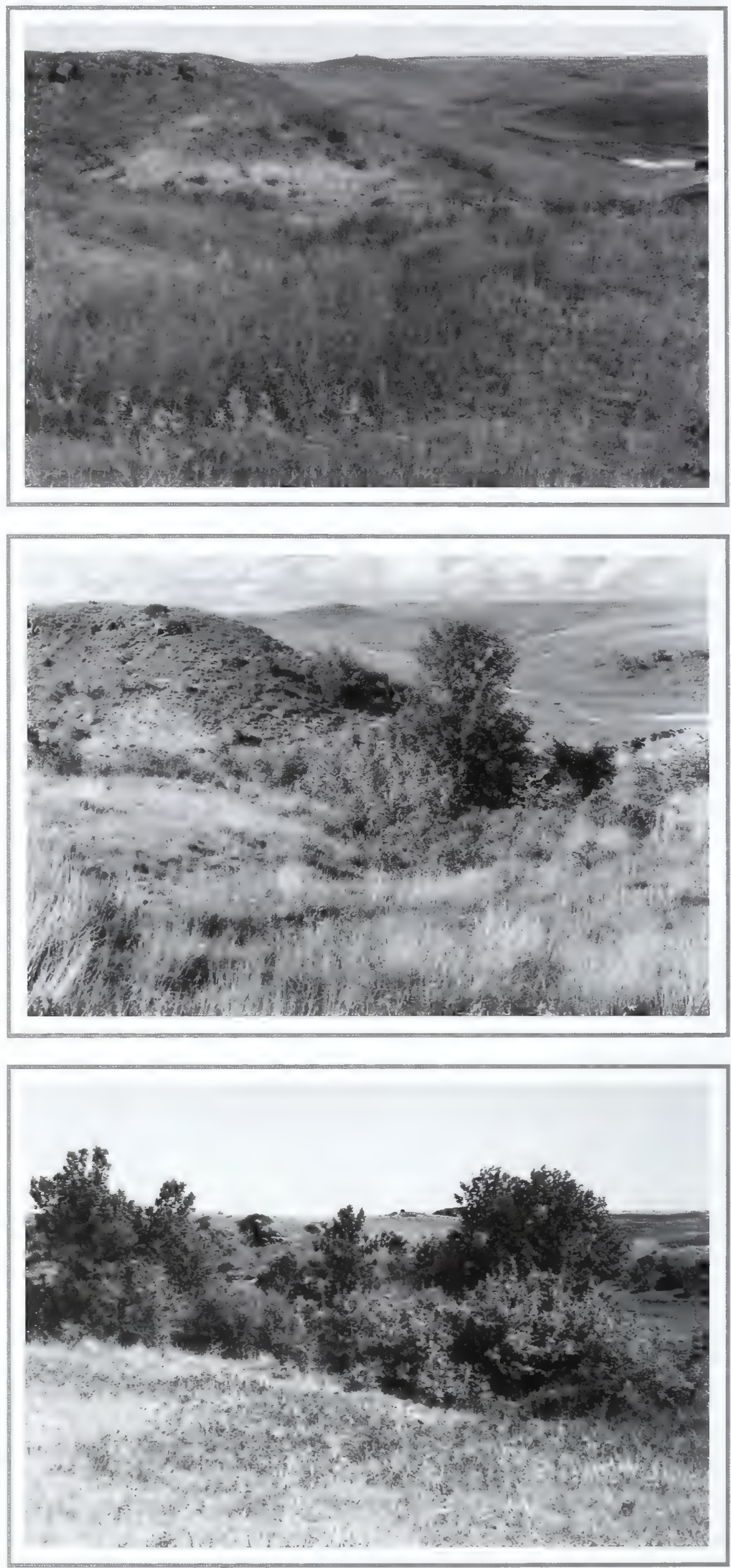


\section{Fryburg, North Dakota}

\section{Location}

Billings Co., ND; Sec. 8, R. 100 W., T. 139 N.; GPS-UTM 5191148 N, 627345 E.

About 1.3 miles west-southwest of Fryburg.

From Medora, South Dakota, travel 13 miles east on U.S. Interstate 94. Take Exit 36 and turn right (south). Continue through Fryburg to "T" in road, located about 0.4 mile south of town. Turn right (west) onto Sully Creek Road and travel 1.3 miles. Photopoint is in a swale about 50 yards north of the road.

\section{Description}

August 27, 1999

\section{Upland and Hillsides}

Grasses. Agropyron smithii, Koeleria pyramidata, Stipa comata, Poa pratensis, Bouteloua gracilis, Poa secunda

Forbs. Chrysopsis villosa, Solidago spp., Psoralea tenuiflora, Artemisia ludoviciana
Shrubs. Artemisia dracunculus, Artemisia frigida, Symphoricarpos occidentalis

\section{Drainage}

Shrubs and Trees.

Shepherdia argentea, Prunus virginiana, Potentilla fruticosa, Fraxinus pennsylvanica

\section{Synopsis}

Uplands and hillsides dominated by grasses in 1924 are now rich in shrub and tree species. Since 1924, shrub height and volume has increased greatly; otherwise, since 1959, the composition of herbaceous and woody species appears to have changed little. 


\section{Original Photograph}

September 22, 1924.

Shantz G ${ }^{2}-12-1924$.

Facing northwest.

\section{First Retake and Description}

June 25, 1959. W.S.P., E-5-1959.

This shows the recovery of an eroded stream bank. The shrubs are mainly Fraxinus spp. and Prunus spp. (from Phillips 1963, p. 81).

\section{Second Retake}

July 30, 1998.

Kay-4346-14A.
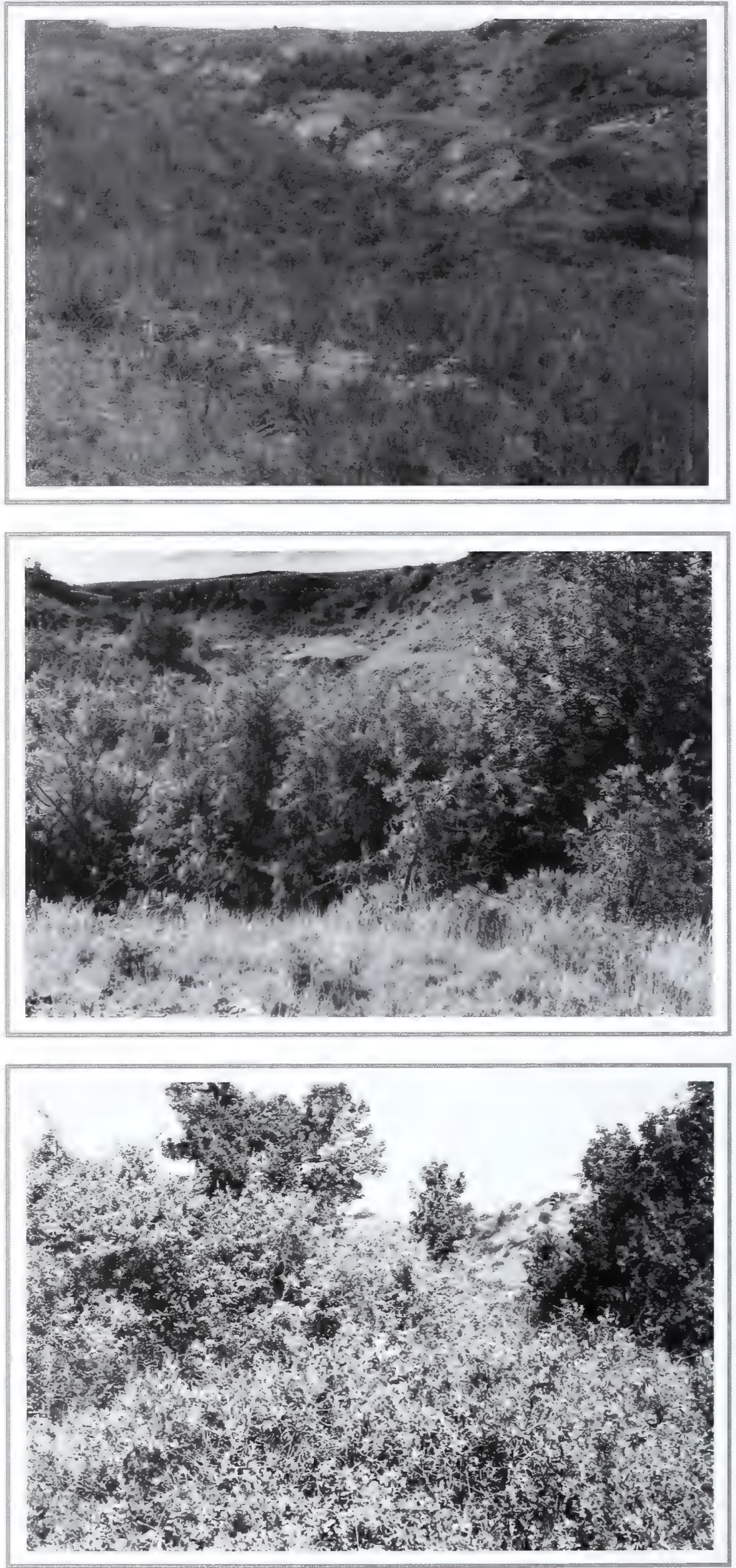


\section{Fryburg, North Dakota}

\section{Location}

Billings Co., ND; Sec. 8, R. 100 W., T. 139 N.; GPS-UTM 5191175 N, 627347 E.

About 1.3 miles west-southwest of Fryburg.

From Medora, South Dakota, travel 13 miles east on U.S. Interstate 94. Take Exit 36 and turn right (south). Continue through Fryburg to "T" in road, located about 0.4 mile south of town. Turn right (west) onto Sully Creek Road and travel 1.3 miles. Photopoint is in a swale about 50 yards north of the road.

\section{Description}

August 27, 1999

\section{Near Photopoint}

\section{Shrubs and Trees.}

Shepherdia argentea, Prunus virginiana, Rhus trilobata,

Potentilla fruticosa, Fraxinus pennsylvanica

\section{Hills}

Shrubs and Trees. Rhus trilobata, Artemisia frigida, Fraxinus pennsylvanica

\section{Synopsis}

Since 1924, a community once dominated by grass now shows a dramatic increase in the size and density of woody species.

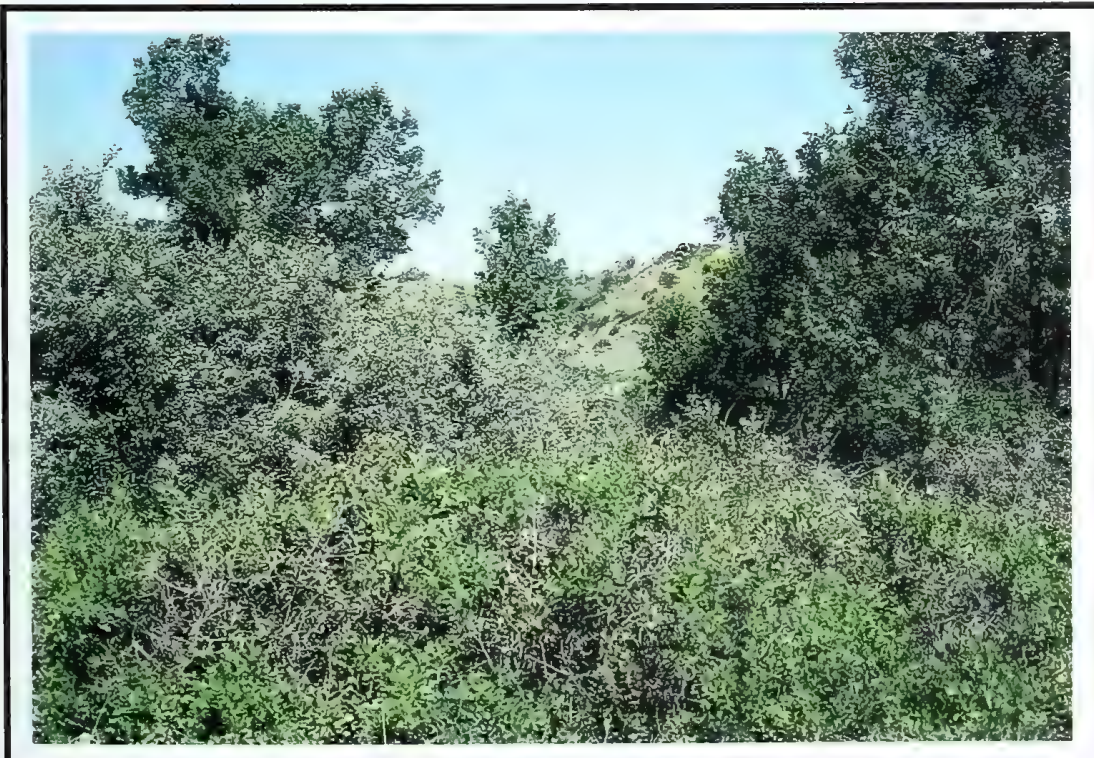




\section{Original Photograph}

July 19, 1927. Shantz

V-10-1927.

Facing north.

\section{First Retake and Description}

June 19, 1959. W.S.P., B-6-1959.

These two photographs illustrate how little change can occur over a long period of time in some of the more arid sites. The main plant is Atriplex nuttallii. A small amount of grass visible in the mid picture is one of the wheat grasses (Agropyron smithii) and shows in both photographs (from Phillips 1963, p. 91).
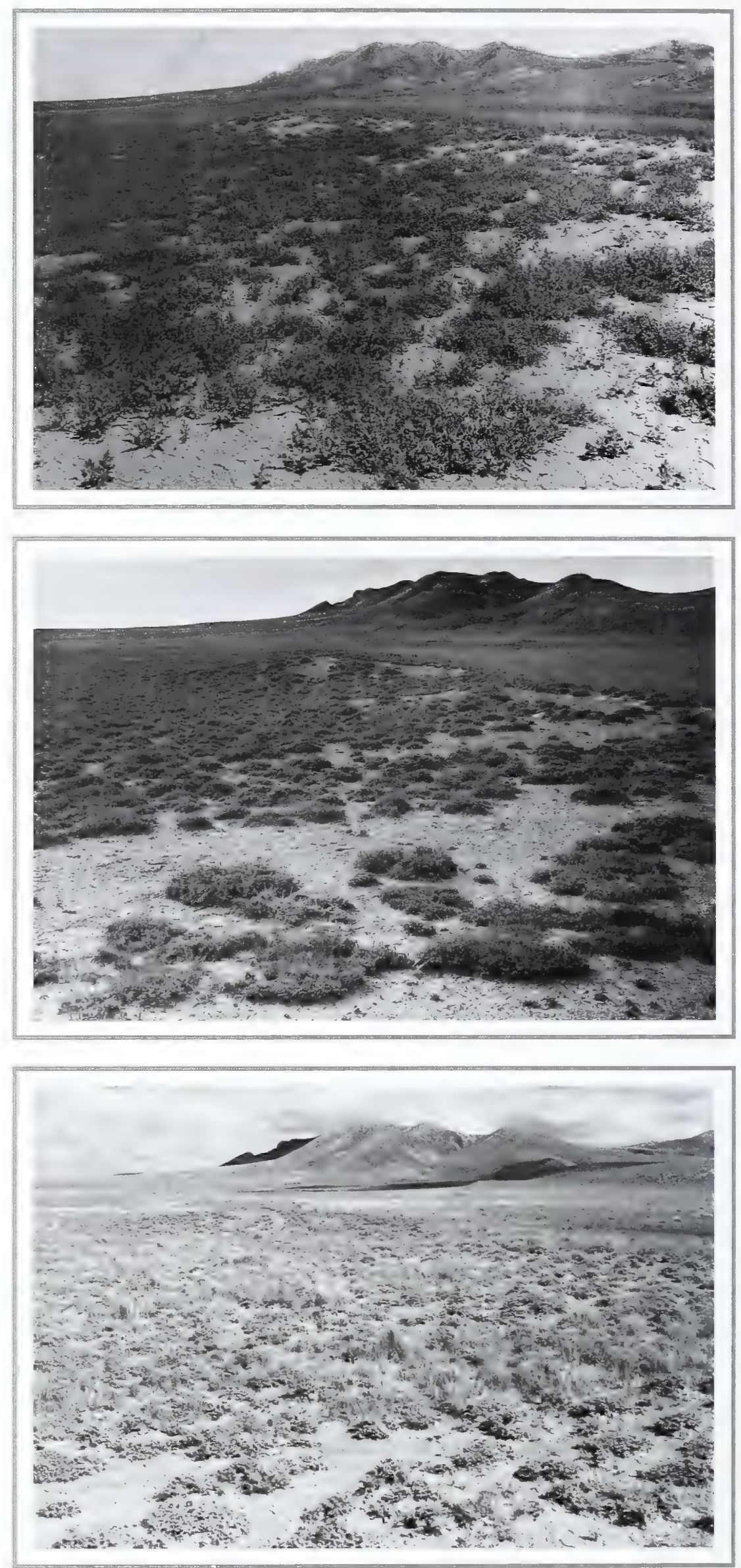


\section{Belle Fourche, South Dakota}

\section{Location}

Butte Co., SD; Sec. 6, R. 3 E., T. 10 N.; GPS-UTM 4968196 N, 593644 E.

About 14.2 miles north-northeast of Belle Fourche.

From Belle Fourche, travel north 14.2 miles along U.S. Highway 85. Photopoint is 50 yards north of the highway.

\section{Description}

September 20, 1999

\section{Shrub-Dominated Upland}

Shrubs. Atriplex nuttallii

\section{Upland Before Hills}

Grasses. Agropyron smithii, Koeleria pyramidata, Agropyron cristatum

Forbs. Melilotus officinalis

Shrubs. Atriplex nuttallii, Sarcobatus vermiculatus, Artemisia tridentata

\section{Synopsis}

Vegetation structure and composition appear to have changed little since 1927 , although a noticeable increase has occurred in density of Atriplex nuttallii. More grass plants (Agropyron cristatum) are visible in 1998 than the previous two photos. Melilotus officinalis is also present.

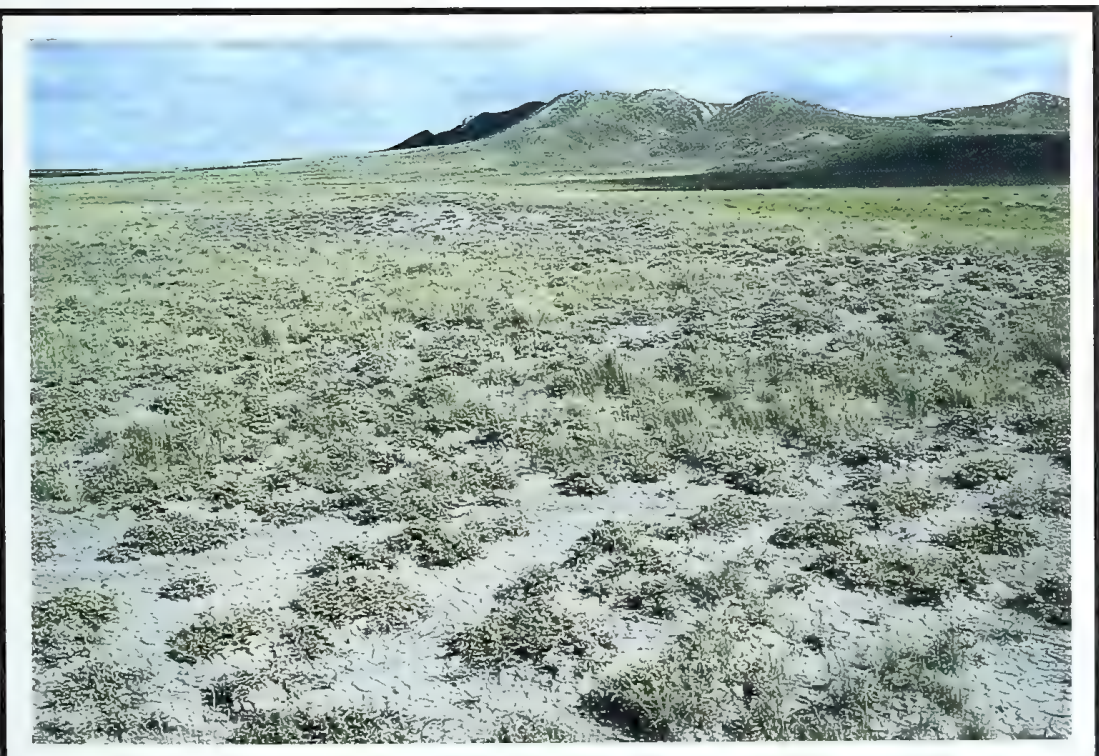




\section{Original Photograph}

July 3, 1927. Shantz

P-12-1927. Facing

northeast.

\section{First Retake and Description}

June 16, 1958. W.S.P., C-5-1958.

This picture and others from the same region illustrates minimal erosion effects. The cliffs were little changed and even the same ridges can be seen in both photographs. Probably the erosion is extremely slow and apt to be catastrophic. The sod of short grass plants holds the surface firmly in place. Notice along the top of erosion bank, colonies of Opuntia spp., an indication that this plant comes into unoccupied grass areas (from Phillips 1963, p. 93).

\section{Second Retake}

August 2, 1998.

Kay-4356-14A.
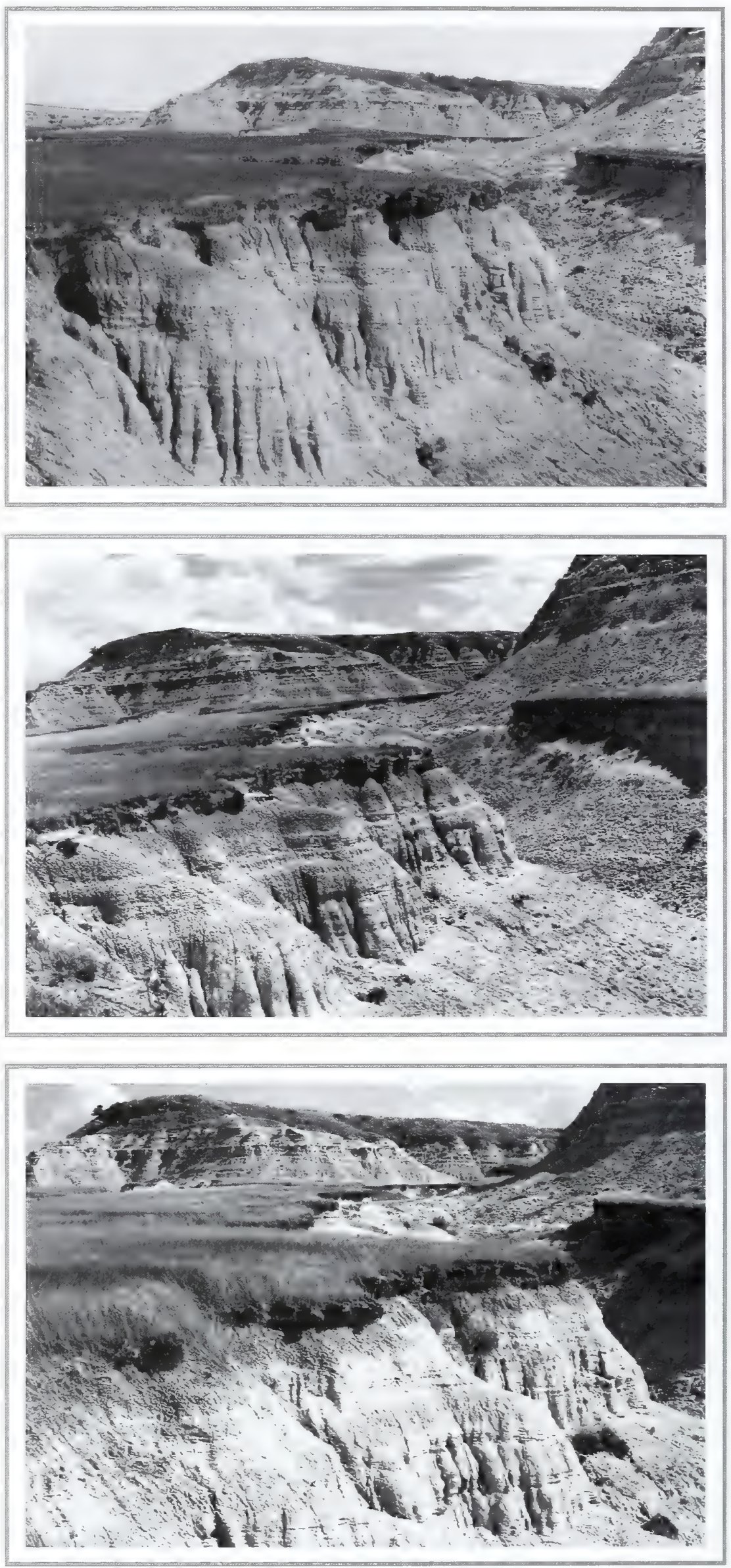


\section{Belvidere, South Dakota}

\section{Location}

Jackson Co., SD; Sec. 36, R. 33 W., T. 43 N.; GPS-UTM 4835468 N, 323562 E.

About 17 miles south-southeast of Belvidere.

From Belvidere, at the intersection of U.S. Interstate 90 and South Dakota Highway 63, travel about 17 miles south to milepost 61.5. Photopoint is located about 150 yards southeast of the road and milepost marker.

\section{Description}

September 22, 1999

\section{Upland Flats and Ridgetops}

Grasses. Agropyron smithii, Bouteloua gracilis, Stipa comata, Calamovilfa longifolia, Schizachyrium scoparium, Bouteloua curtipendula

Forbs. Melilotus officinalis, Opuntia polycantha

\section{Synopsis}

Vegetation composition appears to have changed little since 1927 other than a possible decline in the density of Opuntia polycantha. Agropyron smithii is the overwhelmingly dominant grass species.

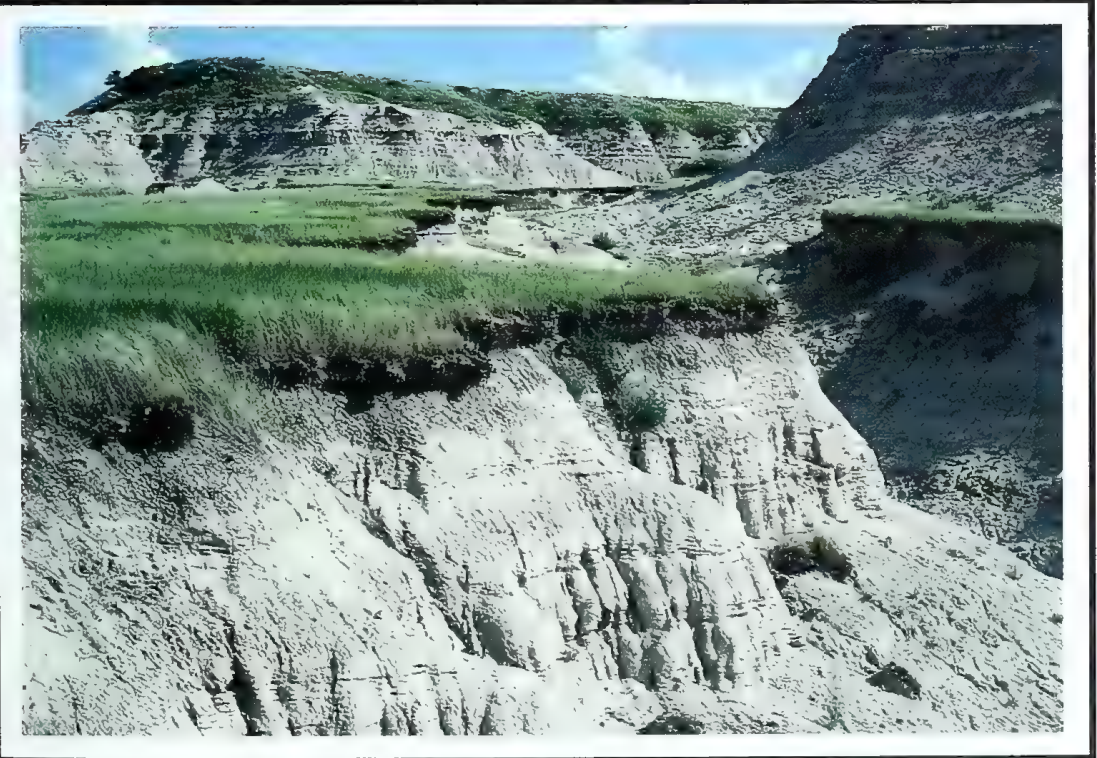




\section{Original Photograph}

July 3, 1927. Shantz

P-10-1927. Facing

northeast.

\section{First Retake and Description}

June 16, 1958. W.S.P., C-6-1958.

This is a typical area of short grass plains. There has been very little change over the period of the two pictures and the same grasses are present in both pictures. The main plants are Bouteloua spp., Stipa comata and Aristida spp. (from Phillips 1963, p. 95).
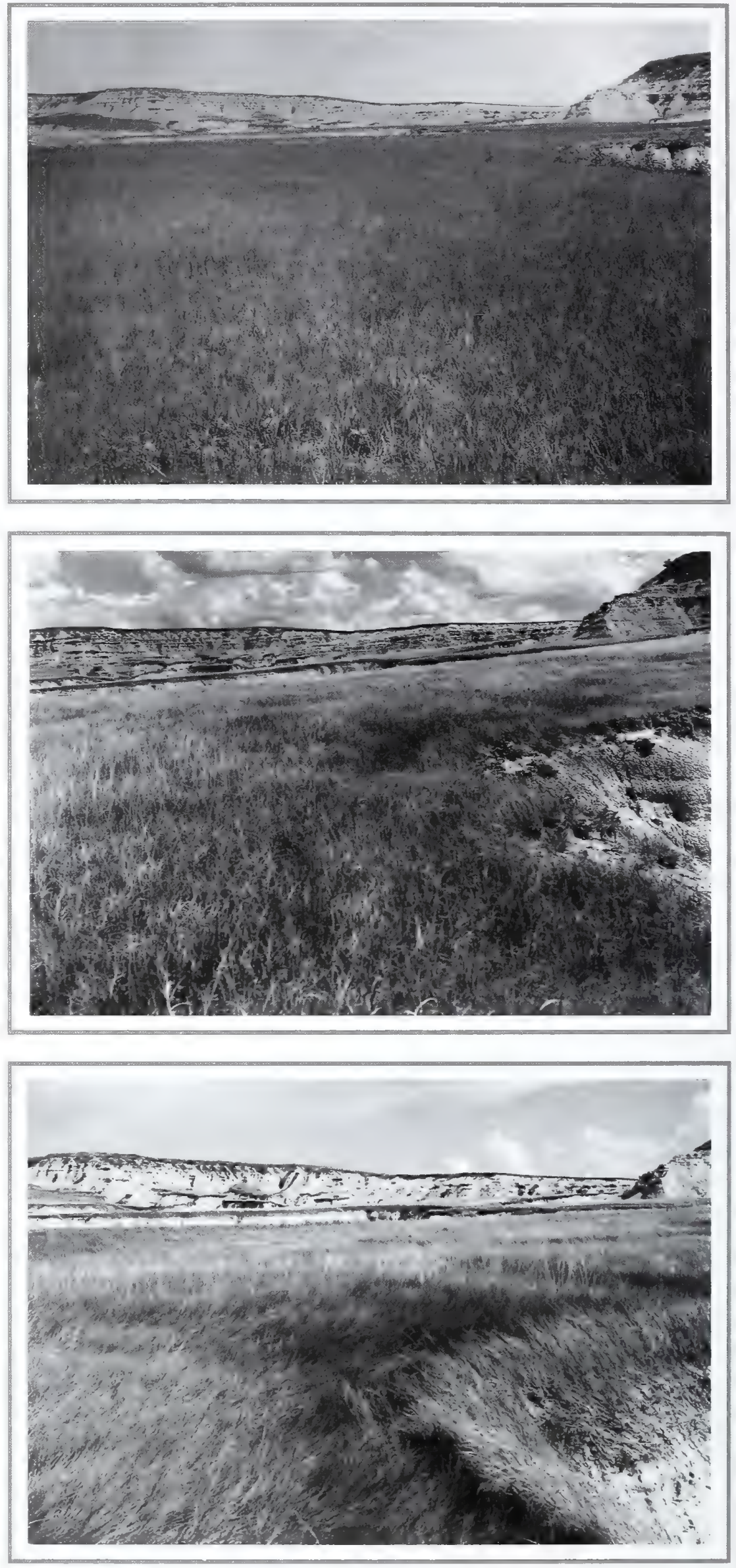


\section{Belvidere, South Dakota}

\section{Location}

Jackson Co., SD; Sec. 36, R. 33 W., T. 43 N.; GPS-UTM 4835468 N, 323562 E.

About 17 miles south-southeast of Belvidere.

From Belvidere, at the intersection of U.S. Interstate 90 and South Dakota Highway 63, travel about 17 miles south to milepost 61.5. Photopoint is located about 150 yards southeast of the road and milepost marker.

\section{Description}

September 22, 1999

\section{Upland Flats and Ridgetops}

Grasses. Agropyron smithii, Bouteloua gracilis, Stipa comata, Calamovilfa longifolia

Forbs. Melilotus officinalis, Opuntia polycantha

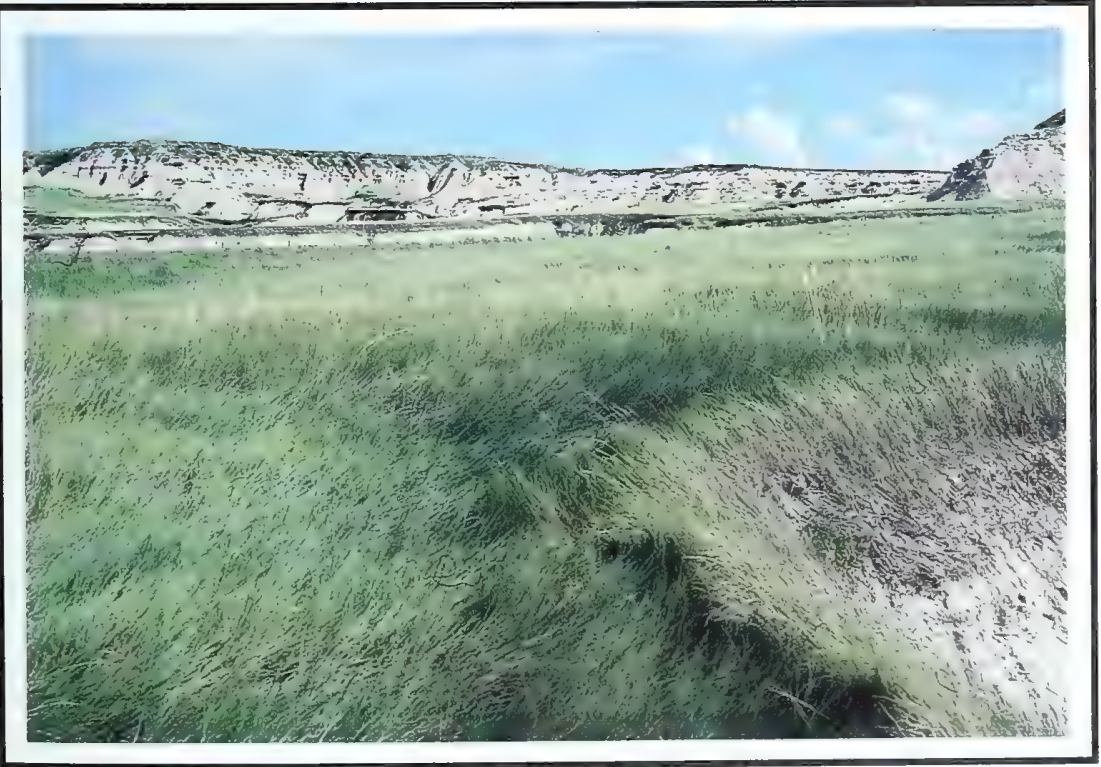

\section{Synopsis}

Vegetation structure appears to have changed little since 1927 other than some decline in the density of Opuntia polycantha. In contrast to the 1959 description, Agropyron smithil is now the overwhelmingly dominant grass species. We also suspect, based on the 1959 photo as opposed to the written description, that it was quite abundant then as well. 


\section{Original Photograph}

July 15, 1927. Shantz

X-10-1927. Facing

southeast.

\section{First Retake and Description}

June 30, 1958. W.S.P., D-8-1958.

Forest mainly of Ponderosa pines shows remarkable recovery. Agropyron smithii is still the dominant plant in both pictures, however, the 1927 photograph shows much Psoralea tenuiflora. This plant was rare when the photograph was retaken and found only along the roadside. Melilotus officinalis and Bromus tectorum were common throughout this area, although they are not mentioned in Dr. Shantz' original notes. The shrubs under the trees are Rosa spp. (from Phillips 1963, p. 99).

\section{Second Retake}

August 4, 1998.

Kay-4358-19.
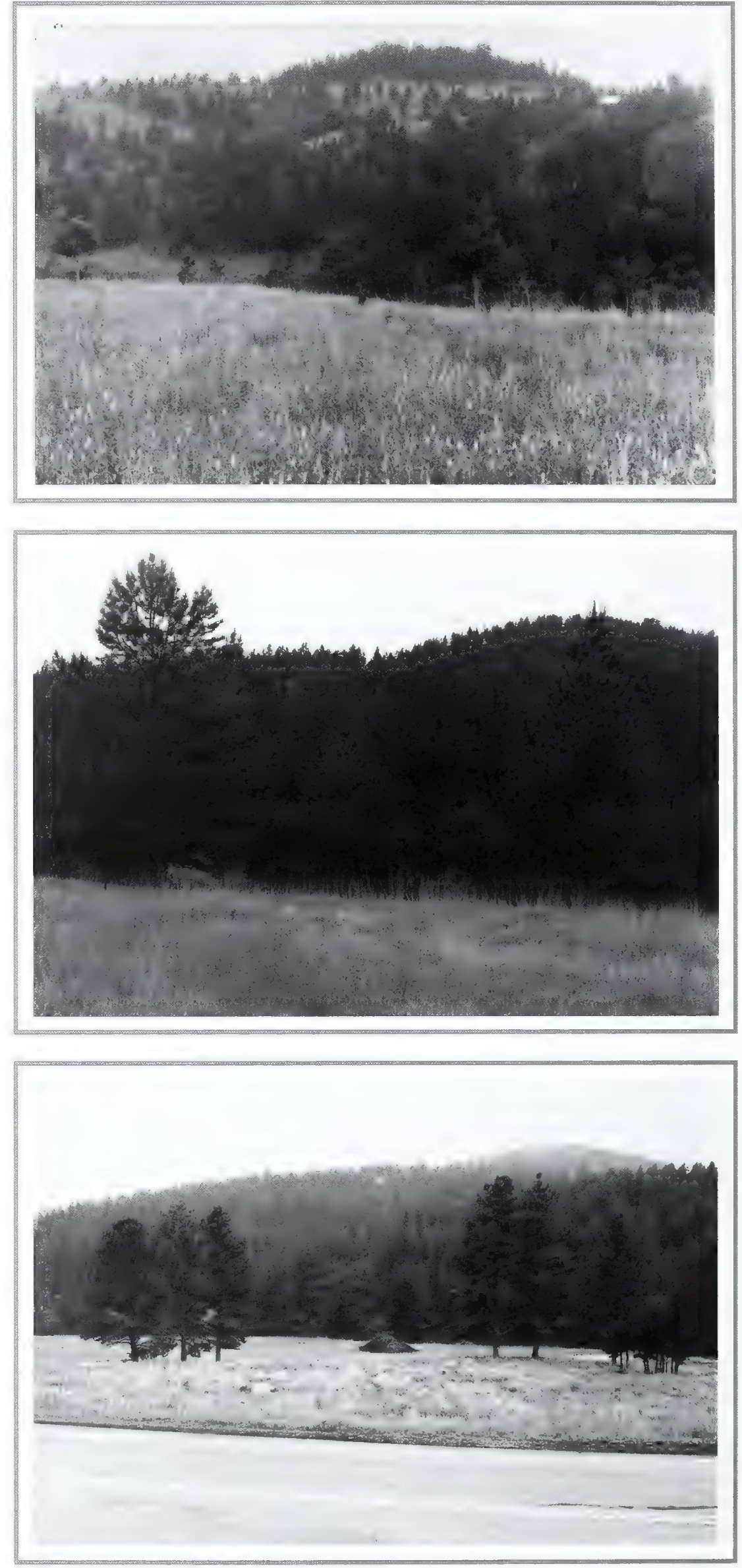


\section{Custer State Park, South Dakota}

\section{Location}

Custer Co., SD; Sec. 25, R. 6 E., T. 3 S.; GPS-UTM 4847163 N, 633332 E (of roadside turnout).

About 11 miles west-southwest of Hermosa.

From Hermosa, South Dakota, continue south on South Dakota Highway 79 about 1 mile to junction of South Dakota Highway 36. Turn right (west) onto South Dakota Highway 36 and travel about 10 miles to the Custer State Park entrance station. From entrance of park, continue west on South Dakota Highway 36 about 0.4 mile. Photopoint is near a left-of-road (south) gravel turnoff. Photopoint is also 2.2 miles east of Custer State Park Game Lodge on South Dakota Highway 36.

\section{Description}

September 21, 1999

\section{Open Grassland Park}

Grasses. Agropyron smithii, Andropogon gerardii, Poa secunda, Poa pratensis
Forbs. Ambrosia psilostachya, Grindelia squarrosa, Artemisia ludoviciana, Solidago spp. Echinacea angustifolia, Vervain spp.

Shrubs and Trees. Rosa woodsii, Symphoricarpos occidentalis, Pinus ponderosa

\section{Synopsis}

A very diverse vegetation complex, but Psoralea tenuiflora was considered rare in 1927 and it was absent in 1999. Agropyron smithii remains the overwhelming dominant. Density and size of Pinus ponderosa trees have continued to increase. Highway and roadside parking area have been realigned since 1958 .

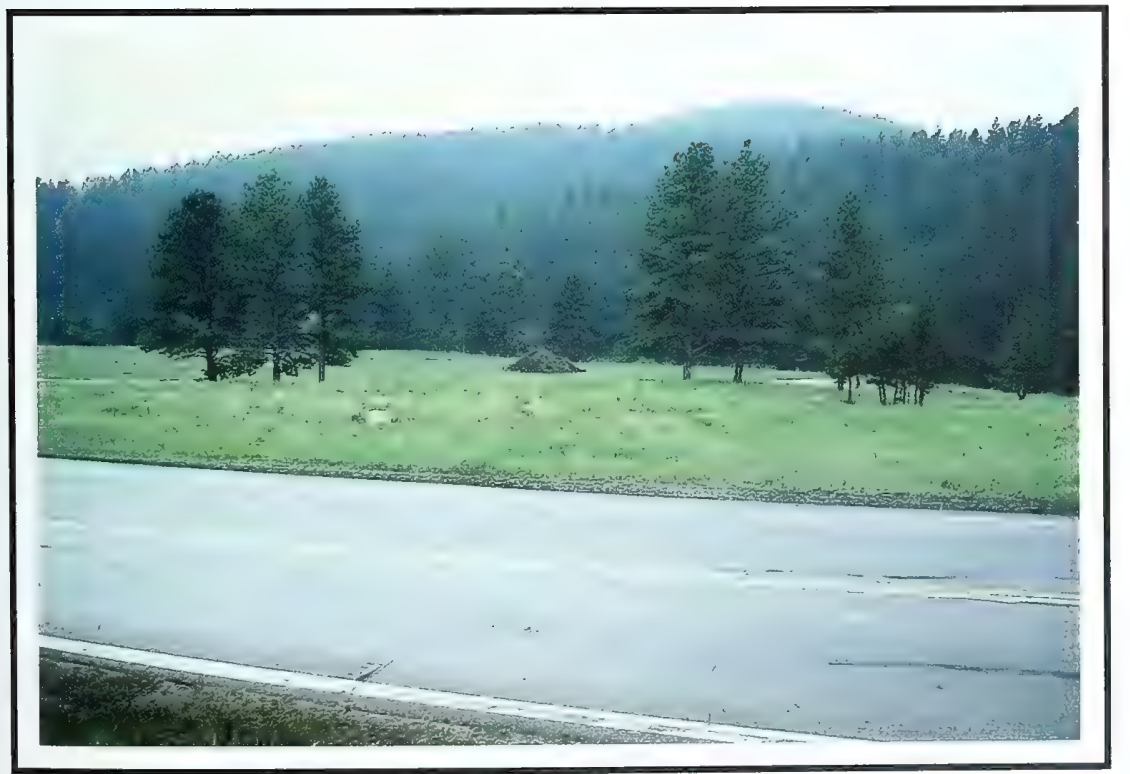




\section{Original Photograph}

July 3, 1927. Shantz

Q-7-1927. Facing south.

\section{First Retake and Description}

June 16, 1958. W.S.P., B-8-1958.

There is remarkably little change in these Dakota Badlands. The same individual plants can be picked out in the old and new photographs with very little change. The hills in the background have Juniperus spp. with Buffalo Berry (from Phillips 1963, p. 113).

\section{Second Retake}

August 3, 1998. Kay-4356-34A.
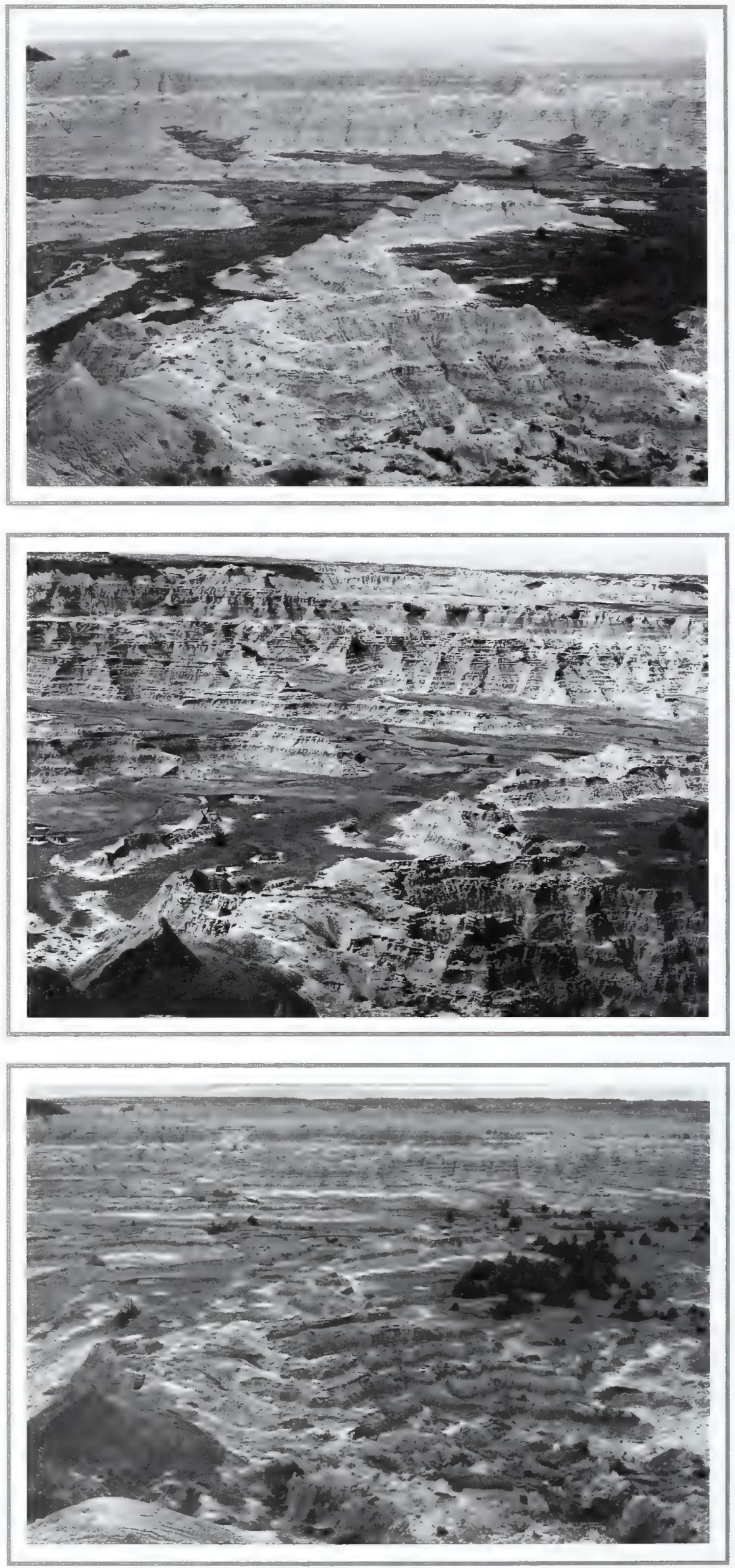


\section{Kadoka, South Dakota}

\section{Location}

Jackson Co., SD; Sec. 30, R. 35 W., T. 43 N.; GPS-UTM 4838058 N, 295232 E.

About 7.5 miles south of Kadoka.

From Kadoka, travel about 7 miles east to intersection of U.S. Interstate 90 and South Dakota Highway 73. Exit right (south) onto South Dakota Highway 73 and travel south about 1 mile to milepost 59. Photopoint is located near milepost 59.

\section{Description}

September 22, 1999

\section{Bottomland}

Grasses. Agropyron smithii, Bouteloua gracilis, Stipa comata, Calamovilfa longifolia

Trees Juniperus spp.

\section{Synopsis}

Minimal change in vegetation composition and structure has occurred. Areas between high clay textured (that is, gumbo) hills is predominately Agropyron smithii, Bouteloua gracilis, Stipa comata, and Calamovilfa longifolia, with a scattering, but increased density, of Juniperus trees. No Shepherdia argentea (buffaloberry) was found.

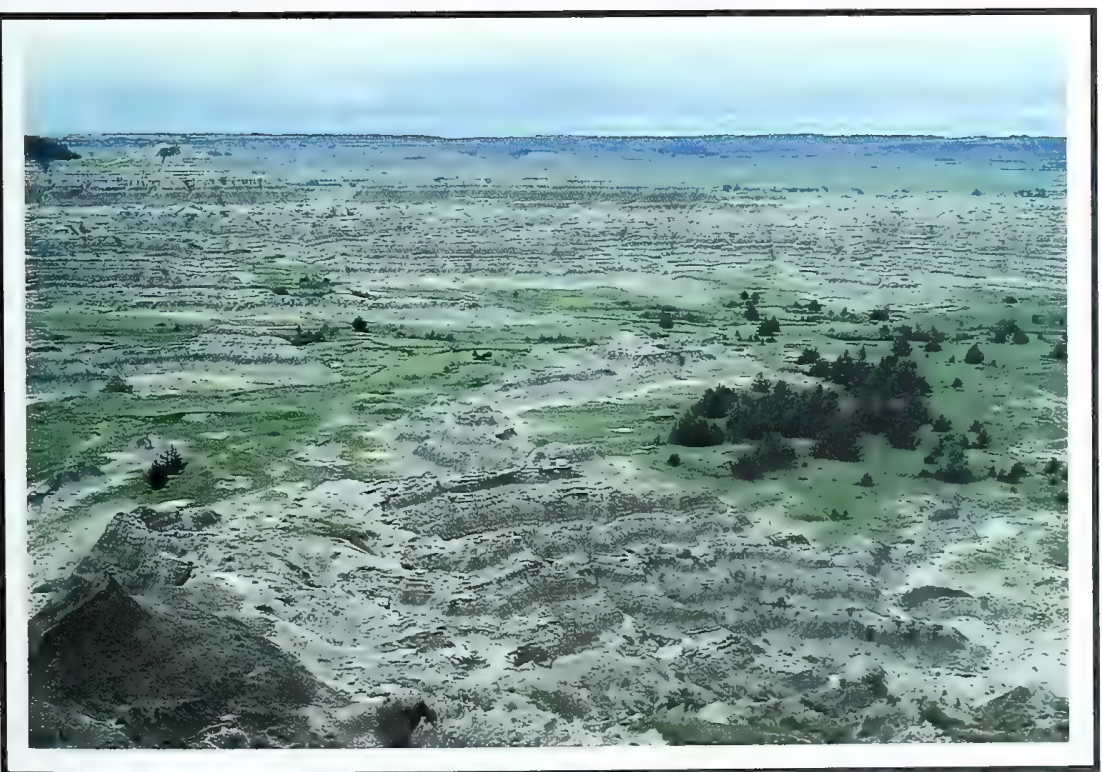




\section{Original Photograph}

June 29, 1913. Shantz

M-2-1913. Facing

northwest.

\section{First Retake and Description}

June 19, 1959. W.S.P.,

No. 2079.

Dr. Shantz took a $180^{\circ}$ panorama from this point and made a rather complete list of the species present at this rock. The main grasses are Agropyron spp. and Stipa viridula. In addition Dr.

Shantz listed the following plants as growing in this area: Agropyron spp., Stipa viridula, Cirsium plattense, Grindelia squarrosa, Phlox spp., Vicia americana, Iva axillaris, Aster spp.,

Lesquerella spp., Erysium asperum, Comandra pallida, Opuntia polycantha, Bahia oppositifolia, Helianthus spp., Atriplex canescens, Allium reticulatum, and Plantago purshii. In the pictures of this area the most noticeable changes between the old and the new is the increase in the amount of Prickly Pear in the new pictures (from Phillips 1963, p. 119).
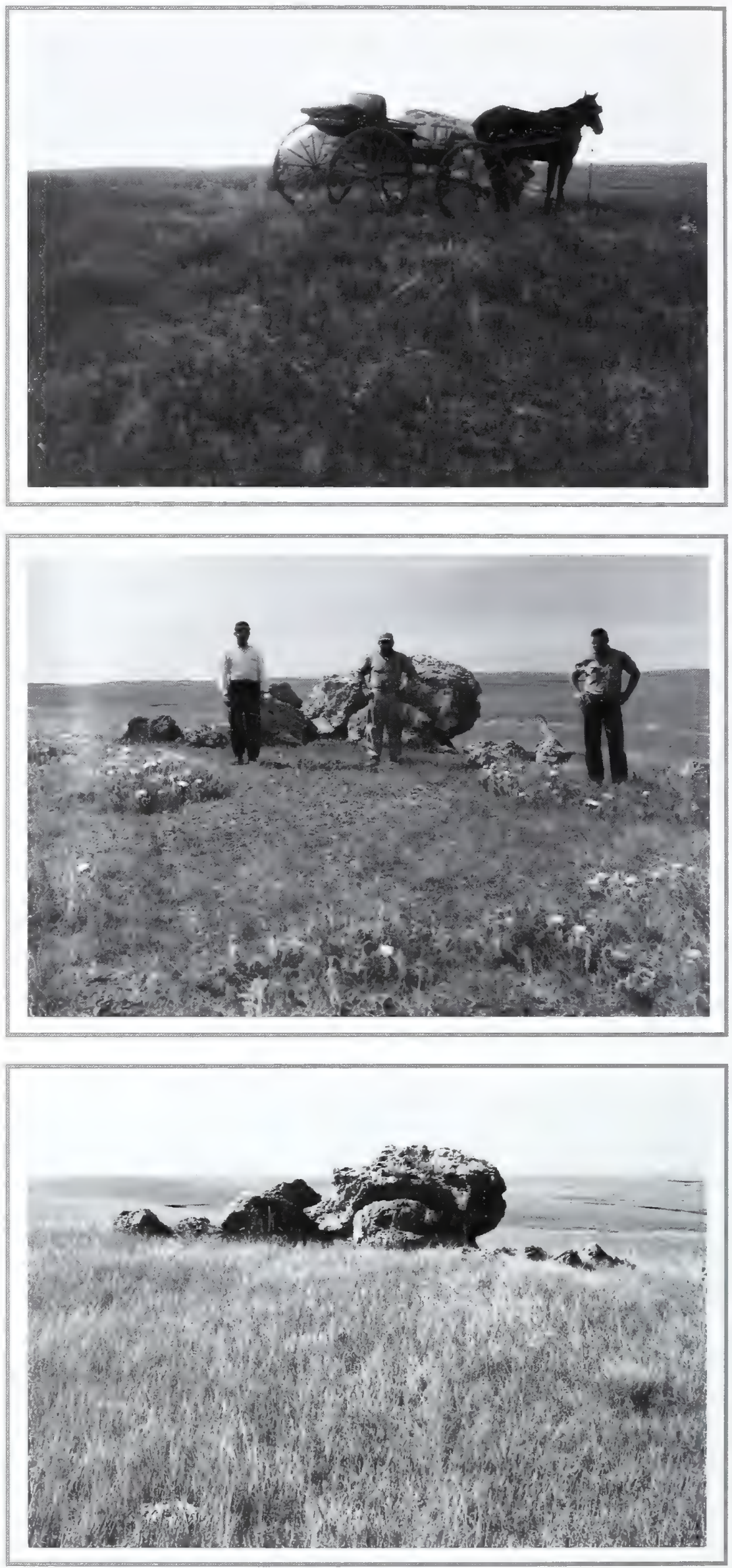


\section{Newell, South Dakota}

\section{Location}

Butte Co., SD; Sec. 4, R. 6 E., T. 9 N.; GPS-UTM 4959195 N, 626870 E.

About 6 miles north-northeast of Newell.

From Newell, travel north about 4 miles on South Dakota Highway 79. Next, turn right (east) for 1 mile across private lands, then turn left (northeast) through a gate onto a tertiary road and continue for 1 mile. Continue north about 0.7 mile through two pastures to a group of large rocks located in the south-central part of the second pasture. Photopoint is north of the adjacent irrigation canal and hayfield and west of a natural drainage area.

\section{Description}

September 22, 1999

\section{Upland}

Grasses. Agropyron smithii, Stipa comata, Stipa viridula, Bromus japonicus
Forbs. Melilotus officinalis, Lesquella spp., Psoralea tenuiflora, Grindelia squarrosa, Vicia americana

\section{Synopsis}

Earlier photos indicate heavy grazing. However, 1998 photos reveal grazing intensity had been dramatically reduced, resulting in a grass-dominant complex of Agropyron smithii, Stipa comata, and Stipa viridula. Furthermore, the position of the large rocks has remained constant, but an abundance of Melilotus officinalis in 1999 caused their presence to be less conspicuous because of the taller vegetation.

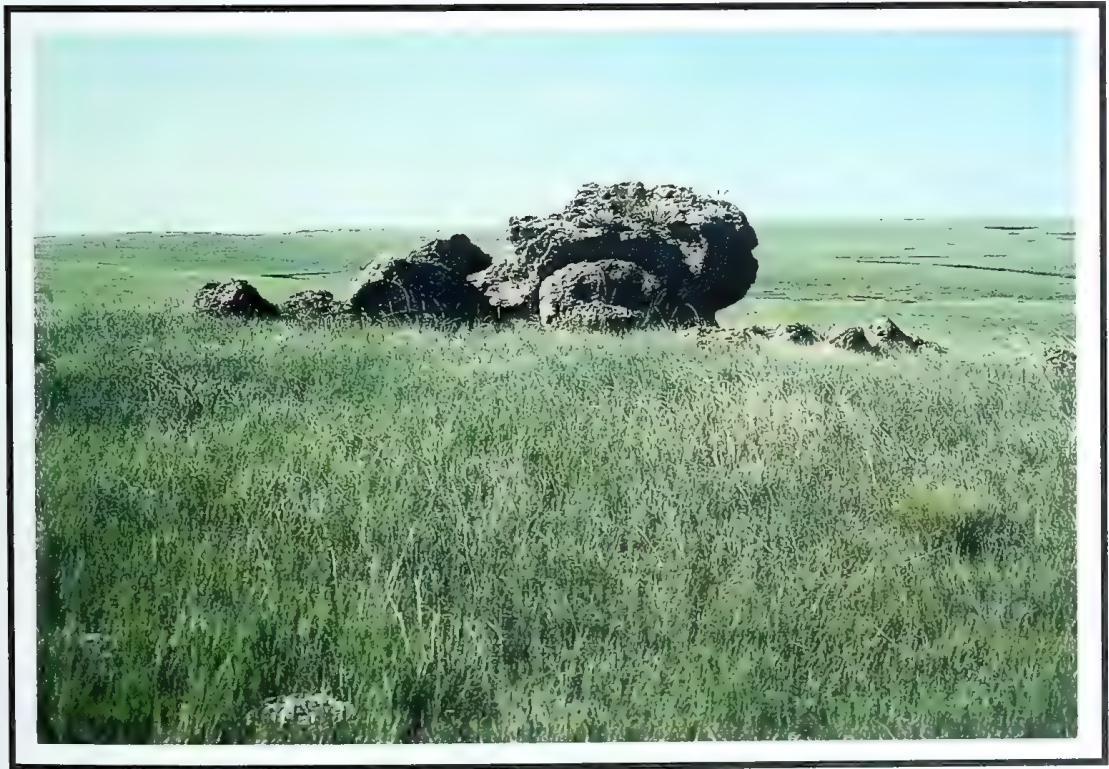




\section{Original Photograph}

June 29, 1913. Shantz

M-4-1913. Facing north.

\section{First Retake and}

\section{Description}

June 19, 1959. W.S.P., B-5-1959.

This is one of the series of panoramic pictures Dr. Shantz took from this point. The alkali areas showing in the original photograph are almost entirely gone. Grasses (Agropyron spp. and Stipa viridula) seem to be about the same (from Phillips 1963, p. 121).
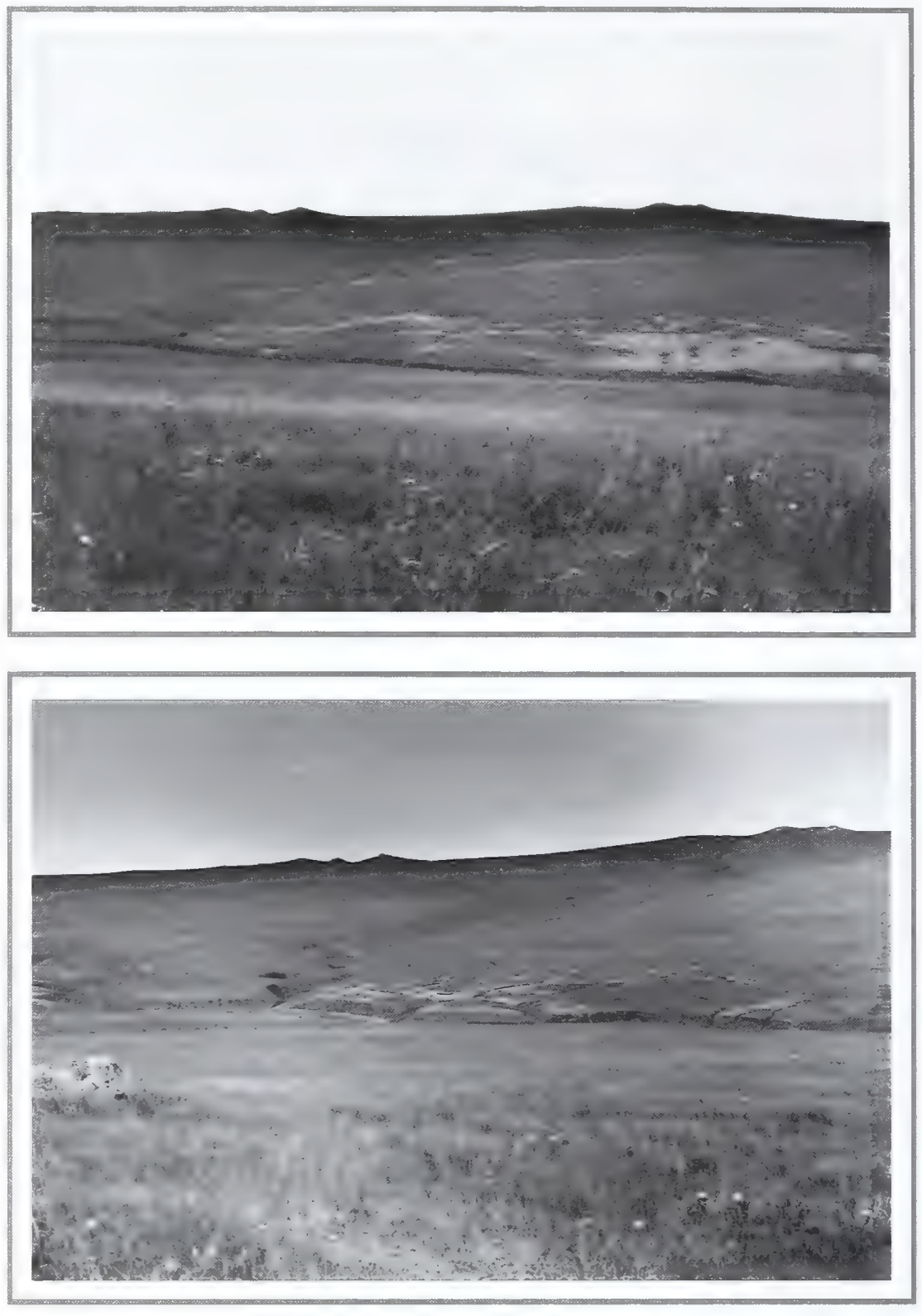

Second Retake

July 31, 1998.

Kay-4351-25A.

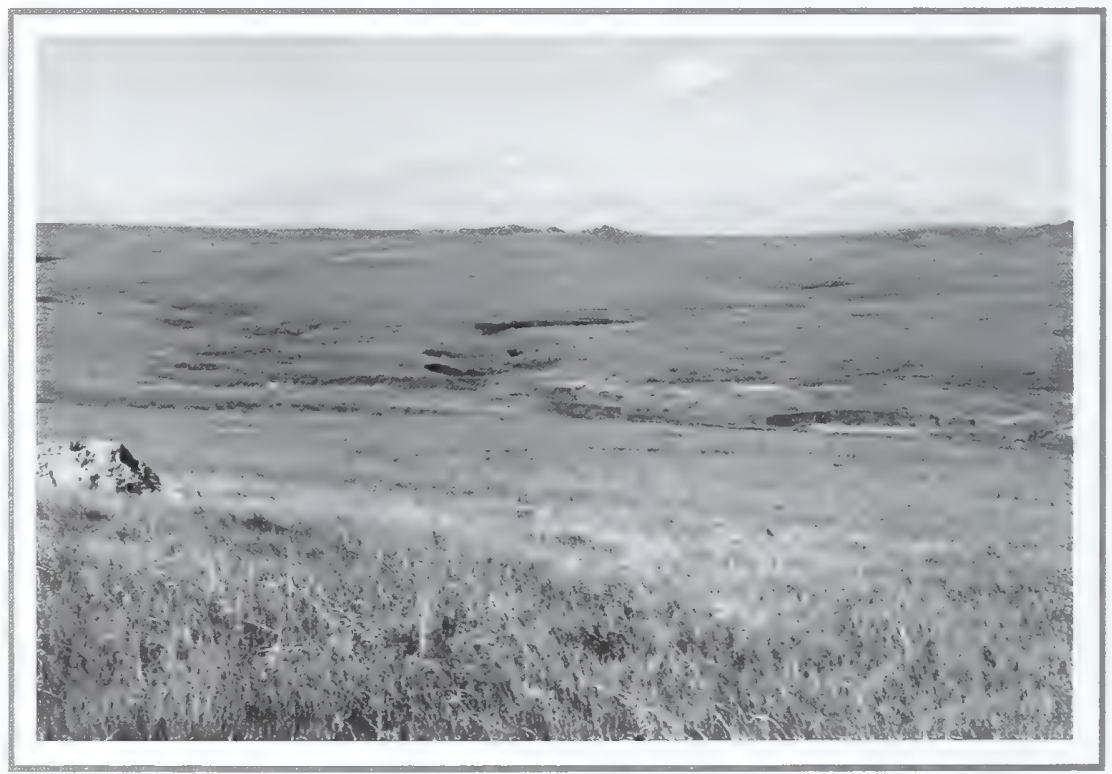




\section{Newell, South Dakota}

\section{Location}

Butte Co., SD; Sec. 4, R. 6 E., T. 9 N.; GPS-UTM 4959195 N, 626870 E.

About 6 miles north-northeast of Newell.

From Newell, travel north about 4 miles on South Dakota Highway 79. Next, turn right (east) for 1 mile across private lands, then turn left (northeast) through a gate onto a tertiary road and continue for 1 mile. Continue north about 0.7 mile through two pastures to a group of large rocks located in the south-central part of the second pasture. Photopoint is north of the adjacent irrigation canal and hayfield and west of a natural drainage area.

\section{Description}

September 22, 1999

\section{Upland}

Grasses. Agropyron smithii, Stipa comata, Stipa viridula, Bromus japonicus

Forbs. Melilotus officinalis, Lesquella spp., Psoralea tenuiflora, Grindelia squarrosa, Vicia americana

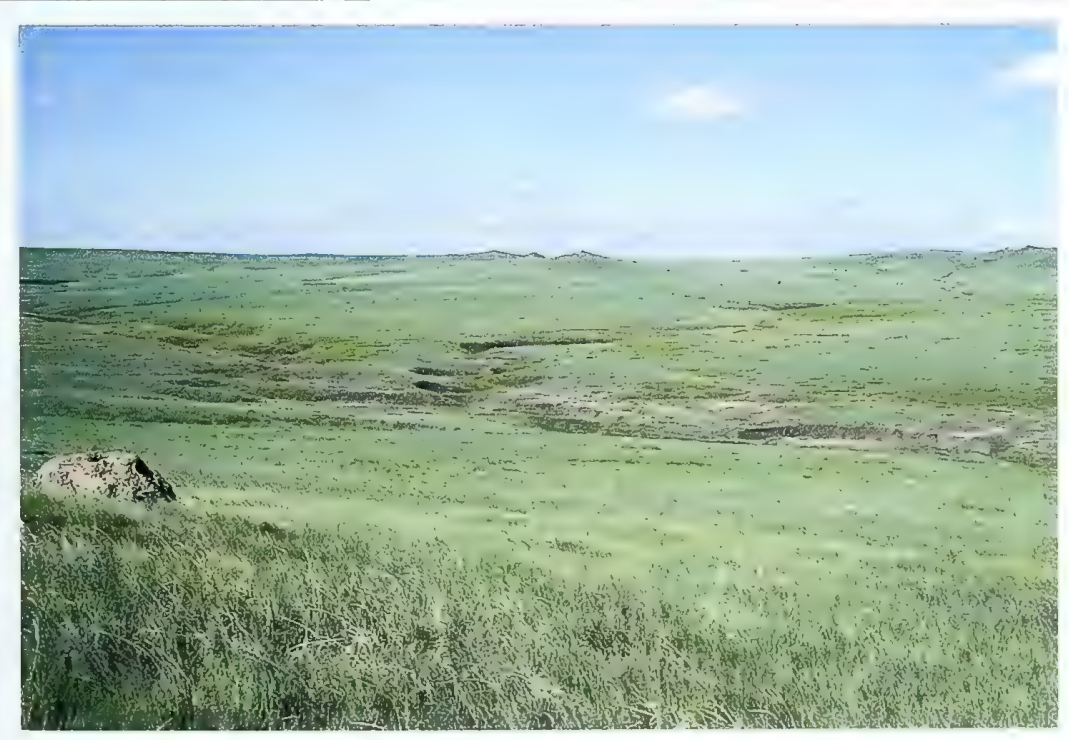

\section{Synopsis}

The vegetation has remained a grass-dominated mix of Agropyron smithii, Stipa comata, and Stipa viridula. Forbs are abundant, with considerable amounts of Melilotus officinale found in 1999, but not apparent in the photos shown here. The abundance of Opuntia polycantha has declined sharply in at least a partial response to occasional haying of the area (communication with landowner). The soils/vegetation complex throughout the area appears to have recovered fully from previous management tactics. 


\section{Original Photograph} July 6, 1927. Shantz V-3-1927. Facing east.

\section{First Retake and Description}

August 11, 1960. W.S.P., E-8-1960.

Dr. Shantz' original picture shows an almost pure stand of Agropyron smithii. When the 1960 picture was taken there was very little of this grass, there being mainly Koeleria cristata (from Phillips 1963, p. 129).
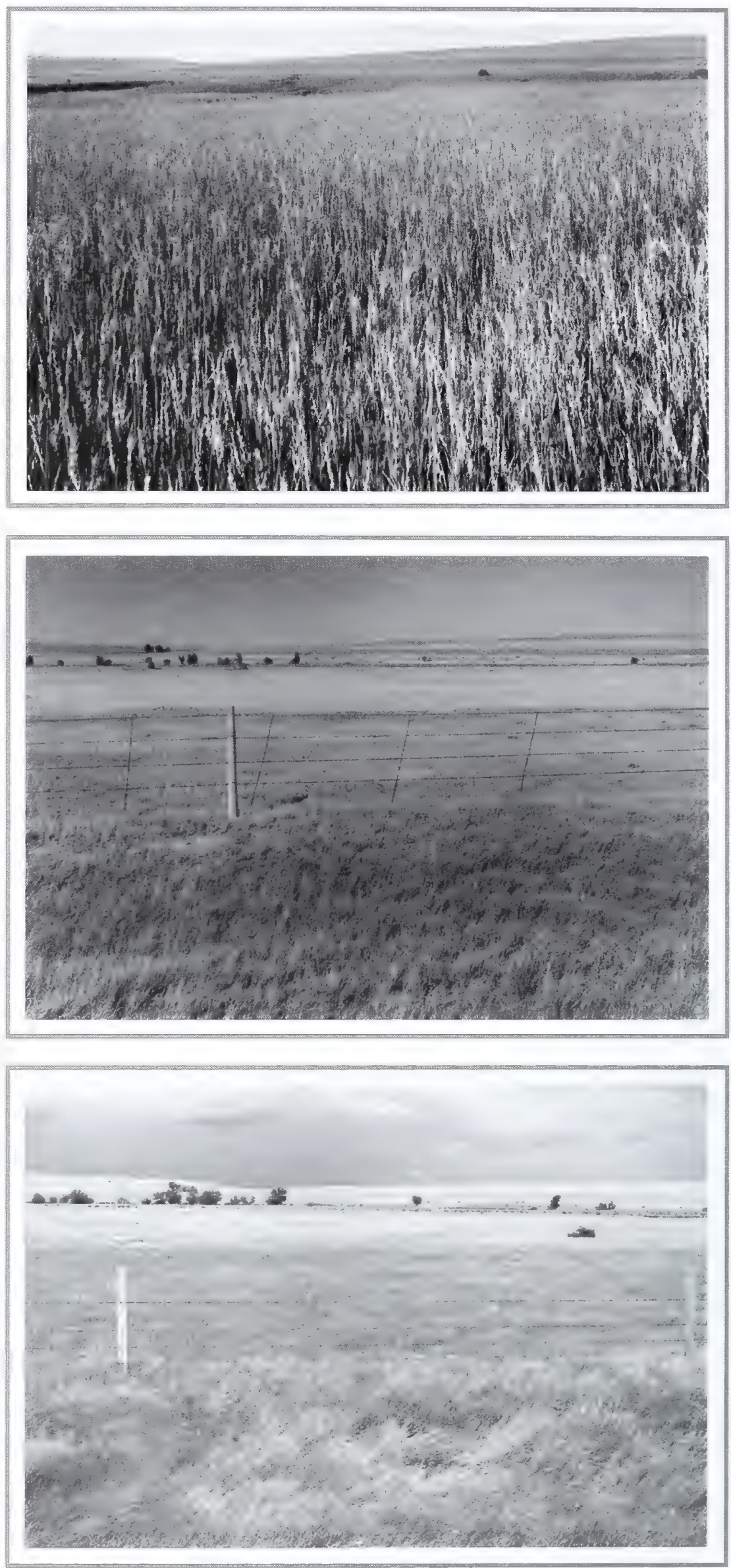


\section{Rumford, South Dakota}

\section{Location}

Fall River Co., SD; Sec. 6, R. 54 W., T. 36 N. GPS-UTM 4775673 N, 606085 E.

About 8 miles north-northwest of Ardmore.

From Ardmore, South Dakota, travel north about 6 miles on South Dakota Highway 71, then turn left (northwest) for 2 miles on South Dakota Highway 471 (County Road 52). Photopoint is from road near a gravel parking area that replaced a railroad switching yard.

\section{Description}

September 21, 1999

\section{Between Fence and Road}

Grasses. Agropyron

cristatum, Setaria spp.,

Bromus inermis

Forbs. Helianthus annuus

\section{Fence to Drainage}

Grasses. Agropyron

cristatum, Agropyron smithii

Shrubs. Sarcobatus

vermiculatus

Trees. Populus deltoides

\section{Synopsis}

Current herbaceous vegetation is dominated by Agropyron cristatum. This is a shift from a dominance of Agropyron smithii in 1927 (seeded?) and possibly Koeleria pyramidata in 1960 , although close examination of the 1960 photo suggests the dominant species was still Agropyron smithii. Both the size and density of Populus deltoides trees growing along the drainage have increased considerably since 1927. 


\section{Original Photograph}

August 10, 1914. Shantz R-8-1914. Facing northwest.

\section{First Retake and Description}

June 20, 1959. W.S.P., C-3-1959.

This is a series of three panoramic pictures taken at this point. The original description shows the following species present: Stipa comata, Artemisia frigida, Gutierrezia sarothrae, Paronychia jamesii, Carex filifolia, Artemisia canadensis, Chrysopsis villosa, and Artemisia gnaphalodes (from Phillips 1963, p. 131).

Second Retake

July 31, 1998.

Kay-4349-28.
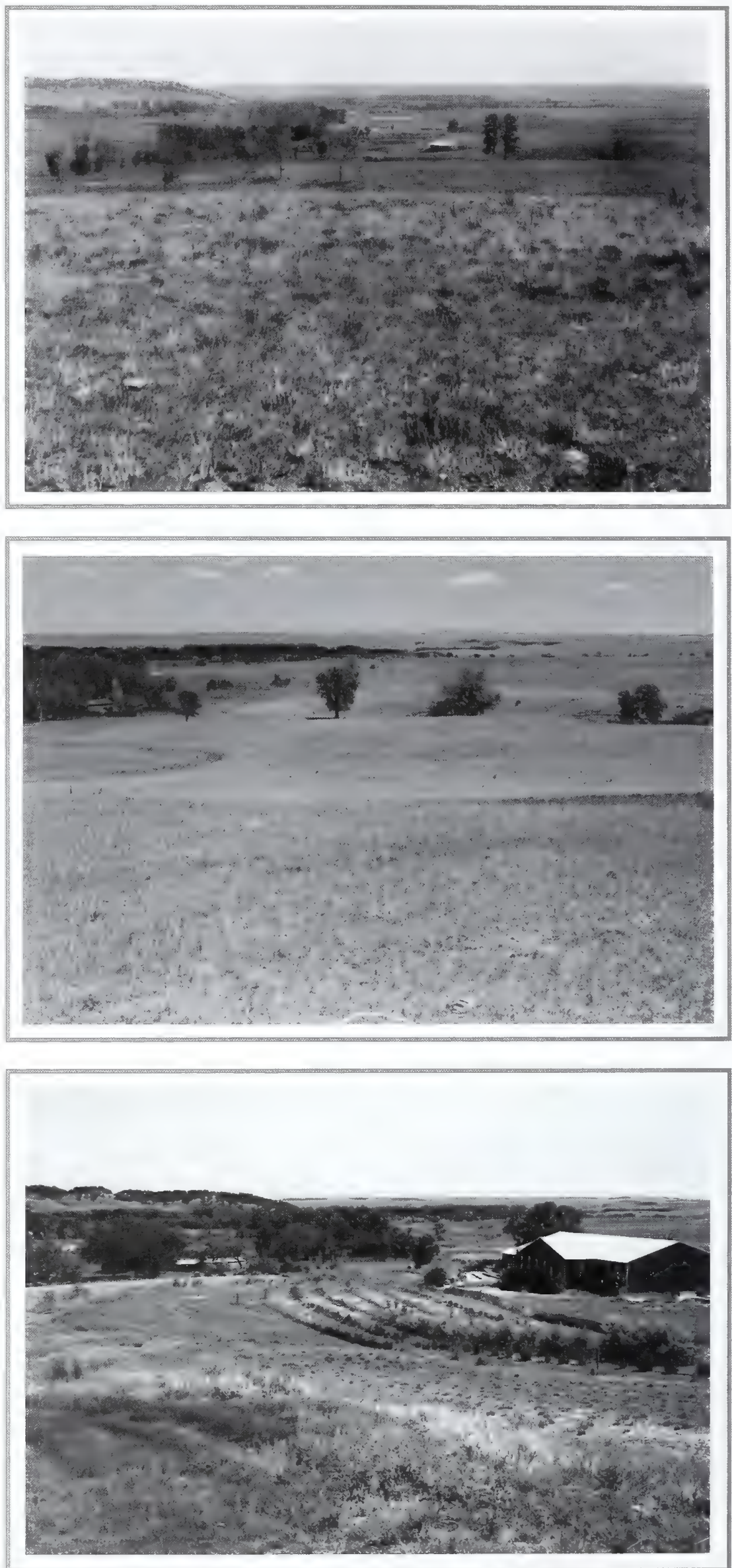


\section{Spearfish, South Dakota}

\section{Location}

Lawrence Co., SD; Sec. 10, R. 2 E., T. 7 N.; GPS-UTM 4936725 N, 590582 E.

About 6.4 miles north of Spearfish.

From Spearfish, travel north 6.4 miles on U.S. Highway 85. Turn right (east) onto a private lane. The photopoint is from the small hill, to the left (north), immediately upon entering the private property.

\section{Description}

September 21, 1999

\section{Photopoint}

Grasses. Agropyron intermedium, Agropyron smithii, Agropyron cristatum, Poa secunda, Schizachyrium scoparium, Bromus inermis

Forbs. Melilotus officinalis, Grindelia squarrosa, Aster spp.

Shrubs. Gutierrezia sarothrae

\section{Creek Bottom and Drainages}

Shrubs and Trees. Artemisia frigida, Artemisia dracunculoides, Artemisia cana, Populus deltoides, Eleagnus angustifolia, Fraxinus pennsylvanica, Shepherdia argentea

\section{Synopsis}

Many species are growing on this site, most of which are invaders or seral species. Foreground is a seeded remnant gravel site. The vegetation near the photopoint has been mowed recently. Dominant species are Agropyron intermedium, Agropyron smithii, Agropyron cristatum, Grindelia squarrosa, Melilotus officinalis, Aster spp., Poa secunda, Schizachyrium scoparium, Artemisia frigida, Artemisia cana, and Artemisia dracunculoides. Background is now dominated by cropland and farm building. The most notable vegetation change on the drainages is the increase in size and abundance of Populus deltoides, Eleagnus angustifolia, Prunus virginiana, and Fraxinus pennsylvanica. Pinus ponderosa density has increased on the hill in the upper left of the 1998 photo. Cropland is planted to Medicago sativa. 


\section{Original Photograph}

August 10, 1914. Shantz R-12-1914. Facing west.

\section{First Retake and Description}

June 20, 1959. W.S.P., B-9-1959. No photo available.

The river valley is showing an increase in tree numbers. One tree of Box Elder is filling in the erosion gully in almost the exact center of the photograph. The background of the picture shows good grass because of restricted grazing (from Phillips 1963, p. 133).

Second Retake

July 31, 1998. Kay-4349-36.

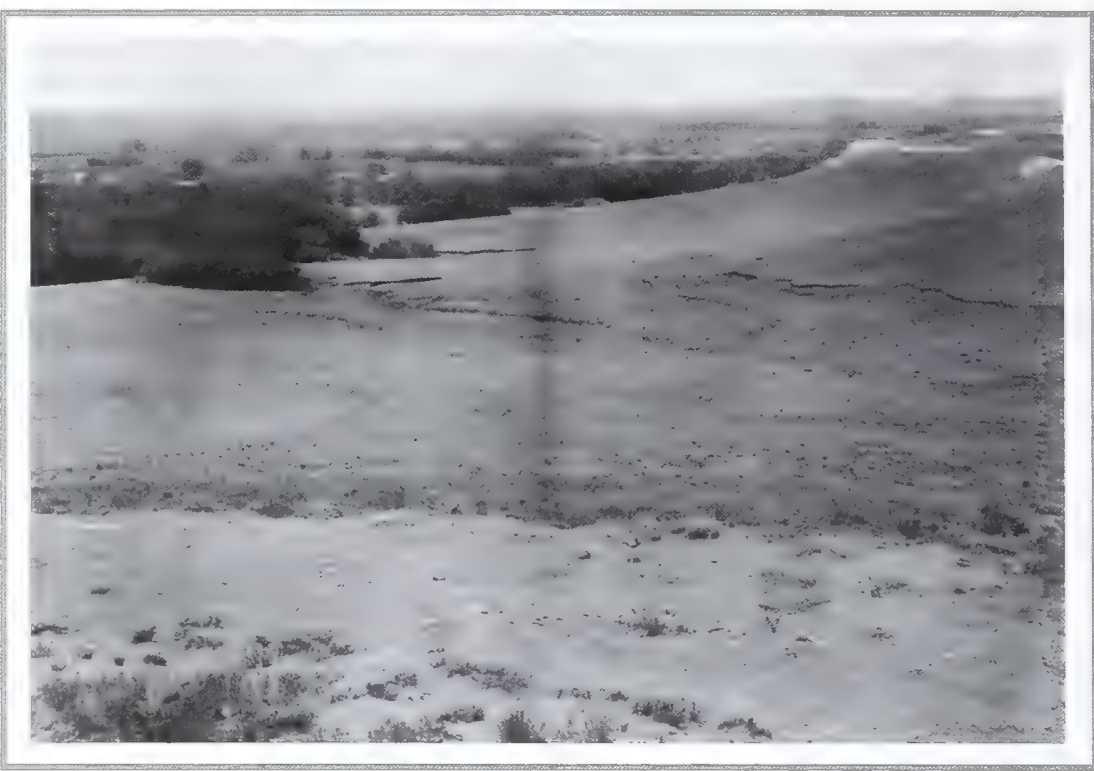

NO PHOTO AVAILABLE

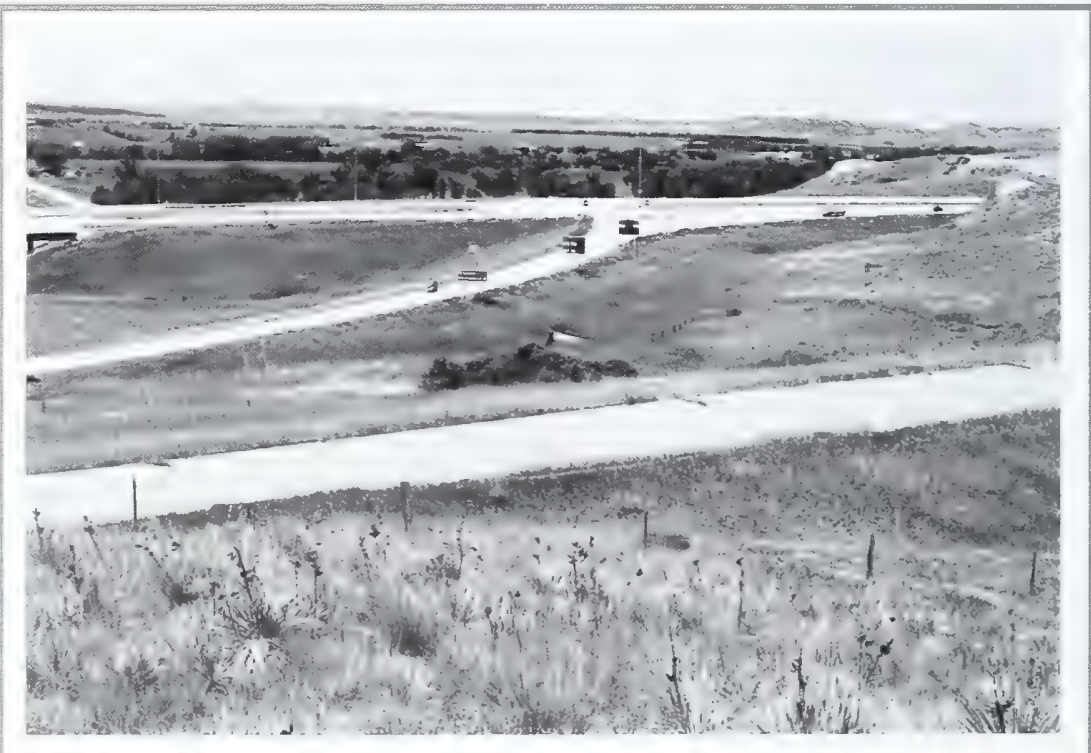




\section{Spearfish, South Dakota}

\section{Location}

Lawrence Co., SD; Sec. 34, R. 2 E., T. 7 N.; GPS-UTM 4930102 N, 590496 E.

About 2 miles north of Spearfish.

From Spearfish, travel north about 2 miles to the junction of U.S. Highways 14 and 85. Turn right (east) onto access road parallel to U.S. Highway 85, next to public utility station. Then, travel south about 0.5 mile. Picture was taken on the hill to the left (east) of access road.

\section{Description}

September 21, 1999

\section{Before Fence}

Grasses. Agropyron smithii, Stipa comata, Schizachyrium scoparium, Muhlenbergia cuspidata, Carex filifolia, Calamovilfa longifolia, Panicum virgatum

Shrubs and Trees. Rosa woodsii, Artemisia frigida, Yucca glauca, Gutierrezia sarothrae

\section{Along Roadside}

Grasses. Bromus inermis, Agropyron intermedium, Panicum virgatum

Trees. Populus deltoides, Fraxinus pennsylvanica

\section{Synopsis}

Although this set of photos shows highway and urban development, the geological features of rock outcrops are still apparent at the right center of photos. The distant hills show an increase in conifer density, while deciduous tree species have remained about the same as they were in 1914 due to land management practices. Note the abundance of Yucca glauca in the vegetation complex in foreground.

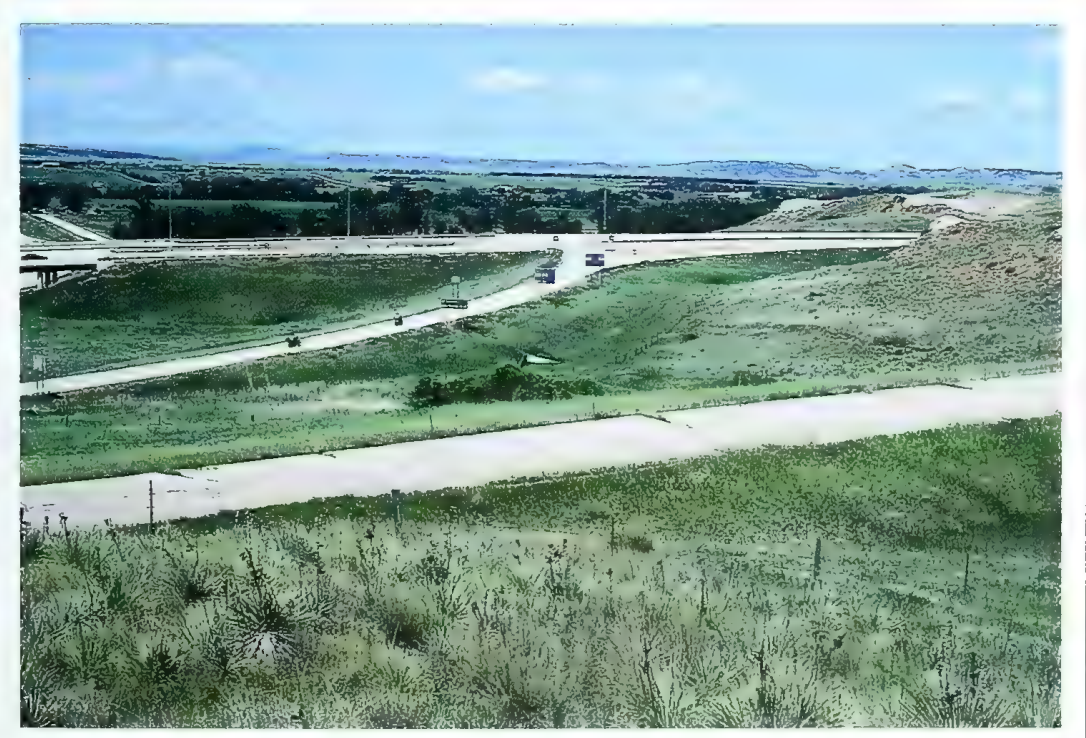




\section{Original Photograph}

August 10, 1914.

Shantz S-4-1914.

Facing southeast.

\section{First Retake and Description}

June 22, 1958. W.S.P., F-6-1958.

This is a hill to the southeast of the picture point and it has good recovery of grass with the same Rhus spp. in the foreground. The old road ran along by the power lines and is still visible. In the background the hill has shown but little removal of the tree species (from Phillips 1963, p. 135).

\section{Second Retake}

July 31, 1998.

Kay-4351-19A.
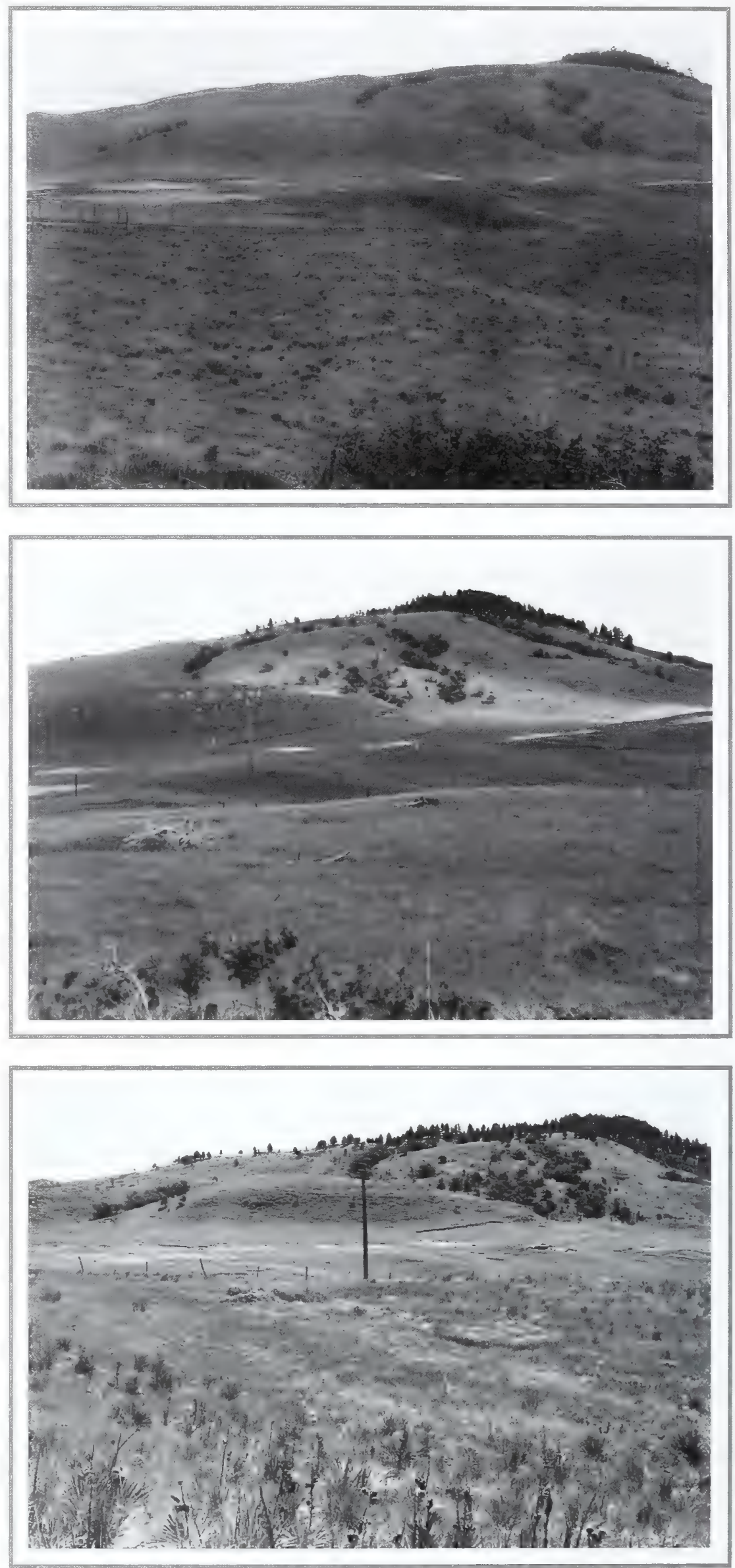


\section{Spearfish, South Dakota}

\section{Location}

Lawrence Co., SD; Sec. 34, R. 2 E., T. 7 N.; GPS-UTM 4930102 N, 590496 E.

About 2 miles north of Spearfish.

From Spearfish, travel north about 2 miles to the junction of U.S. Highways 14 and 85. Turn right (east) onto access road parallel to U.S. Highway 85, next to public utility station. Then, travel south about 0.5 mile. Picture was taken on the hill to the left (east) of access road.

\section{Description}

September 21, 1999

\section{Upland to Hills}

Grasses. Agropyron smithii, Stipa comata, Schizachyrium scoparium, Muhlenbergia cuspidata, Carex filifolia, Calamovilfa longifolia, Panicum virgatum

Shrubs and Trees. Artemisia frigida, Yucca glauca, Gutierrezia sarothrae

\section{Hills and Foothills}

Grasses. Agropyron smithii, Carex filifolia, Stipa comata, Calamovilfa longifolia, Panicum virgatum

Shrubs and Trees. Pinus ponderosa, Quercus macrocarpa

\section{Synopsis}

An electric line and fence have been in existence since 1914 . Pinus ponderosa and Quercus macrocarpa have increased on the distant hillside over the years. In the foreground, Yucca glauca seems to have increased dramatically, and grass production and cover have improved.

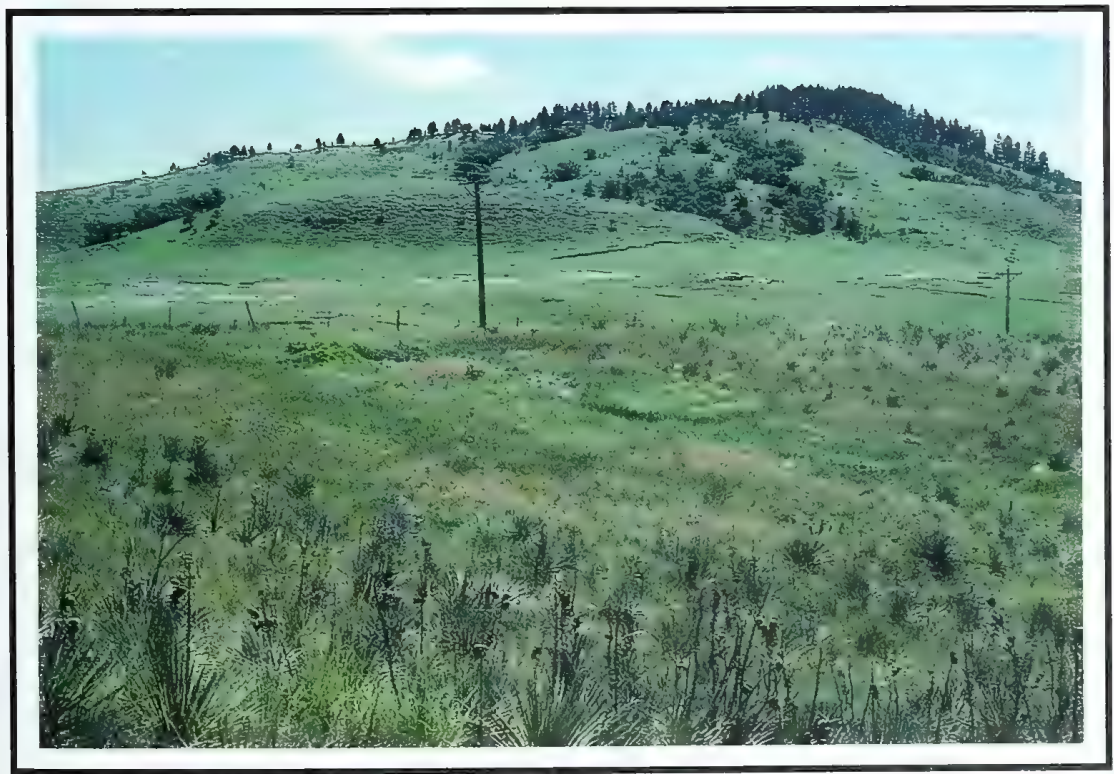




\section{Original Photograph}

July 2, 1927. Shantz N-21927. Facing northwest.

\section{First Retake and Description}

June 16, 1958. W.S.P., C-8-1958.

The original picture shows much Andropogon scoparius. There seems to be very little of this grass left in the retake, but Stipa viridula and Bouteloua gracilis are very common. The trees along the river are Cottonwood and Willow (from Phillips 1963, p. 143).
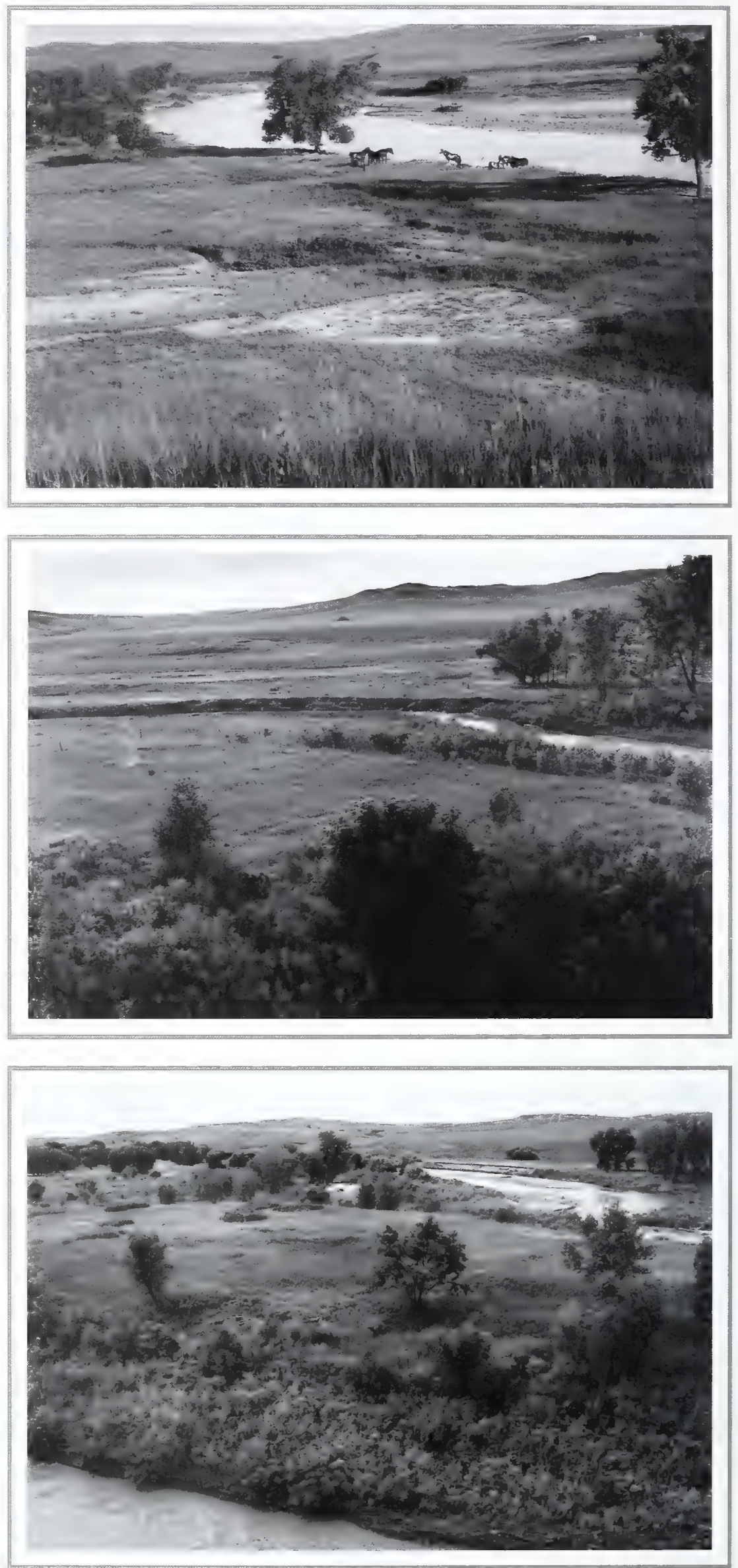


\section{White River, South Dakota}

\section{Location}

Mellette Co., SD; Sec. 19, R. 28 W., T. 42 N.; GPS-UTM 4829632 N, 362066 E.

About 3.5 miles northeast of White River.

From the junction of U.S. Highways 44 and 83 in White River, South Dakota, travel north 2.2 miles on U.S. Highway 83. Then, turn right (east) onto an unnamed gravel road just south of the Little White River bridge. Continue east for 2.3 miles to an unfenced area adjacent to the White River. From this point, the photopoint is north of the road about 50 yards.

\section{Description}

September 22, 1999

\section{Island on White River}

Grasses. Stipa viridula, Stipa comata, Bouteloua curtipendula, Bouteloua gracilis, Agropyron smithii, Spartina pectinata, Elymus canadensis, Andropogon gerardii, Andropogon hallii, Schizachyrium scoparium, Calamovilfa longifolia
Forbs. Solidago spp.,

Xanthium strumarium, Artemisia ludoviciana, Conyza canadensis, Ambrosia psilostachya, Ambrosia gigantea

Shrubs. Amorpha canescens, Prunus spp., Rhus trilobata, Symphoricarpos occidentalis, Fraxinus pennsylvanica. Acer negundo, Salix spp., Populus deltoides, Shepherdia argentea

\section{Riverbanks}

Trees. Populus deltoides, Fraxinus pennsylvanica

\section{Synopsis}

The largest portion of land area shown in the photograph is now an island because of a change in the river's course. Grazing intensity appears to have been extremely heavy in the 1927 photo (see horses) but much reduced thereafter. Accordingly, density of both herbaceous and woody species have increased along riverbanks, with Populus deltoides the dominant tree. Fields across the river are now planted to Medicago sativa and Bromus inermis.

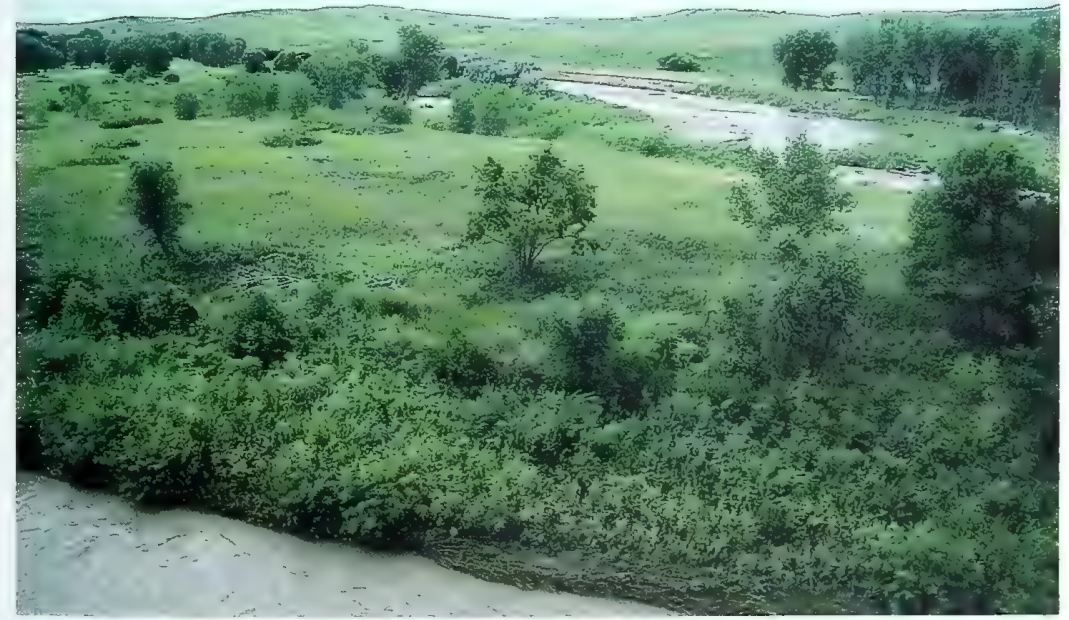




\section{Original Photograph}

September 27, 1917.

Shantz S-10-1917.

Facing southeast.

\section{First Retake and Description}

July 5, 1959. W.S.P., I-10-1959.

The original picture shows a very much overgrazed range. The grasses consisting of depauperate Bouteloua plants, Carex filifolia, and some Phlox spp. The retake shows an improved range with a fair amount of Bouteloua gracilis. However, Carex filifolia is still abundant and there is some Stipa spp. still present (from Phillips 1963, p. 151).
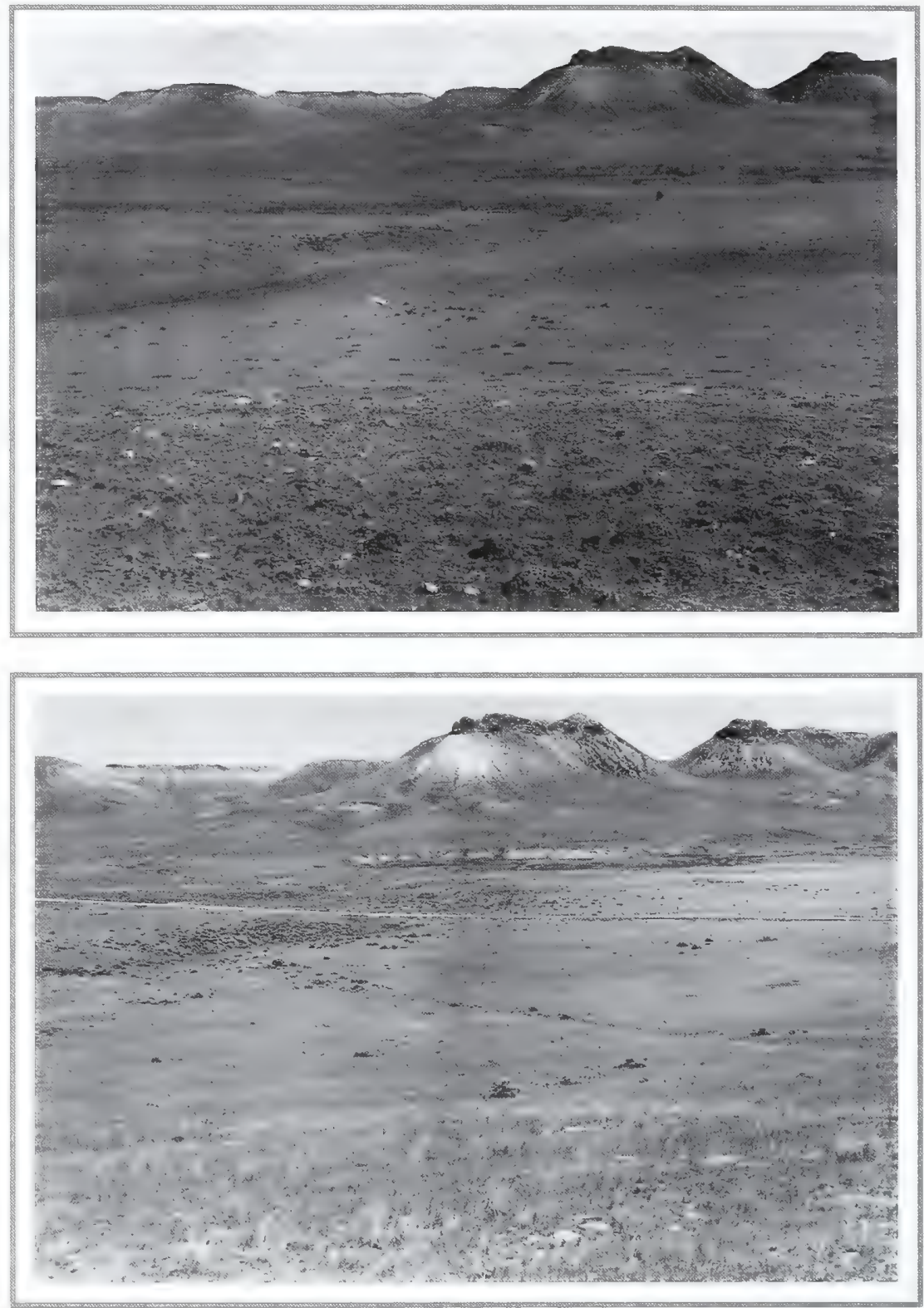

\section{Second Retake}

July 27, 1998.

Kay-4344-34.

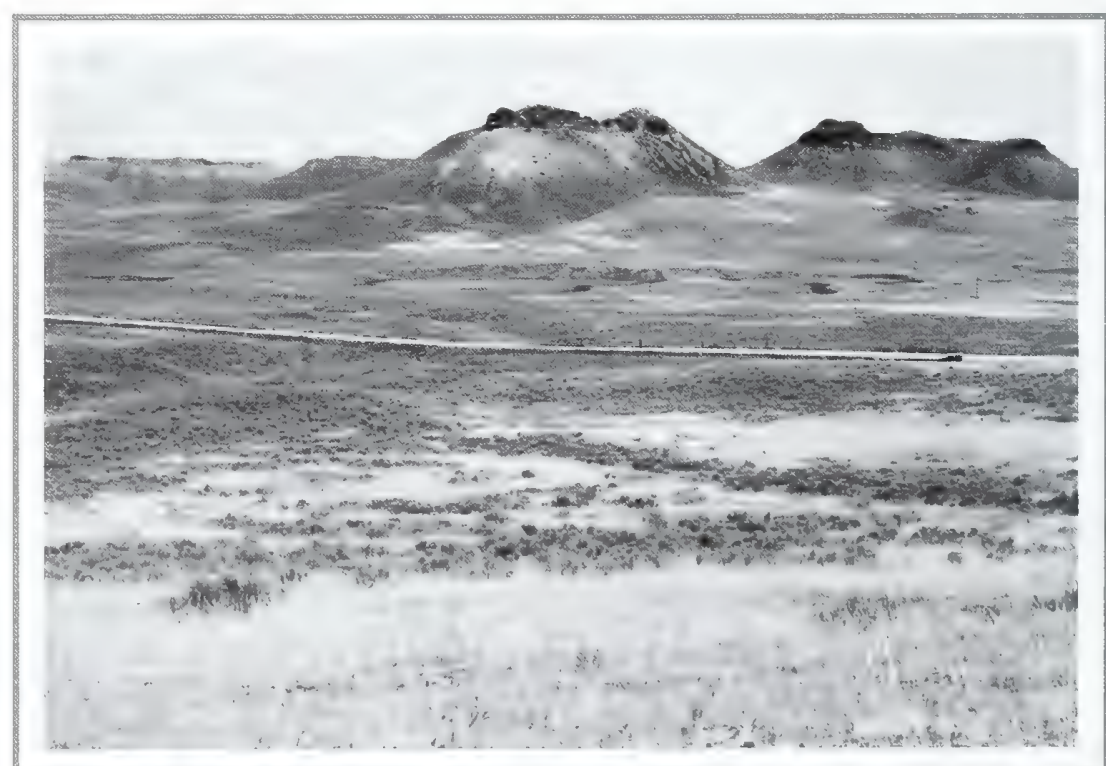




\section{Buffalo, Wyoming}

\section{Location}

Johnson Co., WY; Sec. 12, R. 81 W., T. 50 N.; GPS-UTM 4908859 N, 376974 E.

Upon exiting U.S. Interstate 25 at Buffalo, travel east on the main road before turning right onto county road TW. Continue southeast 8.4 miles to Tipperary Road before turning left (northeast) onto a secondary road. Continue northeast for 0.5 mile and stop near drainage that is present on both sides of the road. Photopoint is located on a hill about 250 yards left (northwest).

\section{Description}

September 8, 1999

\section{Upland to Road}

Grasses. Bouteloua gracilis, Buchloe dactyloides, Carex filifolia, Koeleria pyramidata, Agropyron smithii, Stipa comata, Agropyron spicatum, Stipa viridula, Bromus japonicus, Bromus tectorum

Shrubs. Artemisia tridentata, Artemisia frigida

\section{South of Highway to Hills}

Grasses. Buchloe

dactyloides, Stipa comata,

Poa secunda, Koeleria pyramidata, Carex filifolia, Agropyron smithii, Bromus japonicus, Agropyron cristatum, Stipa viridula

Shrubs. Artemisia tridentata, Artemisia frigida

\section{Synopsis}

The 1917 photo shows a highuse area as noted by the state of vegetation. By 1959, the vegetation had recovered moderately and Artemisia tridentata had increased. The 1998 photo shows a more productive site, with good grass cover and a tremendous increase in Artemisia tridentata.

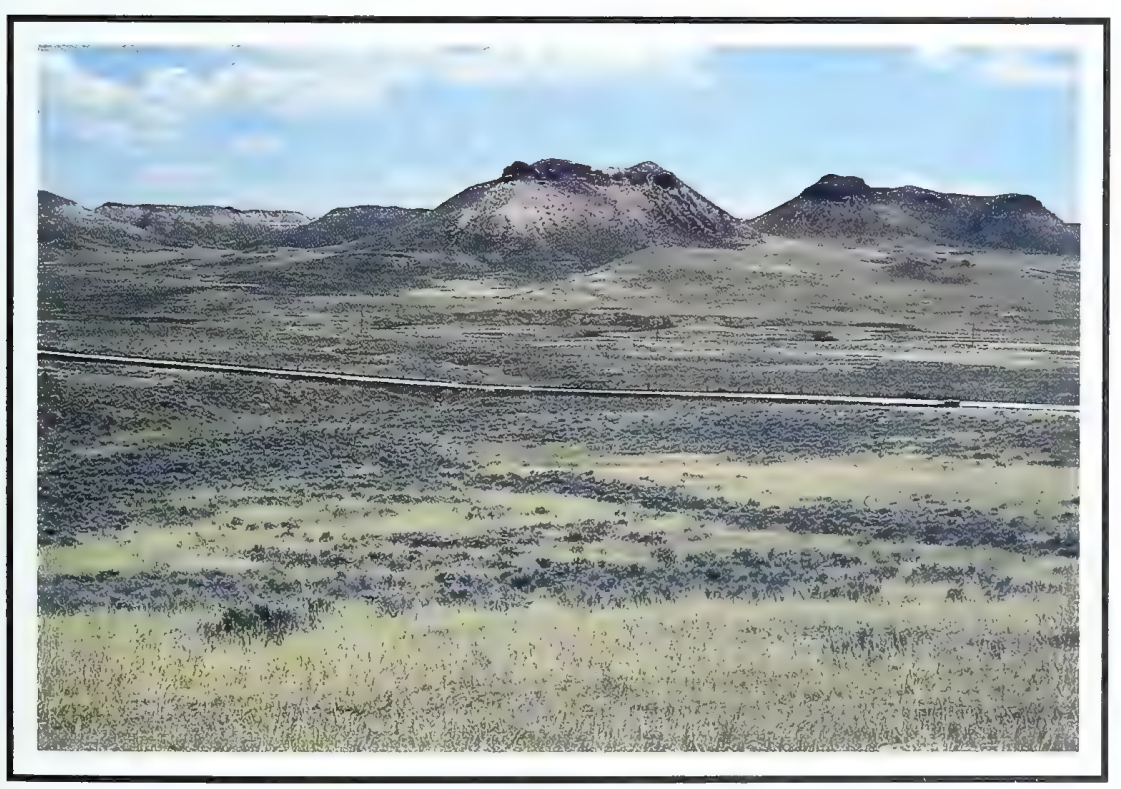




\section{Original Photograph}

August 20, 1916. Shantz M-11-1916. Facing north-northwest.

First Retake and

\section{Description}

July 7, 1959. W.S.P., J-4-1959.

The original picture shows Koeleria cristata and Carex filifolia as the main plants. The same plants are present in the retake, although Stipa spp. is very abundant (from Phillips 1963,

p. 155).

Second Retake

August 4, 1998.

Kay-4360-18.
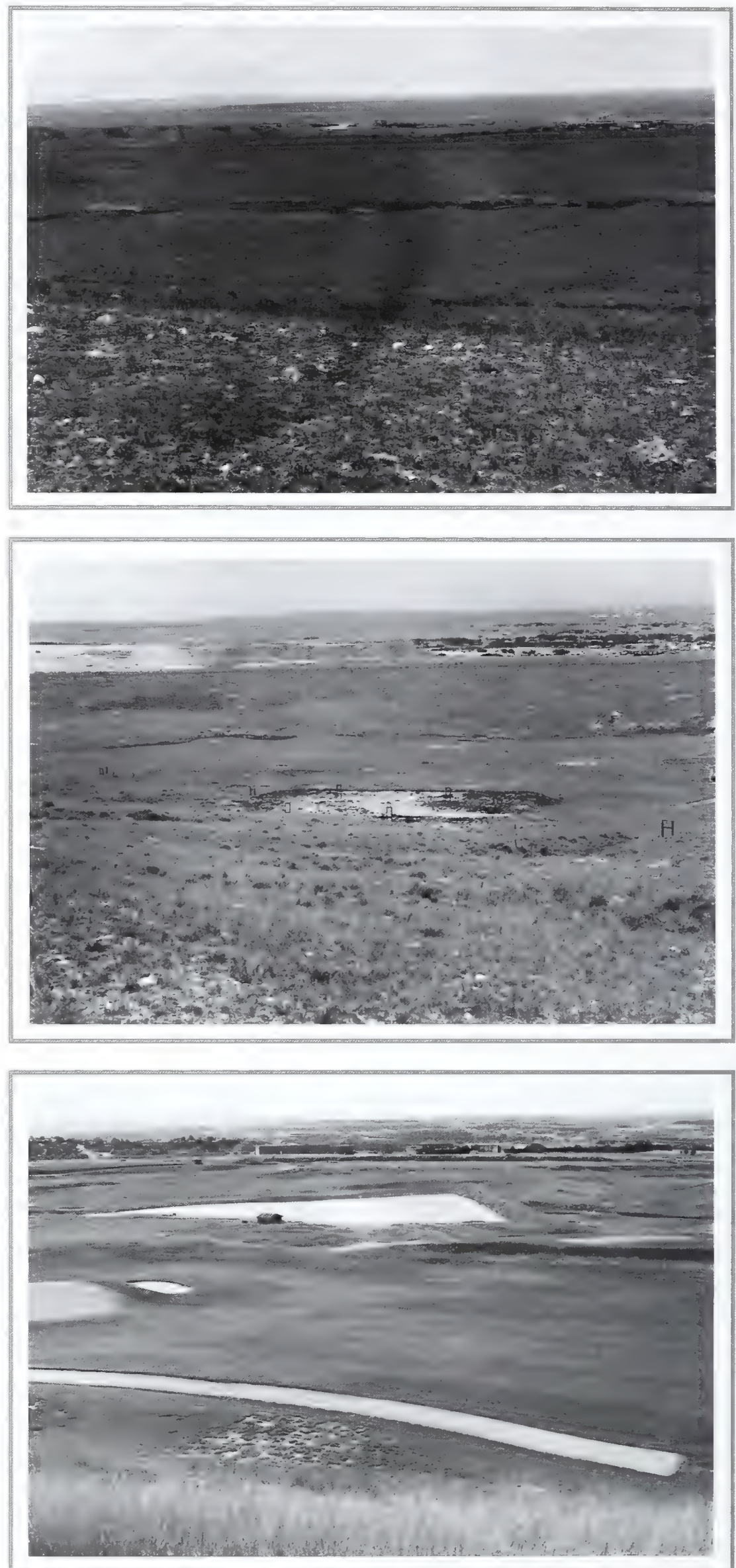


\section{Casper, Wyoming}

\section{Location}

Johnson Co., WY; Sec. 16, R. 79 W., T. 33 N.; GPS-UTM 4741931 N, 392000 E.

About 4 miles southeast of Casper.

Exit U.S. Interstate 25, 2 miles south of Casper onto Wyoming Highway 258 (south loop of Casper). Continue on south loop and turn left (south) onto Walcott Street. Then turn left (east) onto 15th Street, then right (south) on Oakcrest Street to the Casper Golf Course. The photopoint is southwest of the clubhouse on a man-made hill, which lies between the rifle range and golf course. The photo is taken toward the city of Casper. A water tank also helps locate the bench.

\section{Description}

September 8, 1999

\section{Between Fairways and Around Pond}

Grasses. Agropyron

intermedium, Agropyron cristatum, Agropyron smithii, Bouteloua gracilis, Stipa comata

\section{Synopsis}

A golf course now occupies this site. The city of Casper can be seen in the distance. In the immediate foreground of the 1998 photo is Agropyron intermedium, which dominates much of the area around the golf course fairways.

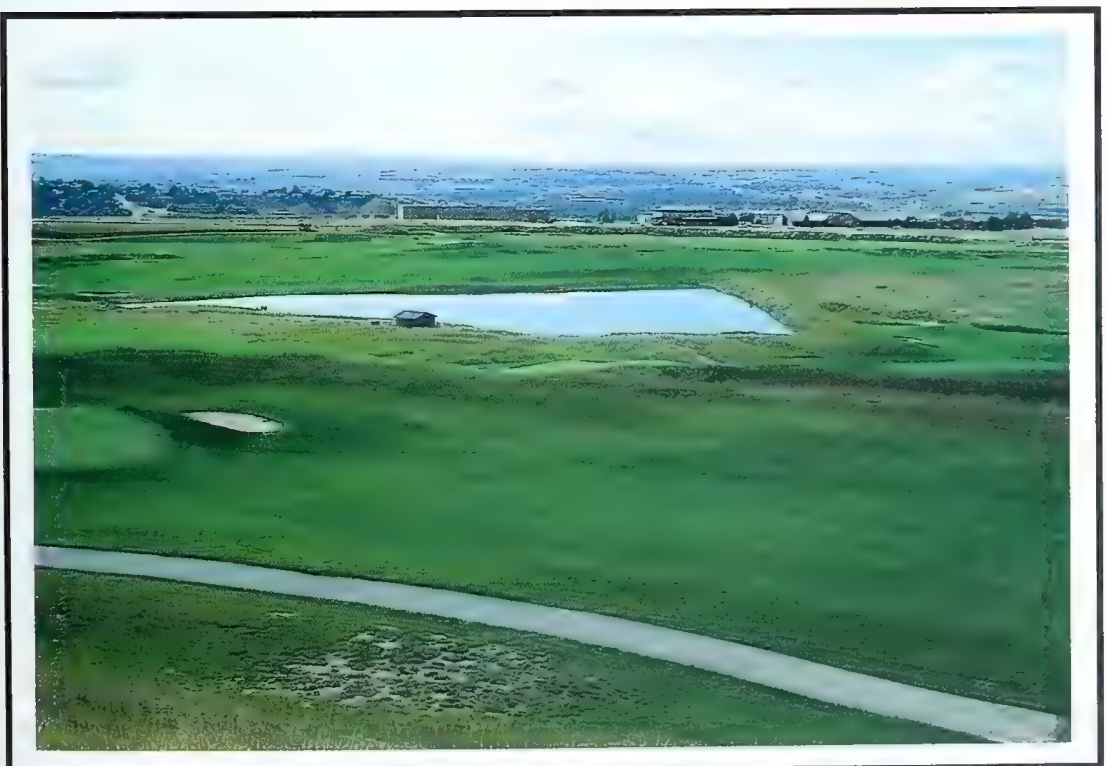




\section{Original Photograph}

August 21, 1916. Shantz N-2-1916. Facing south.

\section{First Retake and Description}

July 7, 1959. W.S.P., J-9-1959.

The original picture has much Artemisia spp. and Koeleria cristata. In the retake the Artemisia has lessened and there is more grass covering. Koeleria cristata is abundant and also Stipa comata (from Phillips 1963, p. 157).

Second Retake

August 4, 1998. Kay-4360-5.
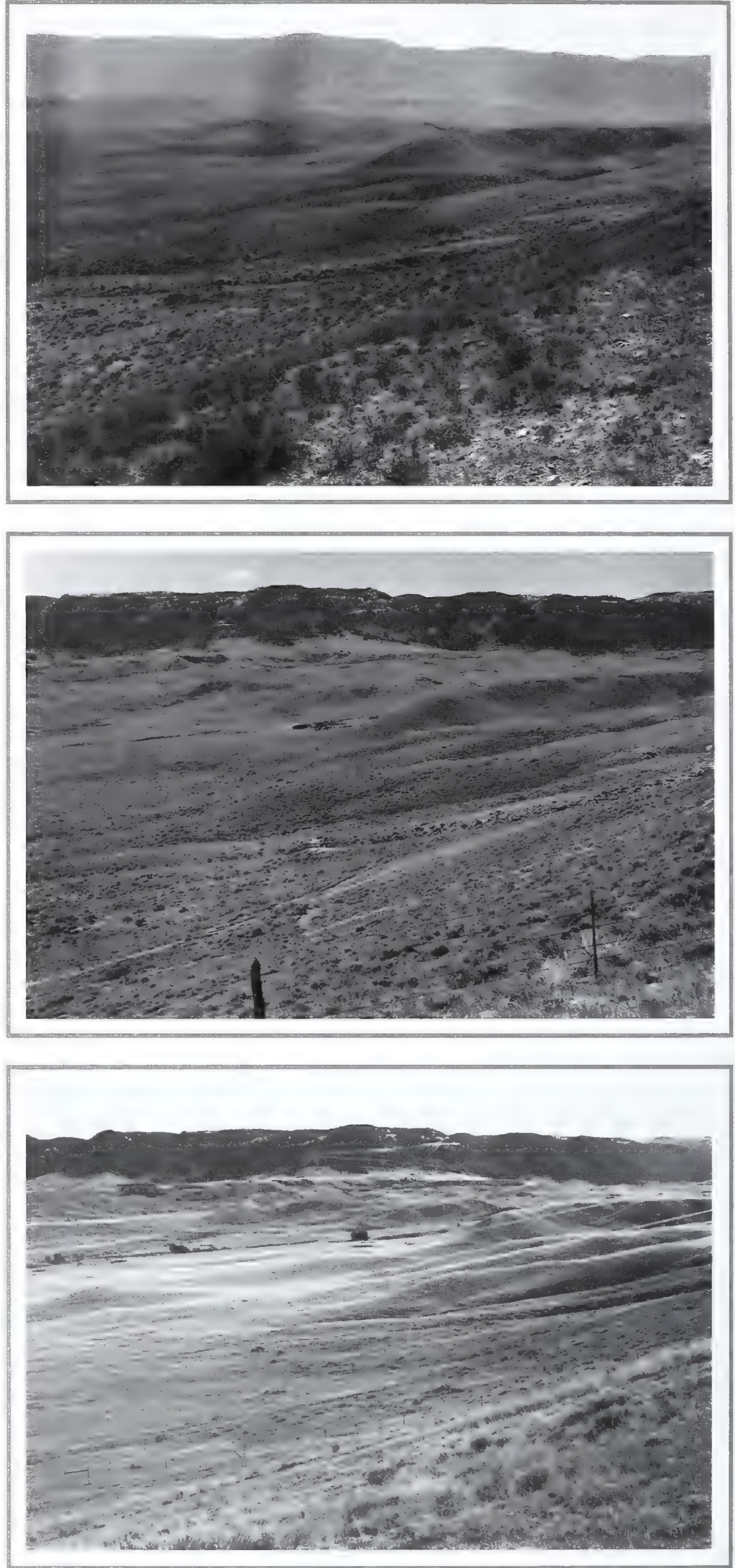


\section{Casper, Wyoming}

\section{Location}

Johnson Co., WY; Sec. 16, R. 79 W., T. 33 N.; GPS-UTM 4741934 N, 391986 E.

About 4 miles southeast of Casper.

Exit U.S. Interstate 25, 2 miles south of Casper onto Wyoming Highway 258 (south loop of Casper). Continue on south loop until Walcott Street. Then turn left (east) and continue to the public golf course. This photopoint is south of the photopoint for the previous site (pages 70 and 71 ).

\section{Description}

September 8, 1999

\section{Uplands and Hills}

Grasses. Carex filifolia,

Koeleria pyramidata, Agro-

pyron smithii, Stipa comata,

Bouteloua gracilis, Agropy-

ron intermedium
Shrubs. Artemisia tridentata, Artemisia frigida, Gutierrezia sarothrae, Yucca glauca

\section{Drainage}

Trees. Populus deltoides

\section{Synopsis}

Grass density has increased significantly since 1916. A few plants of Populus deltoides have become apparent in a drainage near the center between 1959 and 1998. Conifer species, predominantly Pinus ponderosa, have increased on the mountain. Two species, Agropyron intermedium and Agropyron cristatum, which were seeded along the edge of a golf course near this site, are now invading the site.

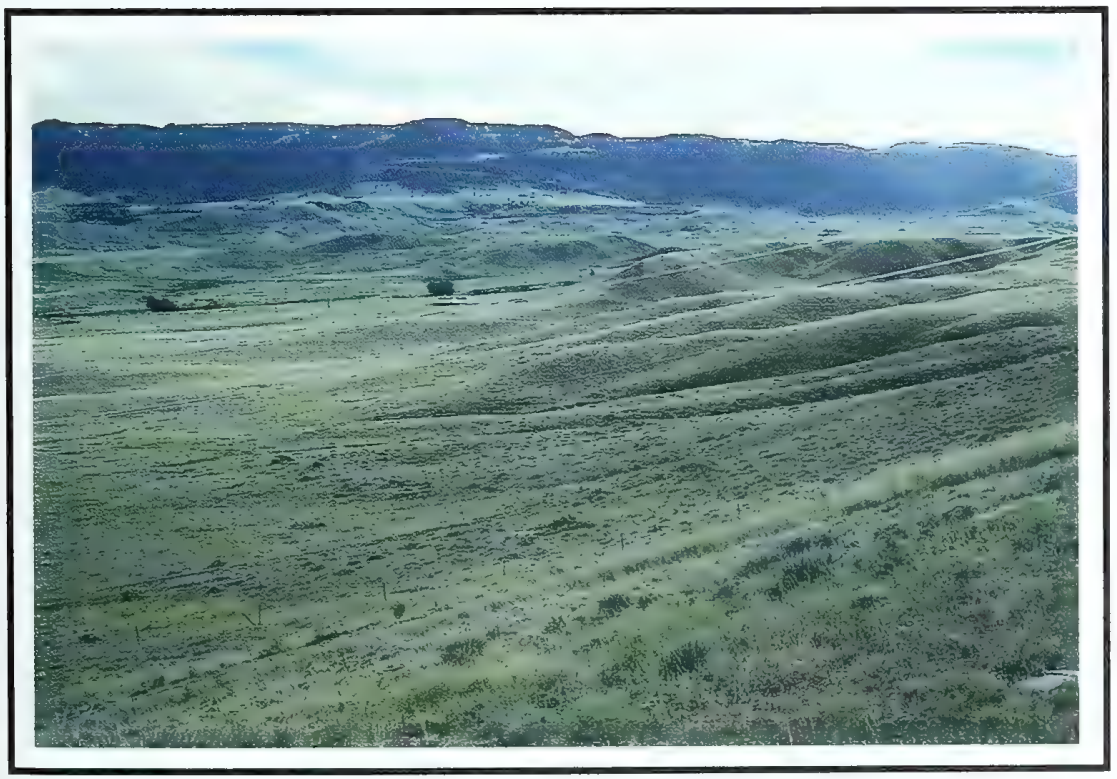




\section{Original Photograph}

August 21, 1916. Shantz N-5-1916. Facing south.

\section{First Retake and Description}

July 7,1959 . W.S.P.,

J-10-1959.

The pines here consist of two species, Pinus ponderosa and Pinus flexilis. The grass is mainly Koeleria cristata and Carex filifolia. There has not been much change here. The same trees are present and very little reproduction. This is an open exposed ridge, exposed to high winds. At the time the picture was taken it was necessary to hold the tripod down (from Phillips 1963, p. 159).

\section{Second Retake}

August 4, 1998. Kay-4360-30.
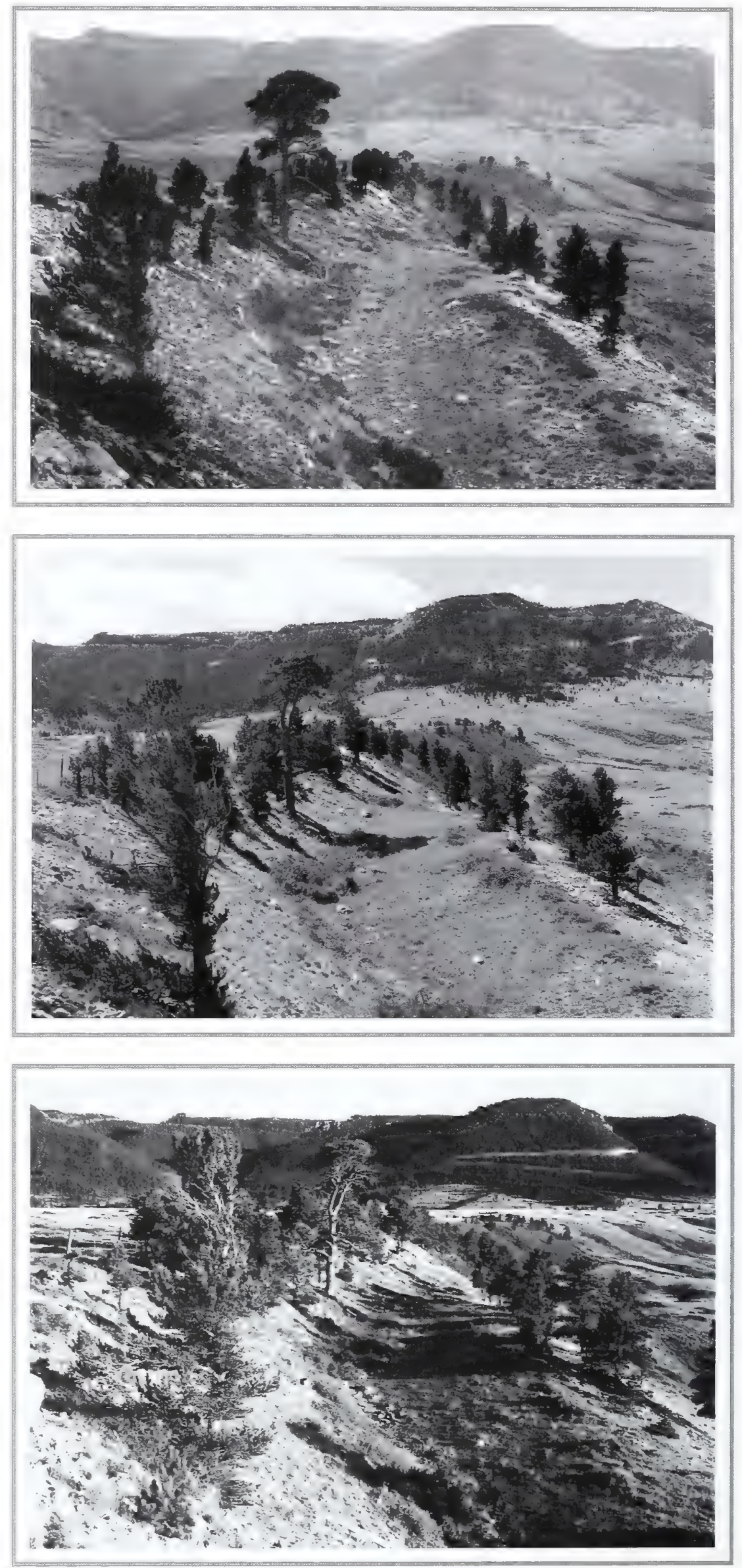


\section{Casper, Wyoming}

\section{Location}

Johnson, Co., WY; Sec. 33, R. 79 W., T. 33 N.; GPS-UTM 4738179 N, 391942 E.

About 5 miles south of Casper.

From Exit 185 on U.S. Interstate 25, travel south and then turn right (east) on Wyoming Boulevard (Wyoming Highway 258). Continue about 4.5 miles, then turn left (south) onto an unnamed gravel road (about 0.8 mile east of Wyoming County Road 510). Proceed about 1.5 miles to ranch headquarters. Photopoint is on top of ridge about 550 yards southwest of ranch house.

\section{Description}

September 9, 1999

\section{Ridgetop and Slope}

Grasses. Agropyron spicatum, Koeleria pyramidata, Agropyron smithii, Stipa comata

\section{Shrubs and Trees.}

Cercocarpus montanus, Rhus trilobata, Pinus ponderosa, Pinus flexilis

\section{Upland}

Grasses. Carex filifolia, Agropyron smithii, Koeleria pyramidata, Stipa comata

Shrubs and Trees. Artemisia tridentata, Rhus trilobata

\section{Synopsis}

The size and abundance of conifers and shrubs have increased significantly both along the ridge in the foreground and on the mountain in the distance. Other species appear to have changed little over the past 82 years.

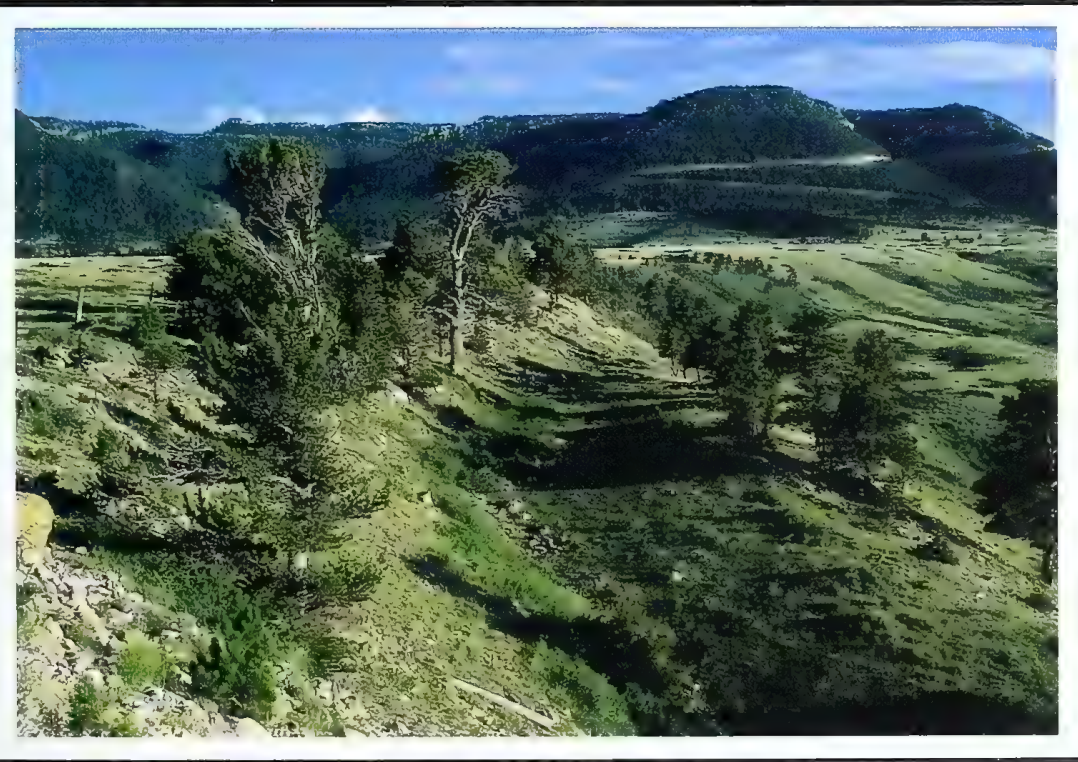




\section{Original Photograph}

September 1, 1937.

Shantz P-2-1937.

Facing east.

\section{First Retake and Description}

August 14, 1960. W.S.P., No. 2402.

This original picture was evidently taken from low road along side of the old road which has been completely dug out as a gravel pit for regrading the road. The original cover as described by Dr. Shantz consisted of Stipa comata, Poa spp.,

Koeleria cristata, Opuntia polycantha, and Artemisia frigida. These plants are still in evidence, but the grazing is much more intense and the Artemisia is more predominant in the later picture (from Phillips 1963, p. 161).
Second Retake

July 26, 1998.

Kay-4342-12A.
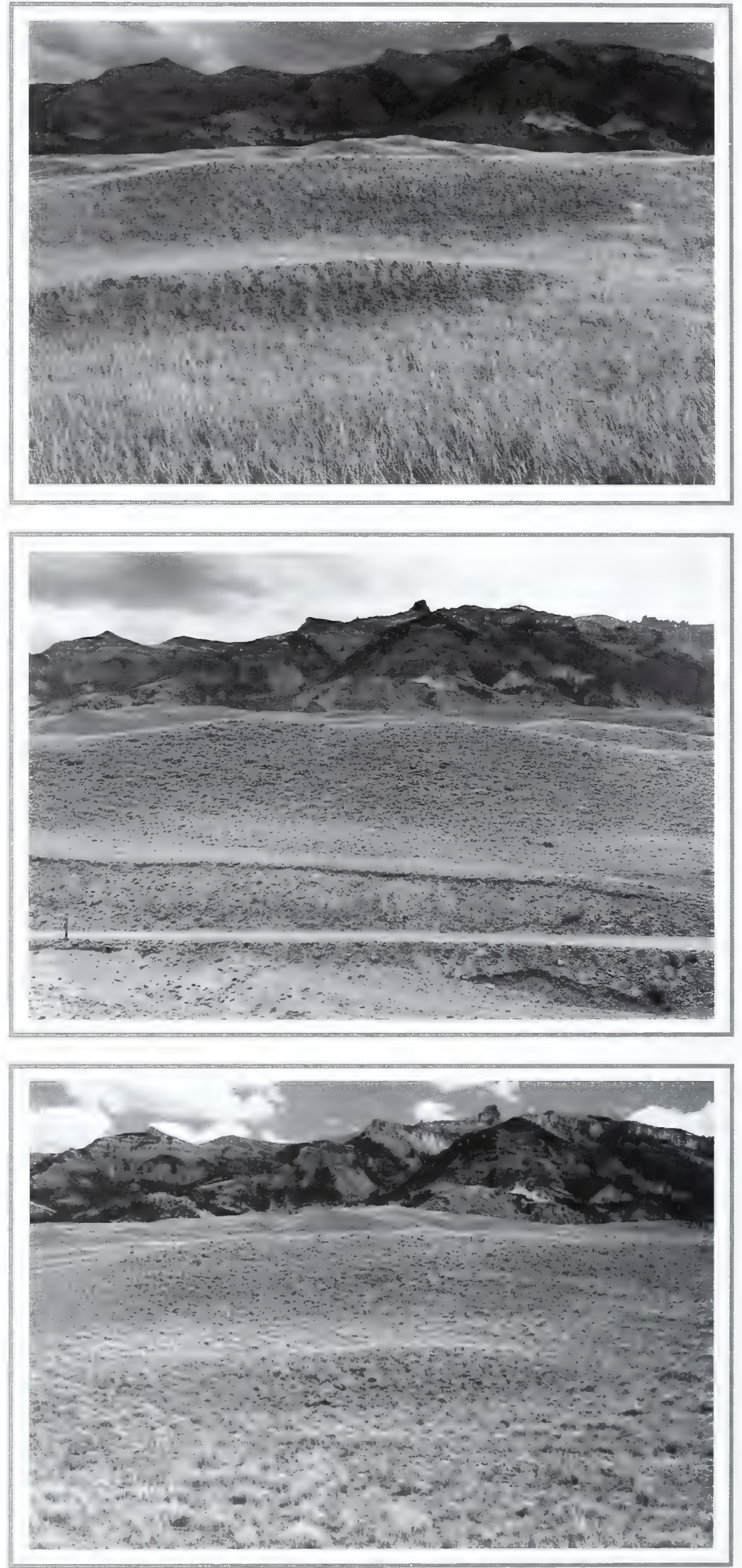


\section{Cody, Wyoming}

\section{Location}

Park Co., WY; Sec. 34, R. 105 W., T. 50 N.; GPS-UTM 4902330 N, 621115 E for 1937 and 1998 photopoint, and GPS-UTM 4902032 N, 620976 E for 1960 photopoint.

About 30 miles southwest of Cody.

From Cody, travel west on U.S. Highway 14 through town to Wyoming Highway 291. Continue southwest on Wyoming Highway 291, along the south fork of the Shoshoni River, for about 29 miles to the entrance of Shoshoni National Forest.

This set of photos was taken from two photopoints. The original (1937) and second retake (1998) were taken from the same photopoint, about 50 yards south of the north entrance on the east side of Wyoming Highway 291. The photopoint for the 1960 photo was taken on the west side of Wyoming Highway 291 about 50 yards south.

\section{Description}

September 10, 1999

\section{Upland to Mountain}

Grasses. Agropyron spicatum, Stipa comata, Koeleria pyramidata
Forbs. Opuntia polycantha

Shrubs and Trees. Artemisia frigida, Artemisia tridentata

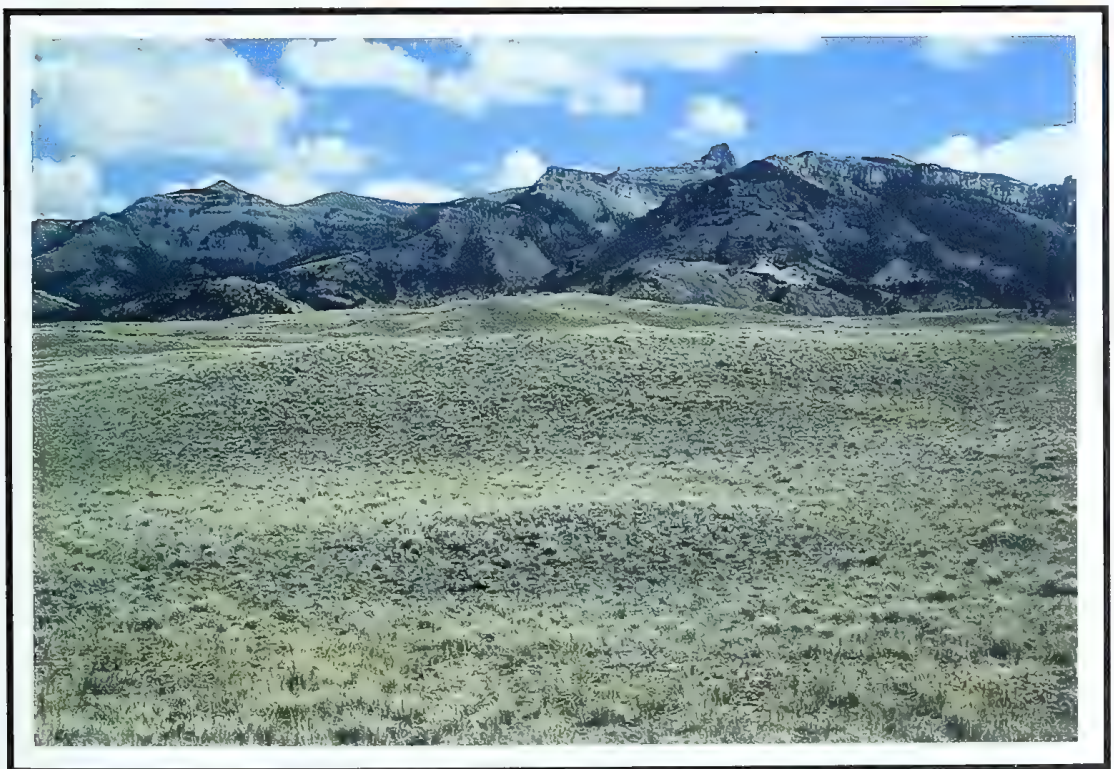

\section{Synopsis}

All three photos indicate little change has occurred in herbaceous cover, production, and species composition over time, with only a slight increase in conifer density (Pinus ponderosa) on the mountains 


\section{Original Photograph}

July 24, 1927. Reproduced black and white slide; Shantz BB-8-1927 missing. Facing west.

\section{First Retake and Description}

July 4, 1959. W.S.P., I-1-1959.

Very little difference in these two pictures. The Pinus ponderosa on the mountains has thickened up somewhat. The grasses mainly Stipa spp. about the same in both pictures, with the exception of where fill has covered grass. Artemisia spp. in bottomland similar and the cottonwoods along seep bank are the same (from Phillips 1963, p. 163).

\section{Second Retake}

July 26, 1998.

Kay-4342-7A.
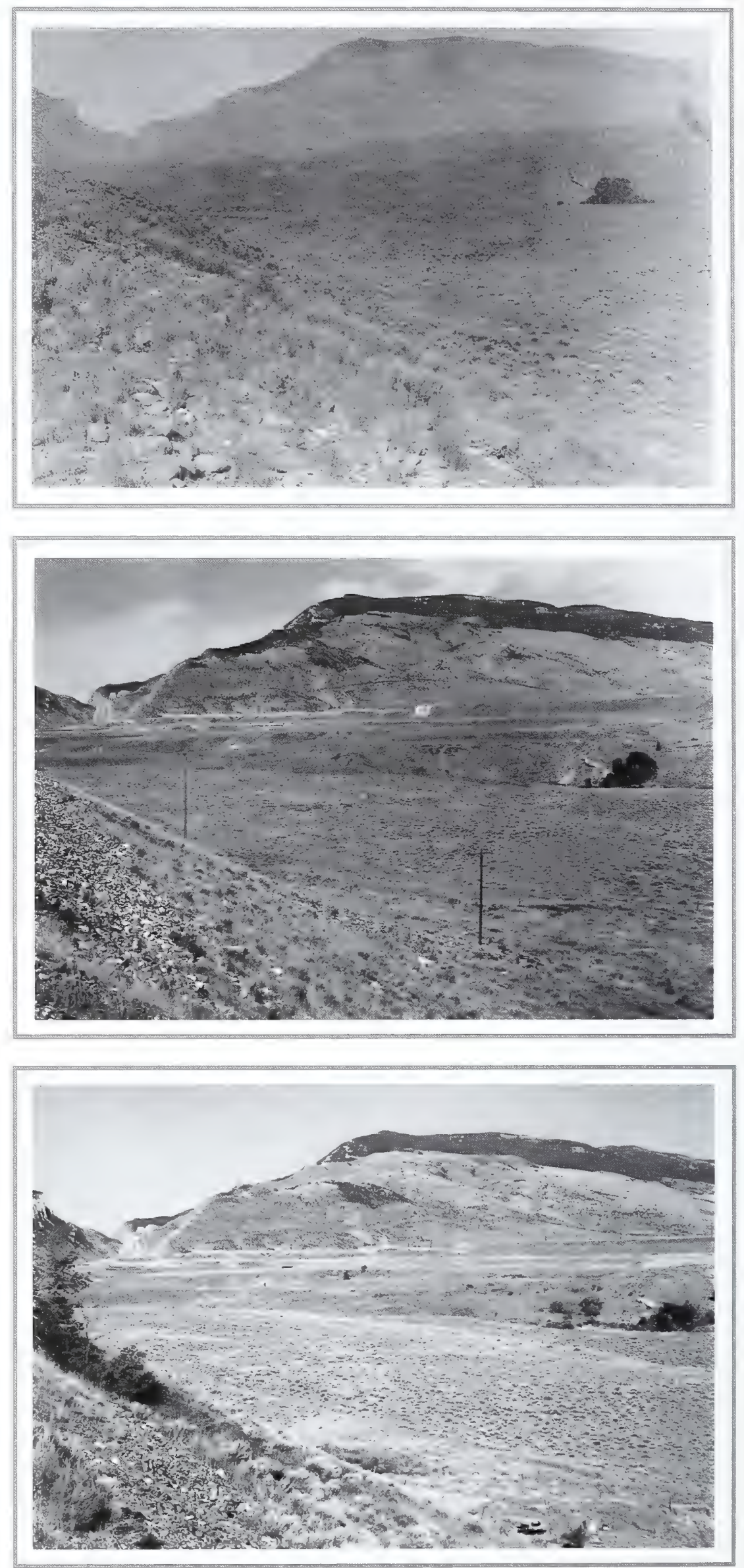


\section{Cody, Wyoming}

\section{Location}

Park Co., WY; Sec. 31, R. 101 W., T. 53 N; GPS-UTM 4932199 N, 652897 E.

North side of Buffalo Bill Museum in Cody.

From Cody, travel west on U.S. Highway 14 until reaching the Buffalo Bill Museum. The photopoint is north of the museum and about 30 yards west of the Buffalo Bill statue.

\section{Description}

September 10, 1999

\section{Uplands to Mountain}

Grasses. Agropyron cristatum, Agropyron spicatum, Bouteloua gracilis
Shrubs and Trees. Artemisia frigida, Chrysothamnus viscidiflorus, Artemisia tridentata, Shepherdia argentea, Fraxinus pennsylvanica, Populus deltoides

\section{Synopsis}

Very little change is apparent in the retaken photographs. The original photopoint has been disturbed slightly due to development on the hillside near the Buffalo Bill monument. An electric line has been gone since 1959. Melilotus officinalis and Agropyron cristatum have invaded the disturbed hillside in the foreground. As for mountain vegetation, there has been a minor increase in conifer density in some areas but a larger reduction near the left center of the photo. The "C" in the middle of the picture (representing the town of Cody) can be seen as early as 1959 .

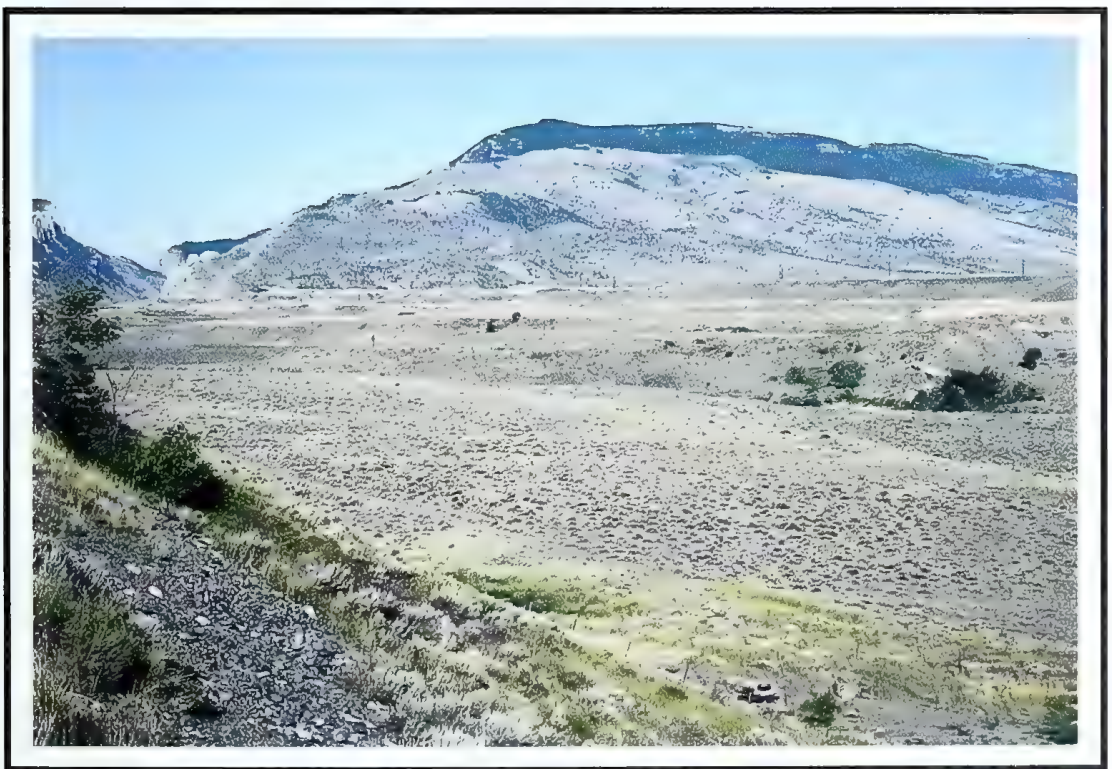




\section{Original Photograph}

September 27, 1917.

Shantz S-1 1-1917.

Facing southeast.

\section{First Retake and Description}

July 5, 1959. W.S.P., I-1 1-1959.

These two pictures are remarkably alike in spite of some forty years difference in time. The modern county highway has been wellgraded. Also original highway (note old Ford [above]) followed the contours of the land. The scar is still visible in the new picture. This was taken about three tenths of a mile from ranch house along main road (from Phillips 1963, p. 167).

\section{Second Retake}

July 27, 1998.

Kay-4346-7A.
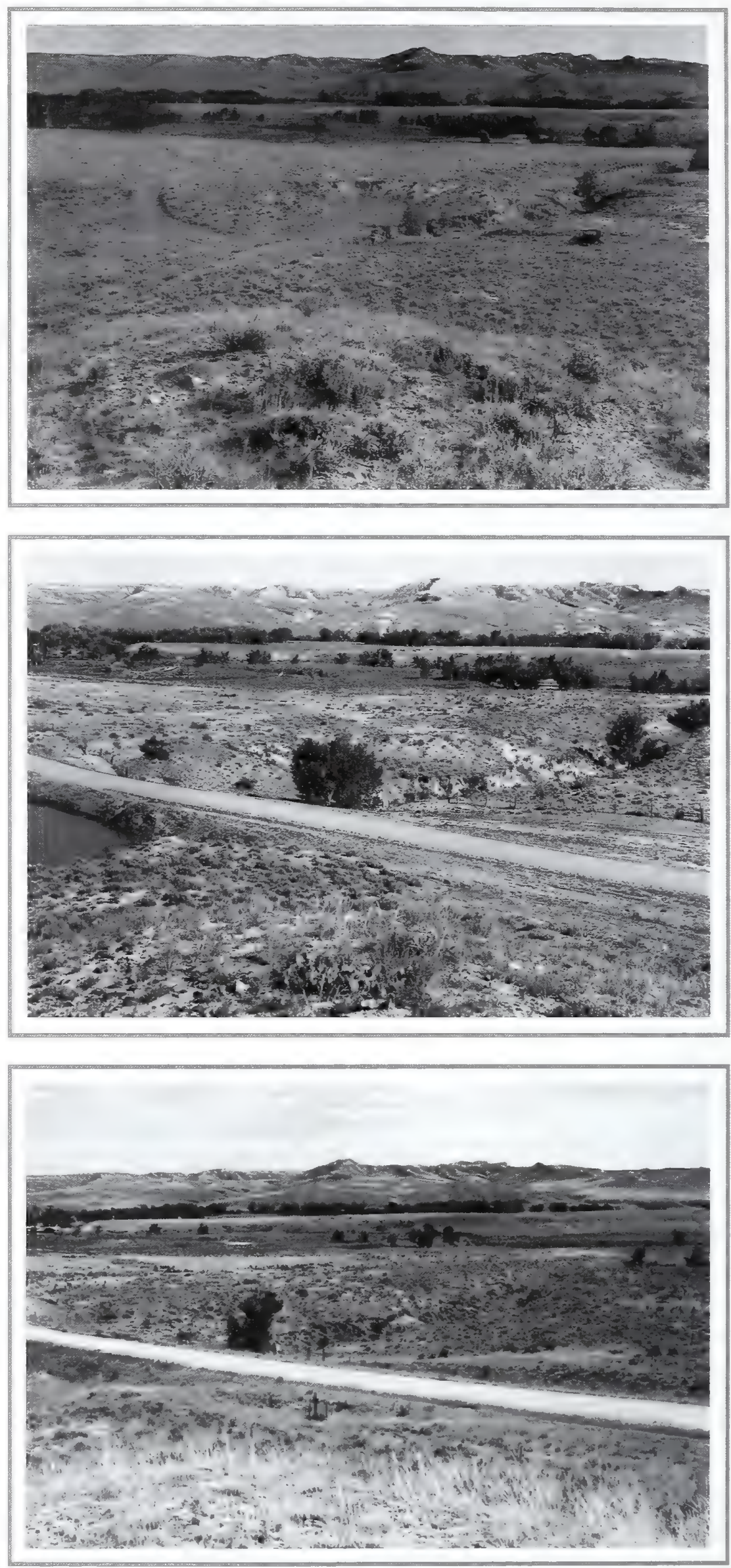


\section{Crazy Woman Creek, Wyoming}

\section{Location}

Johnson Co., WY; Sec. 8, R. 79 W., T. 51 N; GPS-UTM 4917608 N, 390112 E.

About 20 miles southeast of Buffalo.

Upon exiting U.S. Interstate 25 at Buffalo, travel east on the main road before turning right onto county road TW. Continue southeast 8.4 miles to Tipperary Road before turning left (northeast) onto a secondary road. Continue northeast for 15 miles. Photopoint is on hill 50 yards north of road.

\section{Description}

September 8, 1999

\section{Photopoint to Road}

Grasses. Poa secunda, Agropyron spicatum, Agropyron smithii, Bromus japonicus, Carex filifolia

Shrubs. Sarcobatus vermiculatus, Artemisia tridentata

\section{Beyond Road}

Grasses. Agropyron smithii, Poa secunda, Bromus japonicus, Bromus tectorum, Bouteloua gracilis, Buchloe dactyloides

\section{Shrubs and Trees.}

Sarcobatus vermiculatus, Artemisia tridentata, Populus deltoides

\section{Synopsis}

In the 1917 photo, an old road is visible and more sagebrush is growing in the foreground than in more recent photos. Populus deltoides trees present in 1917 showed a significant increase in size on both drainages until 1959. However, 1998 gave a significantly different result, with Populus deltoides density and size reducing in the closer drainage and very little change in the distant creek. By 1959, a more permanent gravel road was established, and a ponded area is visible on the left side of the photo. After 1959, a few more buildings were constructed. 


\section{Original Photograph}

September 26, 1917.

Shantz S-4-1917.

Facing northwest.

\section{First Retake and Description}

July 5, 1959. W.S.P., I-4-1959.

In almost the center of the original picture [above] is the Massacre Hill Monument, whereas in the new picture it is off to the right of the main road and has a gravel road leading up to it. The vegetation of this picture is almost exactly the same as S-2-1917 [see page 84] (from Phillips 1963, p. 177).

\section{Second Retake}

July 27, 1998.

Kay-4344-10.
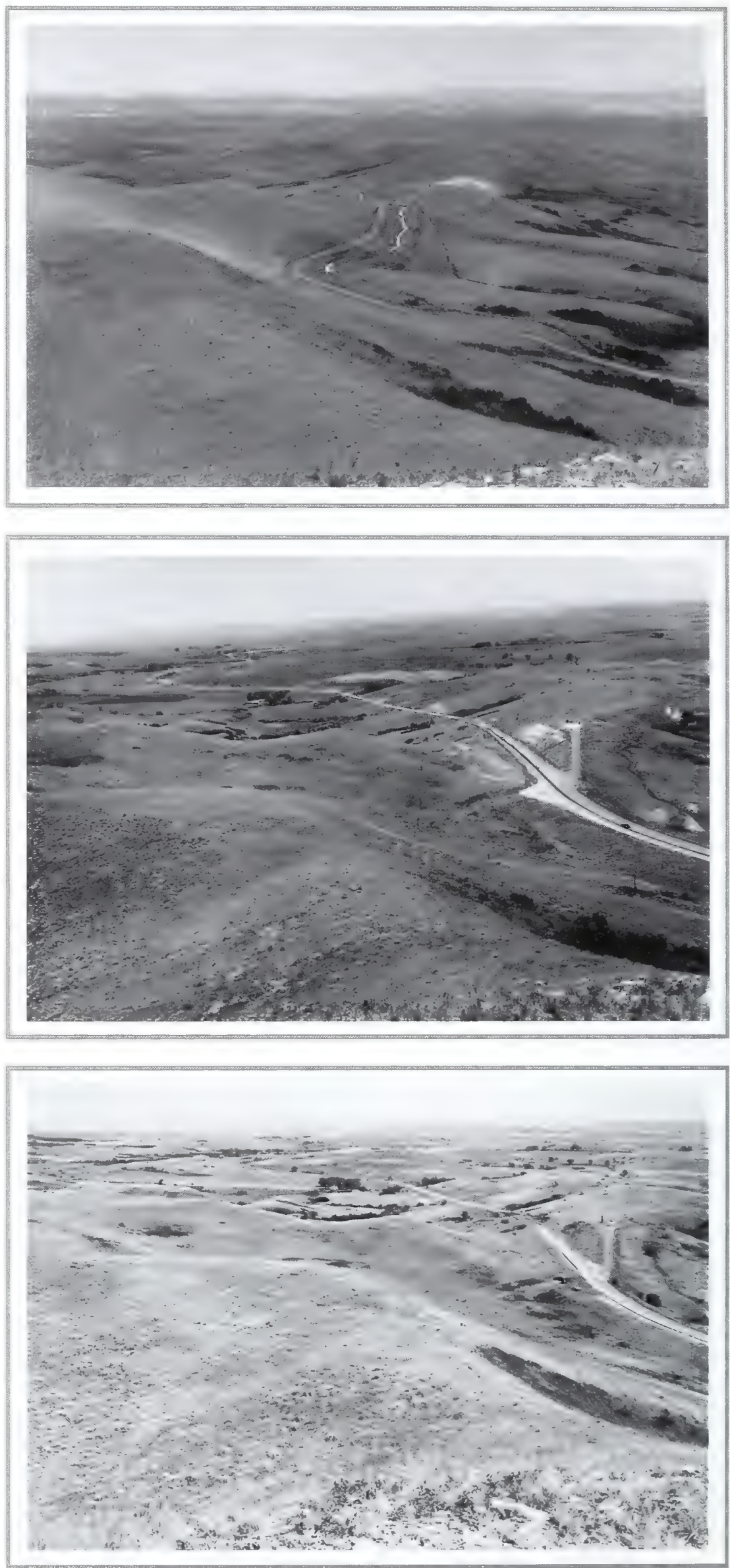


\section{Story, Wyoming}

\section{Location}

Sheridan Co., WY; Sec. 15, R. 83 W., T. 53 N.; GPS-UTM 4936150 N, 353906 E.

About 3 miles east of Story.

From Buffalo, Wyoming, travel north on U.S. Interstate 90 to Exit 44. Travel northwest on U.S. Highway 87/Wyoming Highway 344 about 5 miles to Massacre Hill Monument, site of Fetterman Massacre. Photopoint is on the large hill about 0.5 mile southwest of the monument.

\section{Description}

September 8, 1999

\section{Uplands}

Grasses. Agropyron smithii, Stipa comata, Koeleria pyramidata, Poa pratensis, Poa secunda, Agropyron spicatum

Shrubs. Artemisia frigida, Gutierrezia sarothrae

\section{Roadside}

Grasses. Bromus inermis, Agropyron intermedium. Sporobolus cryptandrus, Agropyron smithii, Bromus japonicus

Shrubs. Artemisia cana

\section{Bottomlands and Ridges}

Shrubs and Trees. Artemisia cana, Symphoricarpos occidentalis, Shepherdia argentea, Prunus virginiana, Salix spp., Fraxinus pennsylvanica, Populus tremuloides

\section{Synopsis}

Other than the landscaping from highway development (for example, note realignment of irrigation canal), the vegetation complex has changed very little over the past 80 years. The density and size of woody species appear to have increased slightly but nothing dramatic.

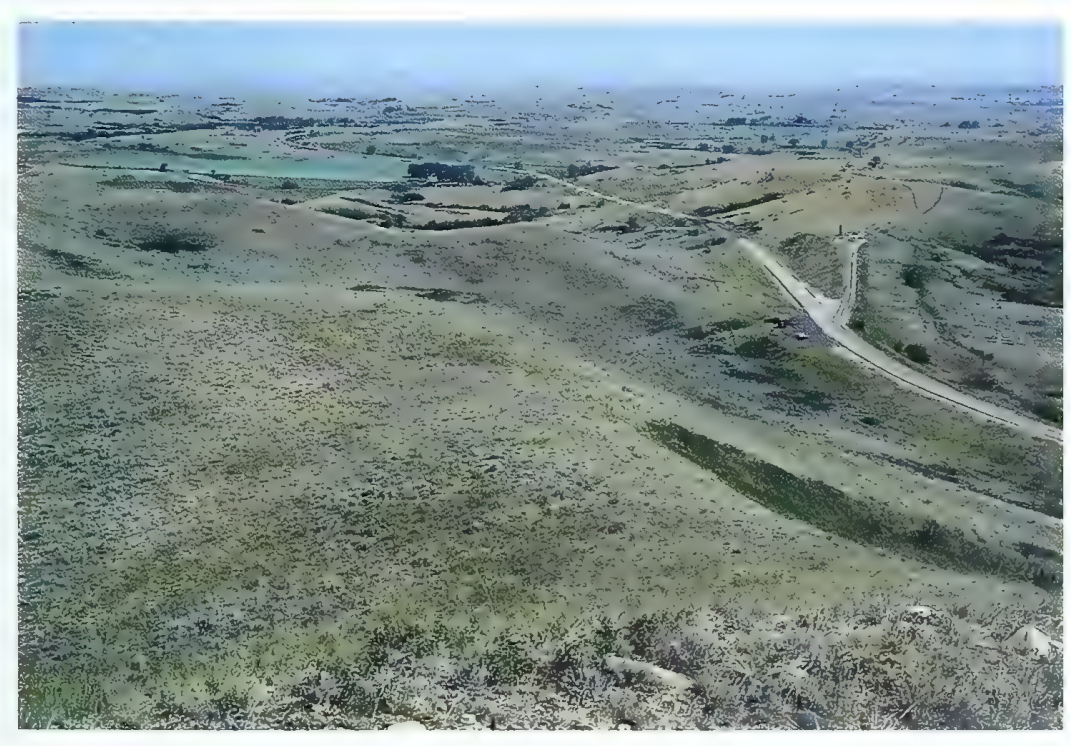




\section{Original Photograph}

September 26, 1917.

Shantz S-2-1917. Facing north-northeast.

\section{First Retake and Description}

July 5, 1959. W.S.P.,

I-2-1959.

Dr. Shantz took a panorama from the top of this hill, which has a surveyor's bench mark on it. Only two of these panoramic sets of pictures are included in this report. The grass in the original picture was

Bouteloua gracilis, along with much Carex filifolia. The dark shrub is Rhus spp., and the light colored shrub in the grass is Artemisia spp. In the retake, the same plants are still present and there is not too much change. The Rhus seems to have lessened and the Artemisia increased (from Phillips 1963, p.179).
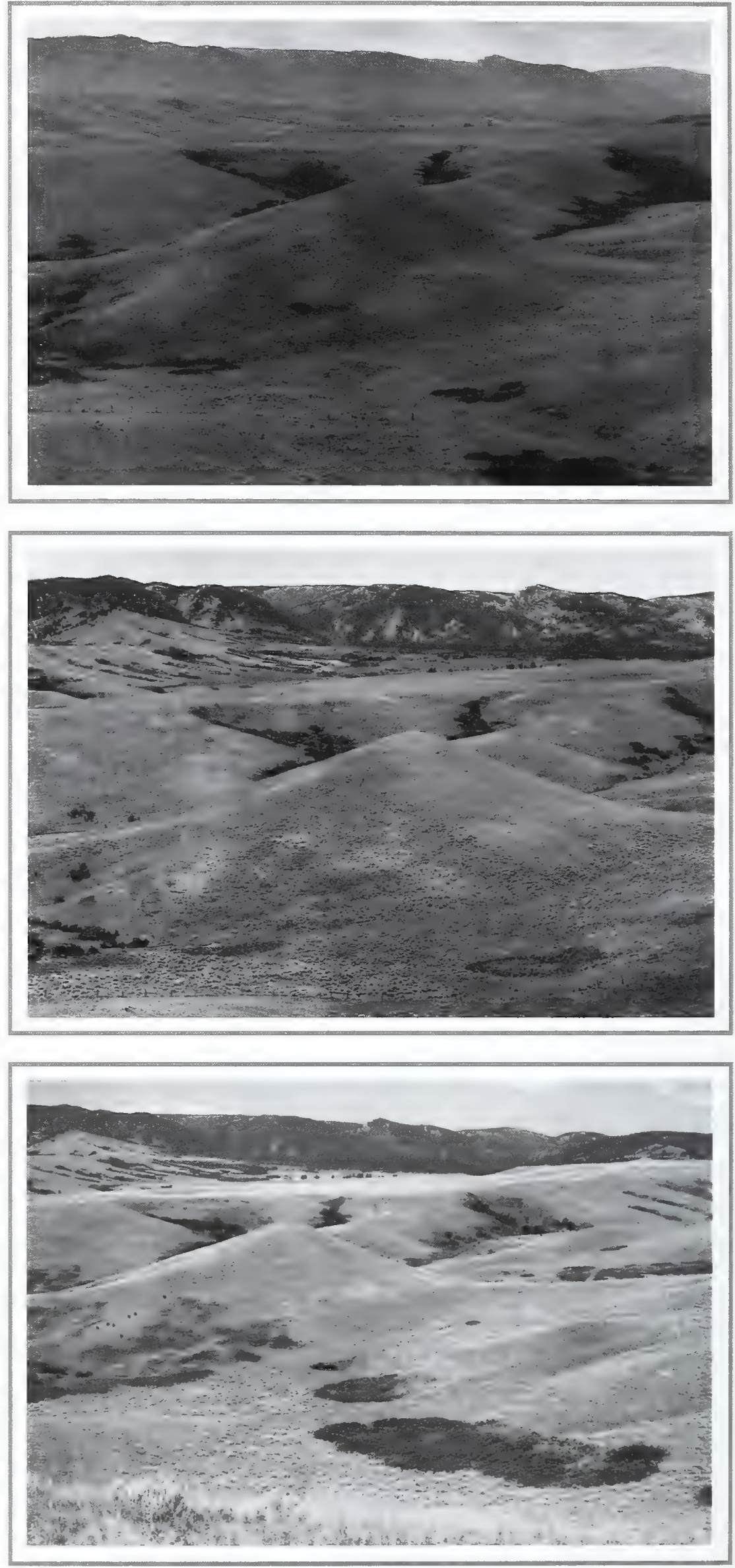


\section{Story, Wyoming}

\section{Location}

Sheridan Co., WY; Sec. 15, R. 83 W., T. 53 N.; GPS-UTM 4936150 N, 353906 E.

About 3 miles east of Story.

From Buffalo, Wyoming, travel north on U.S. Interstate 90 to Exit 44. Travel northwest on U.S. Highway 87/Wyoming Highway 344 about 5 miles to Massacre Hill Monument, site of Fetterman Massacre. Photopoint is on the large hill about 0.5 mile southwest of the monument.

\section{Description}

September 8, 1999

\section{Uplands and Hills}

Grasses. Agropyron smithii, Agropyron spicatum, Stipa comata, Koeleria pyramidata, Poa pratensis, Poa secunda, Agropyron spicatum

Shrubs. Artemisia frigida, Gutierrezia sarothrae

\section{Bottomland}

Shrubs and Trees. Artemisia cana, Artemisia tridentata, Symphoricarpos occidentalis, Shepherdia argentea, Prunus virginiana, Rhus trilobata

\section{Synopsis}

Rhus trilobata and

Symphoricarpos occidentalis stands continue to increase in size, as does the density of Artemisia tridentata and A. cana plants in the bottomlands. Cover of Pinus ponderosa has increased significantly on the Bighorn Mountains in the background. A livestock watering facility, located near the center of the photo, has been added since 1959.

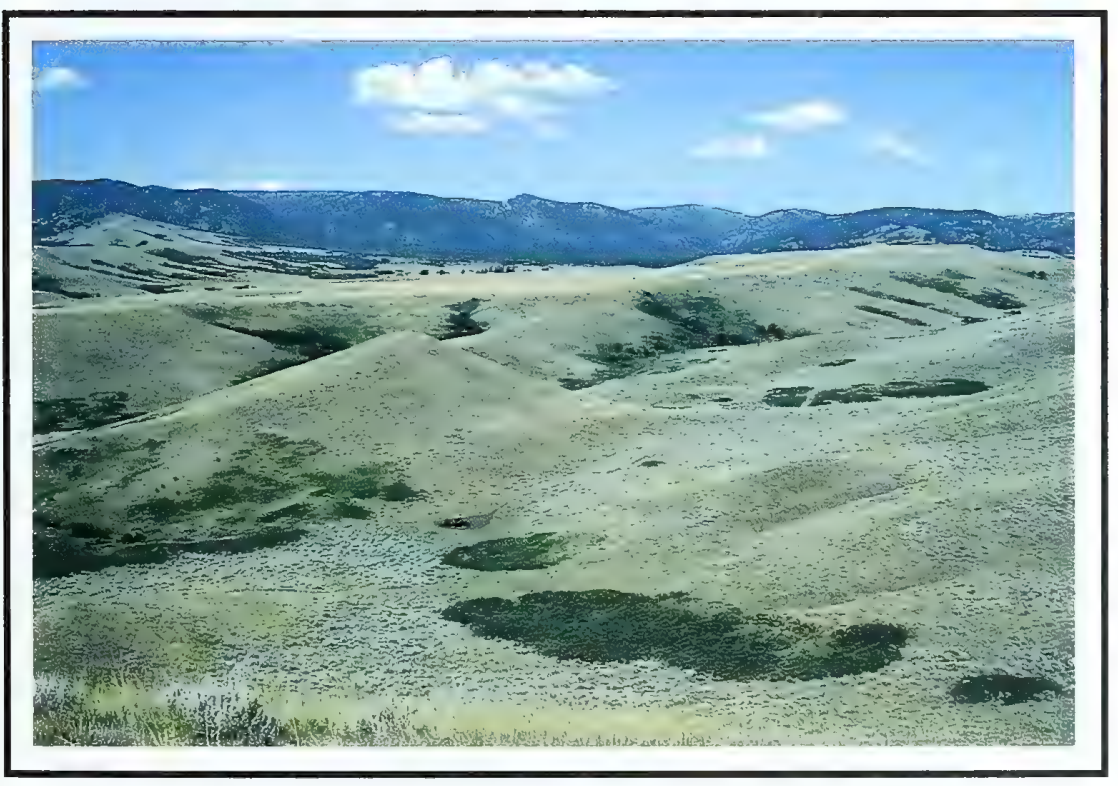




\section{Original Photograph}

August 22, 1916. Reproduced black and white slide: Shantz H-10-1916 missing. Facing northwest.

\section{First Retake and Description}

July 6, 1959. W.S.P., J-3-1959.

The highway and the railroad are on opposite banks of the river in the canyon so that this retake is not in the exact location. However, it is one of the few pictures that actually show some geological change. A large section of the central bluff has caved in and fallen down since the original picture was taken. The vegetation is about the same, and aside from the angle of the retake this picture matches very well (from Phillips 1963, p. 185).

\section{Second Retake}

August 5, 1998.

Kay-4360-36.
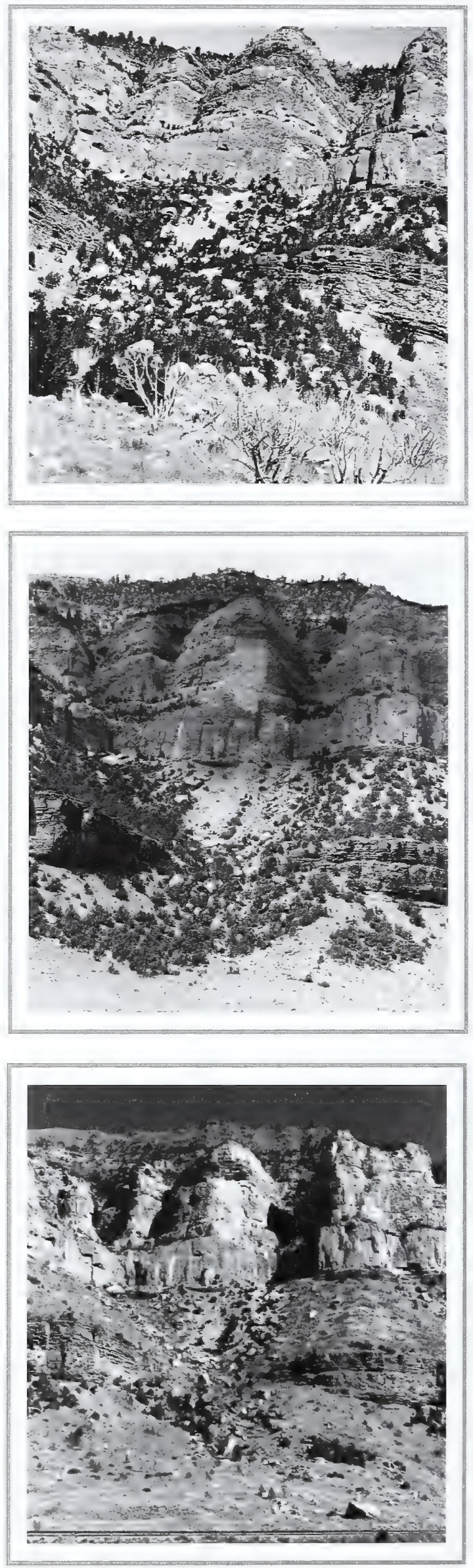


\section{Thermopolis, Wyoming}

\section{Location}

Hot Springs Co., WY; Sec. 21, R. 6 E., T. 6 N.; GPS-UTM 4818371 N 729042 E.

About 13 miles south of Thermopolis.

From Thermopolis, travel south about 13 miles on U.S. Highway 20 to milepost 119 . Original photo was taken from the railroad on the west side of the river. The retakes were taken on the east side of the river near the highway. Photopoint is within the Wind River Canyon and Wind River Indian Reservation.

\section{Description}

September 9, 1999

\section{Riverbanks}

Grasses. Phalaris arundinacea, Bromus inermis

Shrubs and Trees. Juniperus scopulorum

\section{Foothills and Bluff}

Grasses. Agropyron spicatum, Koeleria pyramidata, Poa secunda, Agropyron cristatum

\section{Shrubs and Trees.}

Juniperus scopulorum

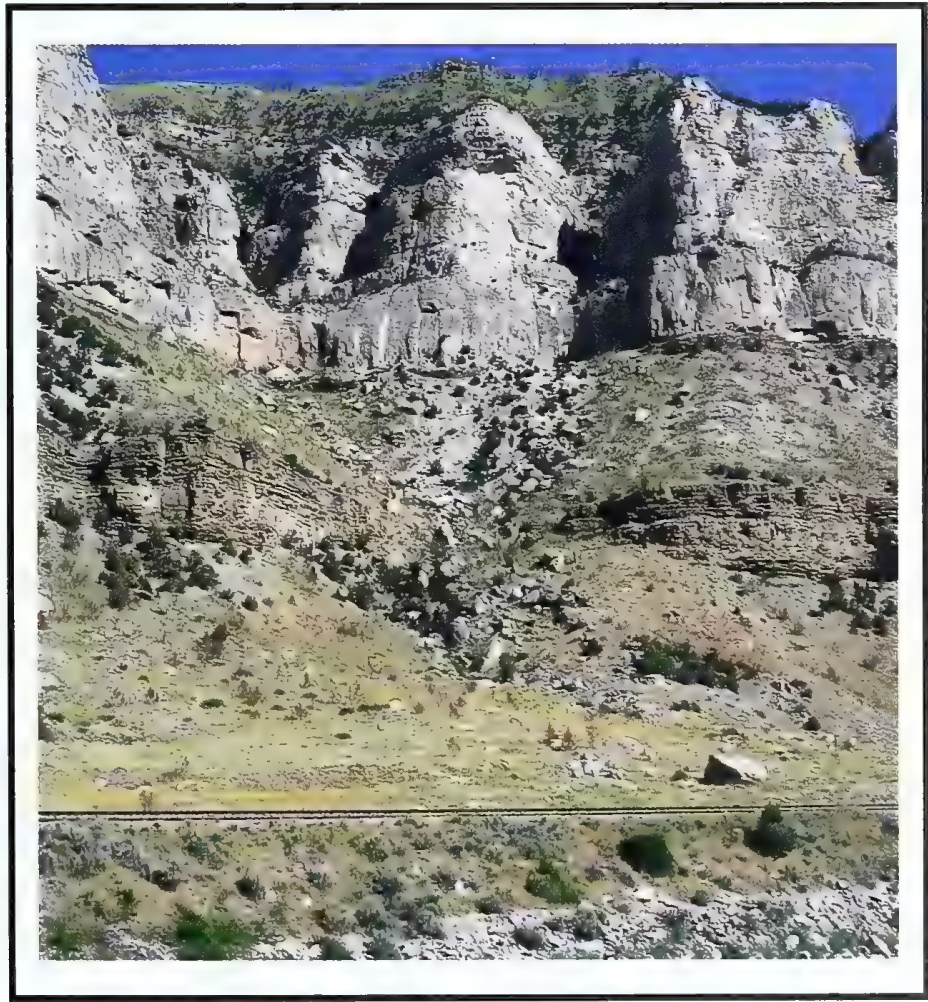

\section{Synopsis}

The geological changes that Phillips describes are very noticeable in the retakes. An additional rock slide occurred between 1959 and 1998 in the same area. There was also a fire on this site; notice the dead Juniperus scopulorum in the 1916 photograph. Fire scars can be found on many shrubs in the area. An increase in $J$. scopulorum is apparent in the 1998 retake. 


\section{Appendix 1. Plant Species, by Genus and Species and Common Name}

\section{Genus and Species}

\section{Grasses}

Agropyron cristatum (L.) Gaertn.

Agropyron intermedium Host. Beauv.

Agropyron smithii Rydb.

Agropyron spicatum (Pursh) Scribn. and Smith

Agropyron trachycaulum Link. Malta:

Andropogon gerardii Vitman

Andropogon hallii Hack.

Aristida pupurea var. longiseta (Steud.)

Bouteloua curtipendula (Michx.)

Bouteloua gracilis (H.B.K.) Lag. ex Griffiths

Bouteloua hirsuta Lag.

Bromus inermis Leyss.

Bromus japonicus Thunb. ex Murr.

Bromus tectorum L.

Buchloe dactyloides (Nutt.) Engelm.

Calamovilfa longifolia (Hook.) Scribn.

Carex filifolia Nutt.

Dichanthelium spp. (Hitch. \& Chase) Gould

Elymus canadensis L.

Hordeum jubatum L.

Hordeum vulgare $\mathrm{L}$.

Koeleria pyramidata (Lam.) Beauv.*

Muhlenbergia cuspidata (Torr.) Rydb.

Muhlenbergia racemosa (Michx.) B.S.P.

Oryzopsis hymenoides (R. \& S.) Ricker

Panicum virgatum $\mathrm{L}$.

Phalaris arundinacea L.

Phleum pratense $\mathrm{L}$.

Poa pratensis L.

Poa secunda Presl

Schizachyrium scoparium (Michx.) Nash. ${ }^{\dagger}$

Setaria spp. Beauv.

\section{Common Name}

Crested wheatgrass Intermediate wheatgrass

Western wheatgrass

Bluebunch wheatgrass

Slender wheatgrass

Big bluestem

Sand bluestem

Fendler three-awn

Side-oats grama

Blue grama

Hairy grama

Smooth brome

Japanese brome

Downy brome

Buffalograss

Prairie sandreed Threadleaf sedge

Dichanthelium

Canada wild rye

Foxtail barley

Barley

Junegrass

Plains muhly

Marsh muhly

Indian ricegrass

Switchgrass

Reed canarygrass

Timothy

Kentucky bluegrass

Sandberg's bluegrass

Little bluestem

Bristlegrass 


\section{Genus and Species}

Spartina pectinata Link

Sporobolus cryptandrus (Torr.) A. Gray

Stipa columbiana Macoun.

Stipa comata Trin. \& Rupr.

Stipa viridula Trin.

\section{Forbs}

Achillea millefolium L.

Allium reticulatum M. Ownbey

Allium canadense $L$.

Ambrosia trifida L.

Ambrosia psilostachya DC.

Artemisia ludoviciana Nutt. $\neq$

Asclepias spp. L.

Aster ericoides L.

Aster spp. L.

Bahia oppositifolia (Nutt.) DC.

Chrysopsis villosa (Pursh) Nutt.

Cirsium plattense (Rydb.) Cockll.

Comandra pallida (L.) Nutt.

Conyza canadensis (L.) Cronq.

Echinacea angustifolia DC.

Eriogonium spp. Michx.

Erysimum asperum (Nutt.) DC.

Grindelia squarrosa (Pursh) Dun.

Helianthus annuus L.

Kochia scoparia (L.) Schrad.

Lesquerella spp. S. Wats.

Liatris punctata Hook.

Medicago sativa L.

Melilotus officinalis (L.) Pall.

Opuntia polycantha Haw.

Paronychia jamesii T. \& G.

Phlox hoodii Rich.

\section{Common Name}

Prairie cordgrass

Sand dropseed

Columbia needlegrass

Needle-and-thread grass

Green needlegrass

$$
\begin{array}{r}
\text { Yarrow } \\
\text { Wild onion } \\
\text { Wild onion } \\
\text { Giant ragweed } \\
\text { Western ragweed } \\
\text { Cudweed sagewort } \\
\text { Milkweed } \\
\text { White aster } \\
\text { Wild aster } \\
\text { Bahia } \\
\text { Golden aster } \\
\text { Platte thistle } \\
\text { Comandra } \\
\text { Horse-weed } \\
\text { Purple coneflower } \\
\text { Wild buckwheat } \\
\text { Western wallflower } \\
\text { Curly-top gumweed } \\
\text { Common sunflower } \\
\text { Kochia } \\
\text { Bladderpod } \\
\text { Blazing-star } \\
\text { Alfalfa } \\
\text { Yellow sweetclover } \\
\text { Plains pricklypear } \\
\text { James' nailwort } \\
\text { Hood's phlox }
\end{array}
$$




\section{Genus and Species}

Plantago patagonica Jacq. §

Psoralea tenuiflora Pursh.

Rumex spp. L.

Selaginella densa Rydb.

Solidago spp. L.

Sphaeralcea coccinea (Pursh) Rydb.

Verbena spp. L.

Vicia americana Muhl. ex Willd.

Xanthium strumarium L.
Common Name

Patagonian plantain Scurfypea

Dock

Spikemoss

Goldenrod

Scarlet globemallow

Vervain

American vetch

Cocklebur

\section{Shrubs and Trees}

Acer negundo L.

Boxelder

Amelanchier alnifolia Nutt.

Artemisia cana Pursh.

Artemisia dracunculus L.

Artemisia filifolia Torr.

Artemisia frigida Willd.

Artemisia tridentata Nutt.

Atriplex nuttallii S. Wats.

Atriplex canescens (Pursh) Nutt.

Atriplex confertifolia (Torr. \& Frem.) S. Wats.

Ceratoides lanata (Pursh) Howell

Cercocarpus ledifolius Raf.

Chrysothamnus nauseosus (Pall.) Britt.

Chrysothamnus viscidiflorus (Nutt.) Hook.

Crataegus succulenta Link

Eleagnus angustifolia L.

Fraxinus pennsylvanica Marsh.

Gutierrezia sarothrae (Pursh) Britt. \& Rusby

Juniperus communis $\mathrm{L}$.

Juniperus horizontalis Moench

Juniperus scopulorum Sarg.

Juniperus virginiana $\mathrm{L}$.

Rocky Mountain juniper

Pinus ponderosa Laws.
Red cedar

Saskatoon serviceberry

Silver sagebrush

Silky wormwood

Sand sagebrush

Fringed sagewort

Big sagebrush

Nuttall saltbush

Four-wing saltbush

Spiny saltbush

Winterfat

Mountain mahogany

Rubber rabbitbrush

Green rabbitbrush

Succulent hawthorn

Russian olive

Green ash

Broom snakeweed

Common juniper

Creeping juniper

Ponderosa pine 


\section{Common Name}

\section{Shrubs and Trees}

Populus angustifolia James

Populus deltoides Marsh.

Populus tremuloides Michx.

Populus trichocarpa T. \& G.

Potentilla fruticosa $\mathrm{L}$.

Prunus virginiana $\mathrm{L}$.

Quercus stellata Wang.

Guercus macrocarpa Michx.

Rhus trilobata Nutt.

Rosa woodsii Lindl.

Salix exigua Nutt.

Sarcobatus vermiculatus (Hook.) Torr.

Shepherdia argentea (Pursh) Nutt.

Symphoricarpos albus (L.) Blake

Symphoricarpos occidentalis Hook.

Tetradymia canescens DC.

Ulmus americana L.

* Koeleria cristata Pers. in Phillips 1963.

+ Andropogon scoparius Michx. in Phillips 1963.

* Artemisia gnaphalodes Nutt. in Phillips 1963.

\& Plantago purshii R.\& S. in Phillips 1963.
Narrowleaf cottonwood

Cottonwood

Guaking aspen

Black cottonwood Shrubby cinquefoil

Chokecherry Post oak

Bur oak

Skunkbush sumac

Western wild rose Sandbar willow

Greasewood

Buffaloberry

White coralberry

Western snowberry

Gray horsebrush

American elm

Sources: Hitchcock 1950, Great Plains Flora Association 1986.

\section{References}

Great Plains Flora Association. 1986. Flora of the Great Plains. University Press of Kansas, Lawrence

Hitchcock, A.S. 1950. Manual of the Grasses of the United States. U.S. Department of Agriculture. USDA Miscellaneous Publication No. 200.

Phillips, W.S. Photographic Documentation: Vegetational Changes in Northern Great Plains. 1962. University of Arizona, Tucson, College of Agriculture. Agricultural Experiment Station Report No. 214. 


